Portland State University

PDXScholar

$5-14-1993$

\title{
William Smith Clark: A Study in Education, Christianity, and American-Japanese Cooperation in the Nineteenth Century
}

Brett L. Walker

Portland State University

Follow this and additional works at: https://pdxscholar.library.pdx.edu/open_access_etds

Part of the History Commons

Let us know how access to this document benefits you.

Recommended Citation

Walker, Brett L., "William Smith Clark: A Study in Education, Christianity, and American-Japanese Cooperation in the Nineteenth Century" (1993). Dissertations and Theses. Paper 4640.

https://doi.org/10.15760/etd.6524

This Thesis is brought to you for free and open access. It has been accepted for inclusion in Dissertations and Theses by an authorized administrator of PDXScholar. Please contact us if we can make this document more accessible: pdxscholar@pdx.edu. 
AN ABSTRACT OF THE THESIS OF Brett L. Walker for the Master of Arts in History presented May 14, 1993.

Title: William Smith Clark: A Study in Education, Christianity, and American - Japanese cooperation in the Nineteenth Century.

APPROVED BY THE MEMBERS OF THE THESIS COMMITTEE:
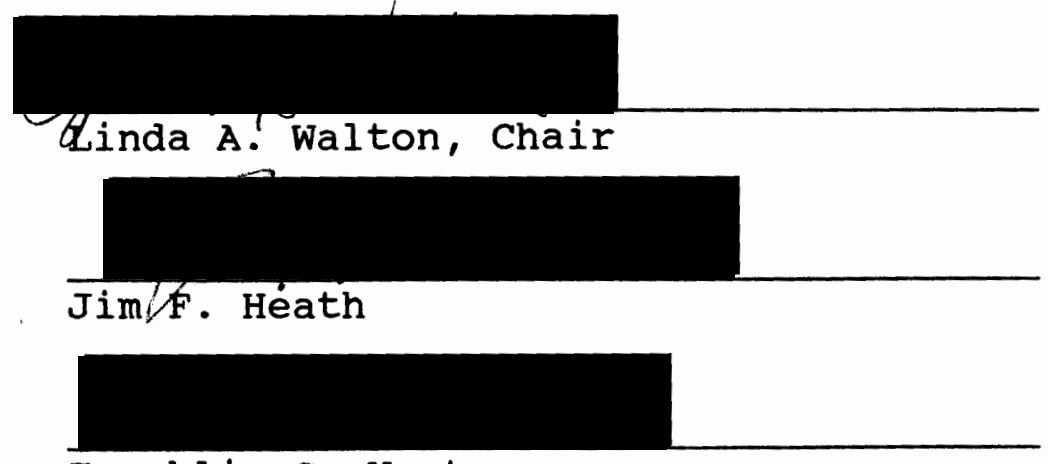

Franklin C. West



Gil Latz D

In March, 1990, I was hired to teach English in Japan at a small, private academy in Chitose, Hokkaido. The school was called the Academy of Clark's Spirit. My first day at work I was asked by my boss, Sato Masako: "So Mr. walker, of course you know who Dr. Clark is?"

I told Mr. Sato that I was sorry, but that I did not. "You said in your resume that you are a history student? We named this school after him. He's one of the 
most important people in Hokkaido's history," he said, looking disappointed.

Mr. Sato explained that he wanted me to teach with the spirit of clark in mind and bring to his classrooms what clark brought to Hokkaido over a hundred years before.

I nodded and asked to see my apartment.

I began this study of william Smith clark after my first stay in Hokkaido. It is the product of my interest in modern Japanese history, particularly Japan's relationship with the United States. The first leg of this project was started in Amherst, Massachusetts, where I met with Dr. John Maki. He directed me through the clark collection at the University of Massachusetts at Amherst. I had several interviews with Maki during the week I was in Massachusetts and was given liberal access to the clark collection under his influence.

The second leg of my study was continued in Sapporo, Hokkaido. I met with Dr. Toshiyuki Akizuki at Hokkaido University and was shown through the clark collection there. I lived in Hokkaido for about two years and have kept notes on the tribute paid to clark and visible signs of his impact on the northern island.

The focus of this study is to look at clark's contribution to the development of Hokkaido by detailing his work in education, Christianity, and agriculture. By 
focusing on clark's particular contribution to Hokkaido a larger historical trend, that is, the importation of foreign ideas in the history of Meiji Japan, is better understood. The results of this study conclude that clark was an important figure in the history of Hokkaido's settlement, and to the development of nineteenth century Japan., Clark was also an important figure in the history of the relations between Japan and the United States., It is in lasting institutions like Hokkaido University and the Sapporo Independent Christian Church where Clark's impact is best illustrated. These institutions, particularly the university, were the nerve centers for Hokkaido's development, and clark planted these seeds of enlightenment, under the direction of the Meiji government, in the fertile northern soil.

I have gained a better understanding of Clark's stay in Hokkaido because of this project, but doubt that I could even now satisfy Mr. Sato's insistence that I teach with clark's spirit. I do understand, however, why it was important to Mr. Sato that I try. Clark's phrase "Boys Be Ambitious" still embodies the spirit of many educators in Hokkaido and his success with Japanese students is one of the better examples of international exchange in any country. Clark is cherished by the people of Hokkaido as the spiritual pioneer of their island even though his stay 
lasted only eight months.

lasted only eight months. 
WILLIAM SMITH CLARK: A STUDY IN EDUCATION, CHRISTIANITY, AND AMERICAN - JAPANESE COOPERATION IN THE

NINETEENTH CENTURY

by

BRETT I. WALKER A thesis submitted in partial fulfillment of the
requirements for the degree of

\author{
MASTER OF ARTS \\ in \\ HISTORY
}

Portland State University

1993 
TO THE OFFICE OF GRADUATE STUDIES:

The members of the committee approve the thesis of Brett L. Walker presented May 14, 1993 .

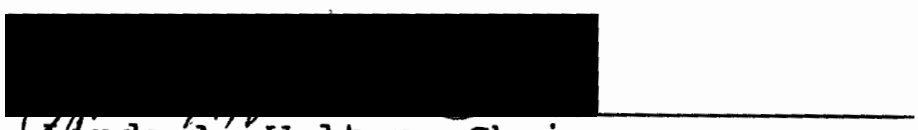

Ulinda A. Walton, Chair

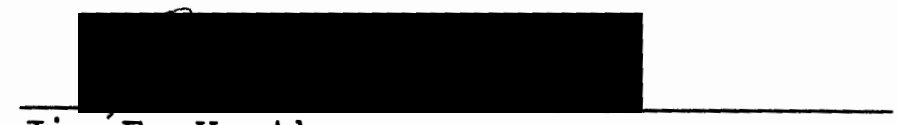

Jim F. Heath

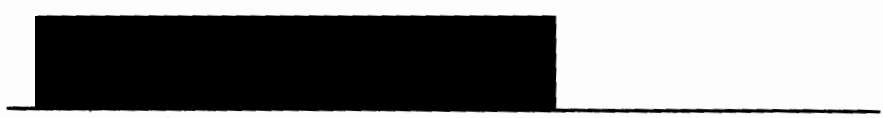

Franklin C. West
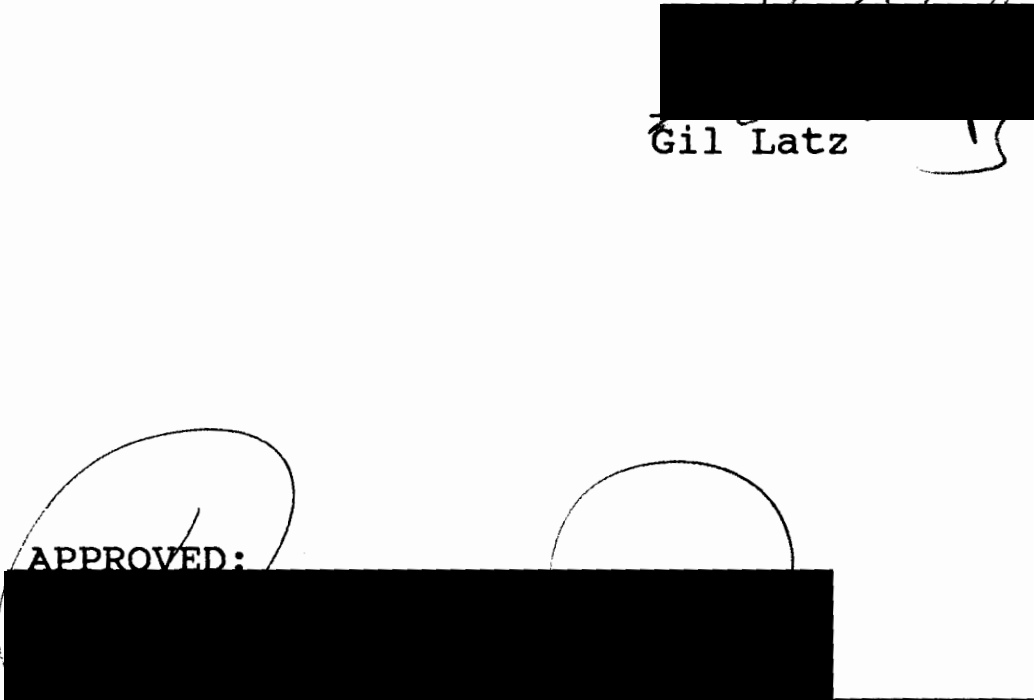

Bernard V. Burke, Chair, Department of History.

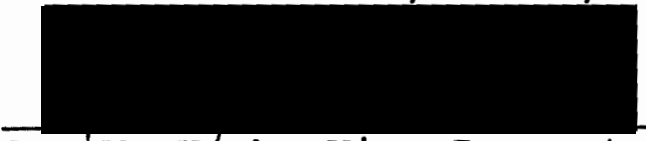

Roy W. K申ch, Vice Provost for Graduate Studies and Research. 


\section{ACKNOWLEDGEMENTS}

I am indebted to Yuka Hara Walker, Dr. Linda Walton, Dr. John Maki, Dr. Takeo Fukuda, and Dr. Toshiyuki Akizuki. Also, I am grateful to the University of Massachusetts and Hokkaido University libraries for granting me liberal access to material for this project. 
TABLE OF CONTENTS

PAGE

ACKNOWLEDGEMENTS........................... . . . . .

LIST OF FIGURES .......................... vii

CHAPTER

I INTRODUCTION....................... 1

II HOKKAIDO, THE KATTAKUSHI, AND KURODA KIYOTAKA.. 10 The Development of Hokkaido under the Meiji Government.....................11

Early attempts by the Meiji leadership to settle Ezo and the rise of Kuroda Kiyotaka........................ 16

Kuroda and the centralization of the Kaitakushi.................... 22

Kuroda and the Kaitakushi's policy on education....................... 30

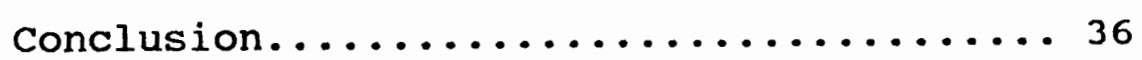

III THE PROCESS OF FINDING AN INSTRUCTOR AND THE EVENTS THAT LED TO THE CONTRACT BETWEEN CLARK AND THE KATTAKUSHI................ 40

The Search for clark............... 40

clark, his staff, and the contract signed......................... 47

Clark's early life in New England....... 51

The development of an academic........ 53

Establishing the foundations for practical and moral education in Hokkaido........ 58 
Conclusion...................... 61

IV THE ACCOMPLISHMENTS OF CLARK AS FOUNDER OF

THE SAPPORO AGRICULTURAL COLLEGE............ 64

The journey to Japan and initial

descriptions..................... 64

Clark's arrival in sapporo............ 70

The opening of the Sapporo Agricultural

College...................... 76

Clark takes over the sapporo experimental

farm........................ 80

The reorganization of the sapporo

experimental farm to better suit clark's

economy of agriculture..............83

The barn at the Sapporo Agricultural

College........................ 87

The introduction of stock, seed, and

implements to the farm............. 89

Proposed improvements to Hokkaido and the suggestion of an American settlement..... 90

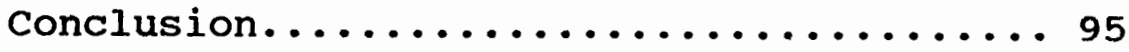

V LIBERAL AND CHRISTIAN EDUCATION:

CLARK'S CONVICTION..................... 99

Departure for Sapporo and the discussion

of Christianity aboard the Gembu Maru..... 101

The organization and curriculum of the

Sapporo Agricultural College........... 103

Clark in the field and classroom........ 111

The Kaishikisha, or

"Enlightenment Society"............. 117

The Bible and the classroom.......... 118

"The Covenant of Believers in Jesus"

and the Dokuritsu Kyokai, or "Sapporo

Independent Christian Church"......... 126

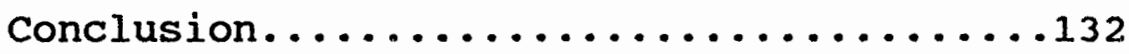


VI CLARK'S LEGACY AND CONTRIBUTION TO THE

MEIJI RESTORATION...................... 135

Clark's departure from the Sapporo

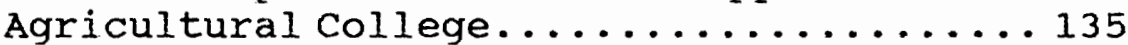

Inspection of the experimental farm at

Nanae and Izari, and the road between

Sapporo and Muroran................ 142

The survival of the Sapporo Agricultural

College: testimony to Clark's legacy...... 149



EPILOGUE...............................161

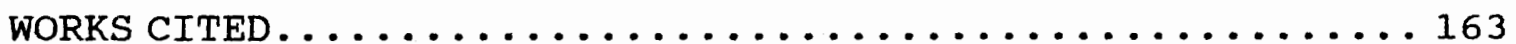

APPENDICES

A CLARK'S DESCRIPTIONS OF HOKKAIDO........... 170

B CLARK'S SERVICE RECORD IN THE CIVIL WAR....... 189

C CLARK'S DESCRIPTION OF THE EMPEROR OF JAPAN.... 194

D COURSE LIST AT THE SAPPORO AGRICULTURAL



E CHARTER OF THE KAISHIKISHA............. 200

F CHARTER OF THE COVENANT OF BELIEVERS IN JESUS ................................ 203

G LETTER FROM THE LEGATION OF JAPAN PETITIONING CLARK TO LECTURE AGAINST THE UNEQUAL

TREATIES...........................206 


\section{LIST OF FIGURES}

\section{FIGURES}

PAGE

1. A geological survey map of Hokkaido drawn by Benjamin Smith Lyman for the Kaitakushi on

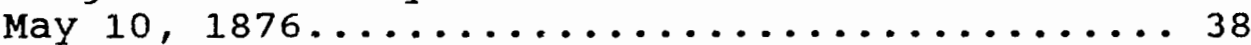

2. The statue of William Smith Clark at Hitsuji ga okatenbodai, in Sapporo, Hokkaido........... 39

3. The original building of the Sapporo Agricultural College, Sapporo, Hokkaido.......62 62

4. The first class at the Sapporo Agricultural college with Professors clark, wheeler, and Penhallow..........................663

5. A student's notebook from the Sapporo Agricultural College with corrections made by clark.......................... 97

6. The barn constructed under the supervision of Clark at the Sapporo Agricultural College, now recognized as a National Treasure by the Japanese government. . . . . . . . . . . . . . 98

7. Nitobe Inazo's (Christian name: Paul ota) notebook while studying at the sapporo Agricultural college.................. 133

8. Uchimura Kanzo's Bible while studying at the Sapporo Agricultural College, and member of the Sapporo Independent Christian Church...... 134

9. The parting picture taken at the honjin, the building where clark stayed while in Japan. . . . . . . . . . . . . . . . . . . . . 159

10. A painting at the old statehouse in Sapporo, Hokkaido, depicting clark speaking the words:

"Boys Be Ambitious," during his departure...... 160 


\section{CHAPTER I}

\section{INTRODUCTION}

Hitsuji ga Okatenbodai on Hokkaido, the northernmost island of Japan, is a park spread out on rolling green and purple hills, scattered with grazing sheep, and is the present location of a large, bronze statue of William Smith clark (1826-1886). One of his arms rests at his side, and the other is pointed toward Massachusetts, his home state. His bearded face proudly overlooks Sapporo, the largest city in northern Japan, and the capital of Hokkaido. The inscription on the base of the statue reads: "Boys, Be Ambitious," the last, and most inspiring words that clark announced before departing Hokkaido. The statue enjoys a central location at the park and is the subject, along with the faces of grinning tourists, of thousands of photographs everyday.

The park has several New England style buildings with a red star, the emblem of Hokkaido, painted on the side, and there is a small, charming white New England church overlooking the pastures. The church is used for Western style weddings, not for religious services. The gift shop has everything from bottles of air freshener shaped in the figure of clark, to chocolates, hair combs, fans, and posters, all in some way paying tribute to the late Massachusetts educator. 
Probably the most interesting piece of Clark memorabilia is the "Boys, Be Ambitious" club where for a fee a card with the inscription "Boys, Be Ambitious," and a photograph, the most popular being the two faces of newlyweds, is bestowed upon the new member. Wandering around the park is a Japanese man with a fake beard wearing a nineteenth century Western suit. Looking somewhat like Clark, he answers questions about clark and the impact he had on Hokkaido.

This is not the only place in Hokkaido, however, where one is impressed by the tribute -- whether in the. form of plastic figurines or scholarly essays on Christianity in Japan -- paid Clark. On the Hokkaido Expressway, just outside Sapporo, there is a sign with a picture of Clark saying "Boys, Be Ambitious," and the hottest-selling phone card features the Clark statue. There is a monument to clark at Shimamatsu, just south of Sapporo, and his bust is on the campus of Hokkaido University. In Chitose, just east of Sapporo and once the location of a large American occupation base, there is a private school named "The Academy of Clark's Spirit," and at the department store only three blocks away, the bookstore packs all its merchandise in bags that read: "Boys, Be Ambitious."

clark is known by virtually everyone in Hokkaido and his words have become synonymous with success. It is striking that Clark, unlike other historically important figures, is cherished by the people of Hokkaido, and not forgotten as 
another name in a high school entrance examination textbook. While clark was in Hokkaido there were roughly sixty foreign advisors working for the Hokkaido government, and many stayed in Japan for as long as fifteen years to make significant contributions to the settlement of the island. Clark stayed in Sapporo for eight months but is popularly regarded as the most important figure in Hokkaido's early development.

This sentiment has to do with the spirit of clark and the nature of the development he promoted while in Hokkaido. During the high point of Hokkaido's development, about fortyfive Americans came to Sapporo to assist with the process. Advisors from the United States assisted with the construction of everything from farms, mills, roads and bridges, to fisheries, breweries, telegraphs, and trains. Foreign advisors helped Hokkaido on its way to a more organized settlement, but it was Clark, and the sense of mission that he brought to Sapporo, who supplied the spiritual ammunition for the task that lay ahead. As the founder of the sapporo Agricultural college, he instilled a sense of industry and liberal intellectualism that later produced some of Meiji's most celebrated academics, and made the college not only the nerve center for Hokkaido, but an outstanding example in the history of education in Japan.

The Americans who came to Hokkaido are all examples of international cooperation, but clark remains a singular example. He attained the unquestioned trust of both his 
students and the officials of the Hokkaido government and was able to instill his personal values as an educated, christian republican on the people of Hokkaido. His students accepted these values, and in many instances fought for them during the troubling years of Japanese history that followed.

At first glance it is tempting, if for no other reason than the poor quality of the clark trinkets that fill the gift shops of Hokkaido, to believe that clark has been, as have so many other places and people, perverted into a commercial jackpot by a few shrewd business people. Clark's experience in Japan, however, proves to be far more valuable than just the revenues gathered from plastic figurines, and his stay in Japan, for this reason, is worthy of detailed, scholarly attention.

This study concentrates on Clark's contribution to agriculture, higher education, and the development of liberal, Christian scholarship in Japan. Although Clark simply founded a small agricultural college in the heart of the Japanese frontier, he proved more than just an agricultural advisor. It is the purpose of this study to show that clark, through the establishment of the Sapporo Agricultural College, acted às a catalyst for liberal and Christian education in Japan, while making a noteworthy contribution to the practical agricultural development of Hokkaido. During the Meiji Restoration, education was a vehicle for restructuring society and clark, through his contributions to education in Hokkaido, 
proves an important figure in the history of modern Japan.

Assistance with the practical development of Hokkaido, the pioneering of liberal scholarship and christian proselytizing, and the exciting observations made during his stay, all make william Smith clark a fascinating example of the depth of American cooperation with Japan during this extraordinary period, and of the nature of general reforms pursued by Japan during the nineteenth century.

By the time the imperial Japanese government recognized the importance of Hokkaido, the United States, on the. American continent, had just finished the first stages of the move westward. Through legislation and executive action, a series of laws were passed by the United States government to assure the quick and organized settlement of the west. The Japanese were about to undertake a similar move in Hokkaido and looked to the United States as the obvious example of how to carry out such a process. One of the most striking features of American expansionism was the promotion of education among the new settlements. Although centered around the church, these institutions were often responsible for the organized settlement of land, and the promotion of effective, scientific agriculture. Many of these institutions were based on the New England model.

Japanese intellectuals studying in the United states had long admired the New England education system. Many Americans hired by the Japanese to assist in educational reform in Japan 
were from New England. Clark was a logical choice for the Japanese: he was from New England and the president of the Massachusetts Agricultural College, an institution dedicated to practical agricultural development and the moral education of its students. The Japanese officials responsible for the acquisition of Clark's services were internationally-minded men, and had the best intentions of creating a liberal, New England-style university in the heart of Hokkaido.

Hokkaido has been called an "experimental farm for new knowledge"1 by the postwar prefectural government. This phrase is accurate in many ways. During the development of Hokkaido, foreigners were hired from all over the world to assist in the organized settlement of the island. Most of these advisors came from the United states, but a substantial number came from China and Europe. The Japanese were interested in the swift creation of an infrastructure for Hokkaido and on the whole had good results with foreign employees. Although there are a few examples of trouble between foreign employees and the imperial government, these usually were a product of poor behavior, not problems in international exchange, and they were quickly dealt with.

Clark came to Sapporo to preside over the establishment of an agricultural college that would "prove to be the brains

2 Hokkaido Prefectural Government, Foreign Pioneers: A Short History of the Contribution of Foreigners to the Development of Hokkaido (Sapporo, Hokkaido: Sapporo Government Press, 1968), p. 151. 
of the colonization of Hokkaido." 2 originally, the college was based on the practical needs of the region, but clark brought to Japan more than just his knowledge of scientific agriculture. Clark brought liberal reforms that were eagerly embraced by the Japanese whose society was undergoing enormous changes following the Meiji Restoration. The sapporo Agricultural College quickly became more than a vocational school; it was also a liberal arts institution that claimed to develop moral values, as well as practical skills, in people. It produced leading scientists and scholars who shaped, or attempted to shape, much of their age. In this sense clark not only left physical evidence of his influence, but an intellectual legacy as well. The Japanese of Hokkaido regard these intellectual influences as important, and believe that the pioneer spirit of Hokkaido, mixed with the international cooperation the island represents, is embodied by Clark and his moral character.

Beyond being a technical advisor and an academic, clark also was an observer, shot into the heart of Meiji Japan, collecting information about everything he encountered. Although Clark did not go to Japan for the purpose of collecting information, as a scholar he was observant and took notes of what he did and saw, even of what seemed unimportant at the time. As Clark's biographer John Maki states, Clark

2 Hokkaido Prefectural Government, Foreign Pioneers, p. 
displayed "the capacity for careful and detailed observation and the ability to set down such observation in clear and economical prose." ${ }^{3}$

Like a probe, clark was only able to detail facts that he came into contact with and so the historian, understanding the larger picture of what the Meiji Reformation meant for Japan, and what international cooperation meant for Hokkaido, is able to place the experiences of clark in a larger and more revealing context. By studying clark, the historian is left with something similar to a core sample taken from the earth by a geologist. Although the sample is cylindrical and limited, it testifies to the complexities of the soil and sheds light on the strata where answers to the most profound geological -- or in this metaphor, sociopolitical -- questions lie.

It is for these reasons that clark deserves a closer look by those who seek to understand the international dimensions of the transformation of modern Japan. He was brought to Japan by a great wave of historical momentum that was powered by many different components. Clark was a technical advisor, pioneer of international exchange, agent of moral reform, product of the Meiji leaders' obsession to modernize Japan, and observer of nineteenth century Japan. His experiences

3 John M. Maki, William Smith Clark: A Yankee in Hokkaido (Amherst, Massachusetts: Unpublished, available at Hokkaido University, Sapporo, Hokkaido or University of Massachusetts, Amherst, Massachusetts, 1953) Chapter VIII p. 10 . 
provide a wealth of valuable information about the transformation of Japan during this period.

The following chapter looks at the history of Hokkaido's settlement and the larger historical forces that were present in Japan and created the need and capacity for the Meiji leadership to introduce western learning to Japan. The third chapter deals with the process that brought clark to Hokkaido and the contract he signed with the Japanese government. The fourth and fifth chapters look at Clark's success as founder of the Sapporo Agricultural College and a liberal, Christian educator, respectively. The sixth chapter discusses clark's contribution to Hokkaido's settlement and to the Meiji period. 
HOKKAIDO, THE KAITAKUSHI, AND KURODA KIYOTAKA

Hokkaido's colonization in the nineteenth century was fueled by three goals: to secure the island in the face of Russian encroachment, to develop the abundant resources of Hokkaido in order to fuel the expanding industrial machine of modern Japan, and to provide room for the natural expansion of a growing population. The first steps in establishing an official Japanese presence on Hokkaido were to create an agricultural base in order to make the island self-sufficient, and to build an industrial infrastructure, such as coal mines and railway, from this foundation.

The subsequent history of Hokkaido's development reveals a push towards the mass colonization of the island, that is, to bring as many people as possible to Hokkaido, and the establishment of a strong agricultural base. The Japanese correctly assumed that by employing foreign advisors from the United states, and stressing education, they could more rapidly achieve these ends, and secure what was referred to as the "back door of Japan."

- Before the ascendance of Abe Masahiro to the forefront of Meiji policy, Tokugawa Nariaki had labeled Ezo the "back door to Japan." 
THE DEVELOPMENT OF HOKKAIDO UNDER THE MEIJI GOVERNMENT

Ezo, or "land of the barbarians," which includes Hokkaido, Sakhalin, and the Kurile Islands occupied by Japanese settlers, was never considered the center of Japanese civilization, and was culturally neglected until the middle of the nineteenth century. A native Ainu culture existed, and is fascinating in itself, but the Japanese, the masters of the archipelago, did not take an interest in Hokkaido until the nineteenth century. ${ }^{5}$ The Japanese under the leadership of the Tokugawa Shogunate, with the exception of some renegades and brave fisherman, were slow to populate the northern territory. The earliest contact made with Hokkaido by Europeans was in the seventeenth century, but it was later, in the eighteenth century, that the Russian Empire took the strongest interest in the northern region.

Russian military and settlement activity on sakhalin spurred Shogunate interest in Ezo. Japanese contact with the Russian Empire probably dated back to 1611 when a Japanese Augustinian monk was martyred in Moscow. ${ }^{6}$ Although in 1639 the Shogunate sealed Japan off from outside contact, the seclusionist empire involuntarily kept contact with Russia. In 1702 a Japanese sailor from Osaka was cast away after his

5 Hokkaido Prefectural Government, Foreign Pioneers, p. 138.

6 David Forsyth Anthony, The Administration of Hokkaido Under Kuroda Kiyotaka, 1870-1882 (New Haven, Connecticut: Ph.D. diss., Yale University, 1951), p. 3 . 
ship wrecked off the coast of Kamchatka. He was captured by Russian officials and brought to st. Petersburg, where he remained. Under his tutelage the study of Japanese language and culture was started in st. Petersburg.?

By 1770 Russian settlements expanded to the Kurile and Urup Islands. The shogunate was slow to act but some officials did see the potential danger of Russian encroachment. In 1781 and 1783, Kudo Heisuke, assisted by two other scholars, published a two-volume work entitled Aka Yezo Fusetsu Ko, or "A Discussion of Rumors Concerning the Russians." In the work, Kudo's final recommendation, after detailing the chronology of Russian advancement in Ezo, was the development of coal mines in Hokkaido and the organization of settlements that could carry on legal trade with Russia in order to increase the wealth of the shogunate. ${ }^{8}$

Tanuma okitsugu, a chief minister (1767-1786) and advocate of mercantilism in the Tokugawa economy, became interested in Kudo's work. Tanuma was impressed by Kudo's suggestion that a failure to colonize and develop Hokkaido would result in the loss of the island to Russian expansion.? Tanuma made elaborate plans to implement Kudo's suggestions,

7 Ibid.

s Ibid, p. 5 .

- Nakane Chie and Oishi Shinzaburo, Tokugawa Japan: The Social and Economic Antecedents of Modern Japan, trans. Conrad Totman, (Tokyo, Japan: University of Tokyo Press, 1990), p. 34 . 
but was assassinated before he could accomplish anything in Ezo. In 1792, another work, entitled Sankoku Tsuran, was completed by Hayashi Shishi detailing Russian encroachment in Ezo. The book warned that steps must be taken to deal with the ever-present Russian menace.

Matsudaira Sadanobu (1758-1829), a Shogunate minister who undertook dramatic economic reforms, including attempts to check expenditures and profit-making, became interested in Ezo for economic reasons.10 Matsudaira made plans to halt Russian advancement in Ezo, as the land in the north was important to the implementation of his reforms. Before he resigned from government in 1793, he had several ships built, using the Dutch model, that were fit to defend the shores of Hokkaido. He also suggested that authority to defend Ezo be put in the hands of the Matsumae clan. ${ }^{11}$ Russian interest in Ezo never ceased but subsided when Europe was occupied with the Napoleonic Wars. Russia was forced to focus its attention on the invasion forces from Europe. The Shogunate was also occupied in the middle of the nineteenth century with events that ultimately lead to its removal from power.

In April, 1868, Emperor Meiji (1852-1912), with the advice of a core of powerful Satsuma and Choshu advisors which formed the Meiji leadership, issued the Gokajo no Gosemon, or

10 Conrad Totman, Politics in the Tokugawa Bakufu, 16001843 (Cambridge, Massachusetts: Harvard University Press, $1967)$, p. 86 .

11 Ibid., p. 86-88 passim. 
"Five Charter Oath." The fifth part of the Oath specified that "knowledge was to be sought throughout the world to strengthen the foundations of the Imperial rule."12 In the spirit of leading Japanese westernizers like Fukuzawa Yukichi (1835-1901), foreigners were sought out and invited to Japan in an effort to strengthen the imperial nation. ${ }^{13}$ The Imperial oath is an important factor in the eventual employment of Clark as foreign advisor to Hokkaido because education, as specified by the edict, was instrumental in the restructuring of Japanese society during the Meiji Restoration. ${ }^{14}$

Clark's appointment to head the Sapporo Agricultural College was the product of a convergence of powerful historical forces in Japan with the life and experiences of an American educator from New England. As Japanese in the nineteenth century witnessed results from the West's intrusion into China through the Opium Wars, Meiji leaders formulated the policy of fukoku kyohei, or "enrich country, strengthen the army." This thinking included the shrewd strategy of importing the ideas and technology that made the western nations powerful and enabled Japan to withstand the threat

12 Janet E. Hunter, Concise Dictionary of Modern Japanese History (Berkeley and Los Angeles, California: University of California Press, 1984), p. 23.

13 Ardath $W$. Burks, The Modernizers: Overseas Students, Foreign Employees, and Mei ji Japan (Boulder, Colorado, London, England: Westview Press, 1985,) p. 166.

$14 \quad$ Ibid., p. 257-258. 
from abroad. The Meiji government made the decision to send students abroad and also to invite advisors to oversee the creation of new institutions in Japan.

The Meiji leaders chose models throughout the world in an attempt to strengthen Japan against outside aggression. The United states was the chief model for agricultural education at the time. It was logical that clark was chosen to lead the Sapporo Agricultural College. As Nitobe Inazo (1862-1933), a student of Clark, suggested: "the primary education of Japan of that period was, in substance, identical in every aspect with that of the united States."15

Hokkaido became a focus of education and international cooperation between the United States and Japan. ${ }^{16}$ Nearly 31,000 square miles in area, roughly the size of Maine, Hokkaido became a concern of the imperial government as the Russian threat grew, and Japan looked for economic and agricultural resources to feed its blossoming industrial strength. Thus, under Meiji leadership, Hokkaido came to command government attention as it never had in the past.

15 Nitobe Inazo and others, Western Influences in Modern Japan: A Series of Papers on Cultural Relations (Chicago, Illinois: The University of Chicago Press, 1931,) p. 36.

16 Burks, The Modernizers, p. 370-371. 
EARLY ATTEMPTS BY THE MEIJI LEADERSHIP TO

SETTLE EZO AND THE RISE OF KURODA KIYOTAKA

In March, 1868, the administration of Ezo was empowered to a sotoku, or "Governor-General," who headed the Hakodate saibansho, or "Hakodate court of Law." This term is misleading, however, because the saibansho served as much more than just a court, but as an administrative body as well. The saibansho was put in charge of observing Russian encroachment from the north. The first Governor-General of the saibansho was Shimizudani Kinnaru, but because of rebellion in Hakodate, financial, military, and technical assistance was unavailable, and his administration proved impotent.

on June 4, 1869, after the defeat of the rebels in Hokkaido, which will be discussed later in more detail, Nabeshima Naomasa was appointed Ezo Kaitaku Tokumu, or "Special officer for Ezo Development." Nabeshima's health failed him, however, and the position was given to Higashikuze Michiyomi. He arrived in Hokkaido with his staff on September 25, 1869, and under his administration Hokkaido officially received its name, and Higashikuze's new title became Hokkaido Kaitaku Chokan, or "Governor of Hokkaido's Development."

Russian advancement continued and by 1870 successfully prevented Japanese fisherman from building a wharf at Kushunkotan on Sakhalin. The Meiji leadership was in a position do nothing to ensure Japanese rights in the region, as the Ministry of Military Affairs, then headed by Kuroda 
Kiyotaka (1840-1900), was unwilling to commit imperial troops in Ezo. On May 9, 1870, the imperial government, moved to act in Ezo, appointed Kuroda as Director of Sakhalin Affairs. Kuroda quickly became the main figure in the development of Hokkaido and the normalization of relationships with the Russian Empire. Kuroda was also the major architect of the education policy in Hokkaido, and the leading force that brought Clark to Japan.

Kuroda Kiyotaka was born in 1840 in the domain of Satsuma on the southern island of Kyushu. He was a member of a low ranking samurai family. His parents died when he was young and he was forced to carve out a life of his own in the newly emerging Japanese society.

While a young man Kuroda became a member of the seichu gumi, or "Loyalty Society," and fostered a keen interest in patriotism. The seichu gumi was one of many patriotic societies that discussed a variety of topics including the restoration of imperial authority. These societies played a important role in formulating radical opinions among many samurai. In 1862, Kuroda, as a member of a military escort for the daimyo, or "feudal lord," of Satsuma, Shimazu Nariakira $(1808-1858)^{17}$, made his first trip to Kyoto. Kyoto

17 Shimazu Nariakira became daimyo of Satsuma in 1851. He studied Dutch learning and was considered a leader of Shogunate reform. He believed that in the face of the foreign threat Japan should build up its economy and military and deal with the west in this manner. He was retired after the dispute surrounding the shogunal succession in 1858 found him supporting the wrong man, Tokugawa Keiki. (Hunter, concise 
was the center of restoration and intrigue and Shimazu had come to petition reforms from the shogunate. Kuroda returned to Kagoshima, the capital of Satsuma, in 1863 , just in time to see the city bombed by British cannon following the Namamugi Incident. ${ }^{18}$

Kuroda left for Tokyo with Oyama Iwao (1842-1916)19 shortly following the bombardment. ${ }^{20}$ By 1864 the shogunate was in trouble. The shogun made a trip to Kyoto and banned the imperial capital from further communicating with Satsuma. The shogunate reckoned that by banning Satsuma leadership from

Dictionary of Modern Japanese History, p. 199.)

${ }_{18}$ In September, 1862, a British merchant named Charles Richardson was killed in Namamugi. He was slain by samurai after being accused of not giving proper respect to Shimazu Hisamitsu. Richardson's party had failed to give way to shimazu's procession, and he was cut down. The British government logged a strong protest demanding reparations from both the shogunate and the Satsuma clan. The shogunate paid, but the Satsuma leaders declined to cooperate. In August, 1863, a British squadron entered Kagoshima Bay and leveled much of the city, but departed considerably damaged by the strong Satsuma defense. The Satsuma leadership later borrowed the money from the shogunate to pay the reparations, and developed good relationships with the British Empire. (Hunter, Concise Dictionary of Modern Japanese History, p. 140.)

19 Oyama Iwao was a cousin of Saigo Takamori. He studied in France from 1871-1874 and after returning to Japan became one of the leading architects, along with Yamagata Aritomo, of Japan's modern military structure. He held many powerful administrative positions and was Commander and chief of the Second Army during the Sino-Japanese War and Supreme Commander of the Manchurian Army during the Russo-Japanese War. During the war with Russia, Oyama fought with great distinction and later became famous for his valor. (Hunter, concise Dictionary of Modern Japanese History, p. 162.)

20 Anthony, The Administration of Hokkaido, p. 12 . 
Kyoto it could head off organized opposition to Tokugawa authority. Shimazu recognized shogunate entrenchment and in 1865 delegated Okubo Toshimichi $(1830-1878)^{21}$ to formulate new policy towards the Tokugawa government.

Under the authority of Okubo, Kuroda focused his energies on the political concerns of the Satsuma clan. Okubo is often credited with the formulation of critical agreements between Choshu and Satsuma, but it was actually Kuroda, acting under Okubo's authority, who convinced Kido Koin (1833-1877)22 of the Choshu clan to attend a meeting with okubo and Saigo Takamori (1828-1877) ${ }^{23}$. The assignment was difficult. At

21 Okubo Toshimichi abandoned his support for the bakufu in 1865 and devoted much of his time to the formulation of ties between satsuma and choshu. He is regarded as one of the most powerful men in the Meiji oligarchy and shaped many of the radical policies that were instigated by the Restoration. Okubo went on the Iwakura Mission in 1871 and upon his return promoted the rapid development of Japan's industry as opposed to an invasion of Korea eagerly sought by the powerful Saigo Takamori. Okubo was made Home Minister in 1874 and was regarded as the focus of the Meiji government. He was assassinated by a discontent samurai on May 14, 1878 . (Hunter, Concise Dictionary of Modern Japanese History, p. 157.)

22 Kido Koin was a member of the Choshu clan. He played a major role in the anti-foreigner movements and the antibakufu movements. He was a major figure in the sonno joi, or "Revere the Emperor, expel the barbarian," frenzy after the arrival of Perry. He contributed to the drafting of the Charter oath and was a major supporter of the abolishment of clans and the promotion of the centralized state. He is often regarded as a progressive advocate of internal reforms and an idealist. He became ill in 1877 and was thereafter unable to participate in government. (Hunter, Concise Dictionary of Modern Japanese History, p. 92.)

23 After being banished twice for supporting the wrong candidates during Shogunal successions, Saigo Takamori became the Satsuma clan's agent in Kyoto and became involved with 
first Choshu leaders were suspicious of Kuroda, but later agreed to the meeting which ended in success on January 21 , 1866, and sealed the fate of the shogunate. ${ }^{24}$

Tokugawa Keiki (1837-1913) realized the desperate condition of the shogunate and signaled that he would relinquish power. After being baited by the Satsuma-Choshu coalition, however, he launched a final campaign against Kyoto in February, 1868, which ended with the utter defeat of the Shogun's forces. Kuroda played an active roll in the fighting, laying siege to shonai Castle and, through diplomatic maneuvering, persuading the garrison to abandon the castle and swear allegiance to the imperial government. His ingenuity was duly noted by the Meiji leadership.

On April 21, 1868, when the hostilities on Honshu were nearly concluded, Admiral Enomoto Takeaki (1836-1908) fled north to Hokkaido with the seven Dutch-made ships commissioned by Matsudaira. In October, 1868, Enomoto sent a letter to the

national politics. In 1866, after playing an important role in the conclusion of the Satsuma-Choshu alliance, he became a major force in the movement to destroy the shogunate. He was a force behind the 1868 coup d'etat and led troops in the Boshin conflict. He was later made Commander and Chief of the Imperial guard. During the Iwakura Mission in 1871, Saigo strongly urged an invasion of Korea but was overruled. He later quit the Imperial government and returned to satsuma where he founded a private school that specialized in military and Buddhist training. In 1877 he started the Satsuma Rebellion and upon the defeat of the rebellion by Imperial forces he committed suicide. He is regarded as one of the three most powerful figures behind the Meiji Restoration. (Hunter, Concise Dictionary of Modern Japanese History, $p$. 184.)

24 Anthony, The Administration of Hokkaido, p. 14. 
Emperor proclaiming his occupation of Hokkaido. He detailed the danger of Russian advances and justified his occupation on patriotic grounds -- loyalty to the Emperor. On October 19, 1868, Enomoto landed with his followers near Hakodate, subdued local resistance, informed foreign embassies in the city of his intentions, and secured the area.

Enomoto proclaimed an independent republic on Hokkaido and gave all samurai the right to vote. He made Goryokaku the capital of the republic and nominated himself president. Enomoto's republic, however, as with other attempts to settle Hokkaido, was plagued with logistical problems from the outset and on April 9, 1869, when Kuroda landed at Otobe village with imperial soldiers, Enomoto was unable to offer effective resistance. As Kuroda's troops approached Hakodate the fighting intensified and on the night of May 10, Kuroda led a small force of men up Mount Hakodate and seized the high ground over the city. On May 17, 1869, Enomoto officially surrendered. ${ }^{25}$ Kuroda later worked to have Enomoto released from prison and he became a valuable advisor.

Okubo, meanwhile, had developed an interest in Ezo. He

25 After his defeat Enomoto gave a three volume work on maritime international law by Theodore ortolan to Kuroda. He believed the work would be of use to the Restoration government. Kuroda was impressed by Enomoto and petitioned the Meiji government to release him from prison after his surrender. Fukuzawa Yukichi, a distant relative of Enomoto's, also petitioned the government for Enomoto's release. He was later set free because of the pressure applied by Kuroda despite powerful opposition by kido for his execution. Enomoto later became a valuable advisor to Kuroda in Hokkaido. 
formed a commission, which offered three recommendations: one, that the colonization of Hokkaido be encouraged; two, that the administration of Hokkaido be distributed between existing han; and three, that an agreement be concluded with Russia for the mixed inhabitation of Sakhalin Island. ${ }^{26}$ Okubo had come to regard Ezo as the greatest threat to Japanese security and on July 21, 1870, after personally hosting a party for Kuroda, sent him to resolve the Ezo issue.

KURODA AND THE CENTRALIZATION OF THE KAITAKUSHI

After his appointment as Director of Sakhalin affairs, Kuroda, following a detailed investigation of the problem in Ezo, concluded that a military conflict between Russia and the Japanese Empire was inevitable. He suggested that if Japan were to effectively deal with Russian encroachment, in the spirit of the Charter Oath, students must be sent to Europe and the United states to study science and strengthen good will between Japan and other nations. ${ }^{27}$ Kuroda also recommended that the existing authority in Hokkaido, which had been divided into spheres of han authority since okubo's initial interest in the area, be centralized under the

26 Anthony, The Administration of Hokkaido, p. 22 .

27 John A. Harrison, Japan's Northern Frontier: A Preliminary study in Colonization and Expansion with Special Reference to the Relations of Japan and Russia (Gainesville, Florida: University of Florida Press, 1953), p. 109-121 passim. 
Kaitakushi" or "Hokkaido Colonization Board." Kuroda began by traveling through Hokkaido and Sakhalin conferring with Japanese community leaders and Russian authorities.

While in Sakhalin, Kuroda received a pledge from Russia that it would respect Japanese territorial rights in the area. The Russian commitment is regarded as a prelude to regional boundary decisions that Kuroda would conclude by treaty in 1875. Kuroda thought it unwise for the imperial government to concentrate on settlements in Sakhalin. He suggested instead, in a recommendation that later became Japanese policy, that the government concentrate its efforts in Hokkaido specifically, making sure that the "back door to Japan" did not fall into Russian hands. Kuroda insisted that all efforts be made by the Raitakushi to insure that a strong, organized, and well-developed presence was established by the Japanese in Hokkaido.

Kuroda wrote his recommendation in a memorandum which he sent to okubo. Kuroda knew that okubo would be sympathetic to the Ezo issue. In the memorandum, Kuroda set out four recommendations: one, that Hokkaido be settled along the Ishikari plain, a central and fertile location; two, that a budget of $1,500,000$ ryo be granted to the Hokkaido project; three, that all authority in Hokkaido be centralized under the Kaitakushi; and four, that foreigners should be invited from

28 Kaitakushi is translated as kai, or to open, and takushi, is to delegate authority. Thus the translation "Hokkaido Colonization Board." 
abroad to supervise and offer technical assistance to the development of the island. The last suggestion was, of course, relevant to the career of clark, and the enormous international exchange between the United states and Japan that took place on Hokkaido.

Minister Sanjo Sanetomi $(1837-1891)^{29}$ replied to Kuroda on November 17, 1870, expressing support for the recommendations, and by January 1, 1871, Kuroda was on his way to the United States accompanied by over twenty students bound for European and American universities. Once in the United States Kuroda met with the Japanese Charge $d^{\prime}$ affaires Mori Arinori (1847-1889) $)^{30}$ who arranged a meeting between Kuroda and President Grant. Kuroda explained to Grant the needs of the Japanese concerning the settlement of Hokkaido and Grant recommended that Kuroda speak to Commissioner of Agriculture

29 Sanjo Sanetomi was an anti-Shogunate leader and major player in Meiji affairs. He held the highest offices in the Meiji government and was Dajo Daijin, the highest official under the Dajokan system. In 1889 he temporarily acted as Prime Minister and retained the title of Privy Seal until his death. (Hunter, Concise Dictionary of Modern Japanese History, p. 189.)

30 Mori Arinori was also from a Satsuma samurai family. He studied in England and the United states and joined the Meiji government serving as Envoy to the United States, to China, and to England. In 1885 he was appointed Minister of Education by Ito Hirobumi. He became the most powerful figure in Japan's prewar education system. Mori strongly believed, using the German model, that education was for the purpose of the state. Mori, however, should not be criticized offhandedly, as his initial reforms in education were often liberal in nature. He was assassinated in 1889 by conservative nationalists suspecting him of harboring proWestern sentiments. (Ivan Parker Hal1, Mori Arinori (Cambridge, Massachusetts: Harvard University Press, 1973).) 
General Horace Capron. ${ }^{31}$

Kuroda and Mori submitted a memorandum to Capron detailing the needs of the Kaitakushi. Capron, fortunately for Kuroda, was willing to come to Japan himself and assist. On May 7, 1871, Mori officially confirmed Capron's appointment and the General assembled his staff. ${ }^{32}$ By August 28, 1871, Kuroda and Capron had arrived in Yokohama. Capron played an integral role in the development of Hokkaido, and is considered one of the most important and useful foreign advisors the Kaitakushi employed. Capron believed that the first step in the organized colonization of Hokkaido was the establishment of an agricultural base, and subsequently, an agricultural college.

While Kuroda was in Washington D.C., the Meiji leadership had taken steps to reorganize Hokkaido along the lines specified by Kuroda in his earlier memorandum. In April, 1871, Higashikuze traveled to sapporo and set up the new Kaitakushi headquarters in a group of military barracks. Sapporo, the new capital of Hokkaido, was located on the Ishikari plain.

On August 20, 1871, the Kaitakushi was given a budget of one million ryo for a period of ten years. Thus, by August 20, 1871, all money and land for the Ezo project were placed

31 Harrison, Japan's Northern Frontier, p. 109.

32 Capron employed Dr. Thomas Antisell, Stuart Eldridge, and A.J. Warfield to assist him while in Hokkaido. 
in the centralized control of the Kaitakushi. The centralization of authority in the Kaitakushi, and the abolition of han control, was a forerunner to events on August 29, 1871, when the Meiji leadership ordered the abolishment of all feudal clans and the creation of a centralized government in Tokyo. ${ }^{33}$

In July, 1869, the Kaitakushi organized a large scale settlement of Hokkaido that proved ineffective. In November, 1869, the imperial government proclaimed that soldiers who had fought with Enomoto around Hakodate could settle in Hokkaido. The early colonists in Hokkaido were samurai who found themselves without direction in the new Japanese society. Although the settlement policy of the Kaitakushi changed on several occasions, it always favored the rapid, organized occupation of the island.

On January 2, 1872, Capron issued his first report to the Kaitakushi, urging dramatic reforms. Capron was critical of the subsidies being paid by the Kaitakushi, and recommended that the policy be changed. Kuroda listened to Capron's suggestions and by late 1872 had experimented with several different types of colonization. Two points are clear about the Kaitakushi's settlement of Hokkaido under the direction of Kuroda and Capron: one, that all settlements were planned along agricultural lines because Capron believed that agricultural development was the most fundamental step in 
making the island self-sufficient; and two, that the settlements of Hokkaido were extensive rather than exclusive, to make the process as rapid as possible. ${ }^{34}$

In December, 1873, Kuroda recommended to Tokyo that a militia be established in Hokkaido for agricultural and defensive purposes. Kuroda believed that the militia could play an integral part in the settlement of the Ishikari plain, and the preservation of Hokkaido. The government was quick to applaud the plan, since disaffected samurai could be organized into the militia, thus focusing their energy away from the Meiji leadership. Kuroda received support from Tokyo and in June, 1874, was made lieutenant-general in the imperial army and head of the Hokkaido militia. This appointment was followed by two others: on August 14,1874 , Kuroda was made Kaitaku Chokun, or "Governor-General" of Hokkaido; and he later was given imperial ranking by the emperor of Japan.

In september, 1871, pursuant to the suggestion of Capron, land from private estates was turned over to the Kaitakushi for the purpose of creating experimental farms. These initial farms were called kanen, or "governmental gardens," but by March, 1875, were referred to as noji shieken jo, or "agricultural experimental stations." Under the supervision

34 Kuroda was fairly successful with the rapid colonization of Hokkaido as some statistics indicate. Before Kuroda's policies went into effect, the total area under cultivation in Hokkaido was roughly 2000 acres. By 1881 this figure increased to 49,000 acres. (Anthony, The Administration of Hokkaido, p. 82) 
of Capron, many kinds of stock, crops, and machinery were imported from the United States for use on the experimental farms. ${ }^{35}$ The farms were just one step in a deliberate policy to step up the settlement of Hokkaido, establish selfsufficiency, and defend the land from Russian advances.

Under Kuroda and his American staff the Kaitakushi also devoted energy to developing a strong infrastructure and communications network in Hokkaido. On April 1, 1871, Kuroda sent a memorandum to Capron stating that because Japanese civilization tended to thrive along roads and communication lines, he believed the construction of such works would make Hokkaido more attractive for settlement. ${ }^{36}$ The first project was a road between Hakodate and Sapporo. The road was contracted by Hirano Taro and construction was supervised by one of Capron's staff, Major Warfield. ${ }^{37}$ Although the road took longer than expected, and was soon partly washed away or

\footnotetext{
35 Anthony, The Administration of Hokkaido, p. 85.

36 Ibid., p. 115 .
}

37 During the construction of the road, Warfield became the first of Capron's staff to be discharged from the service of the Kaitakushi. He often flew into rages and in one incident, while drunk, shot three valuable Ainu hunting dogs. After returning to Sapporo, Warfield started drinking everyday and one morning, before breakfast, was visited by N.W. Holt who found him raging drunk. He argued with one of his students and an interpreter and drew his knife and cut off the interpreter's finger. He then tried to flee on horseback but was intercepted by Kaitakushi officials. Kuroda, upon hearing about the incident, discharged Warfield and refused to pay for his departure. Capron and Holt petitioned to have him pardoned, but Kuroda would not budge. Kuroda later seemed most offended that Warfield had broken all the expensive ceramics in his room. 
riddled with holes, it was eventually completed. Other roads were constructed and these became the crude communications network of Hokkaido. In 1874, a telegraph wire, which stretched across Hokkaido, under sea, and then to Tokyo, was completed by the Kaitakushi. It effectively linked the island with the capital of the Japanese empire. ${ }^{38}$

on May 7, 1875, negotiations conducted under the close supervision of Kuroda were concluded with a treaty between Japan and Russia. The treaty effectively established boarders between the two expanding empires and eased, at least for the time being, mounting tensions of a coming military conflict. It was a major diplomatic breakthrough for Kuroda, and gave him time and space to concentrate on further improvements for Hokkaido. In 1878, Joseph Crawford arrived from California to survey the region for railway lines. Crawford completed the survey in 1879 and returned to the United states to purchase the necessary material for constructing the railroad. With Crawford overseeing the project, the railway was completed in 1882 and made accessible valuable coal deposits that had been discovered earlier by the Massachusetts geologist Benjamin Lyman. ${ }^{39}$ Lyman surveyed much of Hokkaido and drew up the first scientific map of the island. Lyman was responsible for the discovery of coal deposits at both Horonai and Iwanai, passim.

Harrison, Japan's Northern Frontier, p. 109-121

39 Anthony, The Administration of Hokkaido, p. 128. 
which later developed into some of the richest coal mines in Japan.

Under Kuroda and his American staff the Kaitakushi also reorganized Hokkaido's fishing and logging industries. On August 10,1872 , the first sawmill was built in sapporo under American supervision, and in January, 1874, Capron suggested that Kuroda create a brewery in Sapporo. An American botanist, who had noted during his survey of Hokkaido a number of indigenous hops, had earlier suggested that sapporo would be ideal for the establishment of a brewery. Kuroda accepted the proposal and by 1876 the first products of the brewery were tasted. It was the first brewery in Japan and today is still the most famous, and is one of the lasting institutions of the Kaitakushi.

KURODA AND THE KATTAKUSHI'S POLICY ON EDUCATION

Kuroda and his American advisors recognized the necessity of introducing institutionalized education to Sapporo. Kuroda had recommended to leaders in Tokyo that students from Hokkaido be sent abroad for education, and considering the Russian menace at the time, Kuroda was probably thinking of both practical and military training. Kuroda suggested that, given the needs of Hokkaido, a school that specialized in scientific and practical agriculture would best suit sapporo. Capron told Kuroda on several occasions that agriculture, the basis of self-sufficiency, was the first step in the direction 
of any organized settlement. Kuroda, acting upon these suggestions, pushed for the creation of a school in Hokkaido that could train people in the skills necessary for a productive agricultural base.

When Capron first arrived in Hokkaido he had spent a great deal of time tutoring Japanese officials in scientific agriculture as it was practiced in the United states. If any of Capron's initial reforms were to be implemented, trained workers were needed for their effective operation, and education was the best means to train those needed for smooth reorganization. After the creation of the experimental farms, Capron used the plots to demonstrate modern agricultural techniques to Japanese who were working on the farms, and these efforts are regarded as the first steps to educate Kaitakushi employees in scientific agriculture. ${ }^{40}$ It was education born out of necessity.

While in the United States Kuroda had toured several universities and land grant institutions with Capron and was impressed by the contribution that the schools made to the development of agriculture in the United States. ${ }^{41}$ After returning to Japan, Kuroda and Higashikuze wrote a memorandum to Tokyo on September 14,1871 , recommending the creation of a school for sapporo based on the land grant model. In a

Ibid., p. 98 .

\footnotetext{
passim.

41 Harrison, Japan's Northern Frontier, p. 115-121
} 
second memorandum written October 5, 1871, Kuroda recommended that more students be sent abroad to acquire foreign knowledge and to return as resources for the development of Hokkaido. Kuroda suggested that women students be sent abroad to acquire the sophistication that Kuroda had noticed in American women during his travels to the United States. Kuroda believed that women would play a valuable role in the settlement of Hokkaido. ${ }^{42}$

Tokyo accepted Kuroda's suggestions and by November 18, 1871, preparations were being made to send five women to the United states. Their departure was widely publicized and the Empress presented the women with gifts on their departure. Their ages ranged from ten to seventeen and, although they never returned to Hokkaido as was originally planned, after their return to Japan they led distinguished lives. One of them, Tsuda Umeko $(1865-1929)^{43}$, founded and became the first President of the Tsuda English College for Women. ${ }^{44}$

On January 2, 1872, Capron wrote a memorandum to Kuroda indicating the necessity for an institution that specialized

42 Ibid., p. 109-115. passim.

43 Tsuda returned to Japan from the United States in 1882 and taught at the Peeresses' School, but in 1900 resigned and started the Girls English School, now Tsuda Women's University. Even after retiring in 1917, she remained active in the movement to educate women in Japan. (Hunter, concise Dictionary of Modern Japanese History, p. 235.)

44 Nitobe Inazo, The Imperial Agricultural College of Sapporo, Japan (Sapporo, Hokkaido: The Imperial Agricultural College, 1893), p. 2 . 
in scientific agriculture. Capron's memorandum, written from the experimental farm in Tokyo, was as follows:

It should be the endeavor of this government to establish by every possible effort, scientific, systematic, and practical agriculture. In no way can this be done more effectively or economically than by connecting with the gardens at this place (Tokyo) and also with the farms at Sapporo, institutions at which shall be taught all the important branches of agricultural science. These institutions should have well appointed laboratories, and should be supplied with professors of knowledged ability in their several specialties. A professor of Entomology would, for example, be of incalculable service to the farmers of this country where the insects annually destroy millions of dollars worth of property. ${ }^{45}$

On January 20, 1872, Kuroda wrote the Dajokan, or "Council of state," again stressing the need to establish an agricultural school in sapporo. The council accepted the proposal with some modifications. Kuroda earlier indicated that the school should be equivalent to elementary education in the present system, but the council suggested that the school should be the equivalent of the middle-school. The council also recommended that the school be set up in Tokyo, as facilities in sapporo were still too crude to accommodate the proposed institution. On March 10, 1872, with Ikonosuke Arai as principle, the Temporary school held entrance examinations, and on May 15, 1872, was officially opened. The school was called the Temporary School because it was agreed that as soon as Sapporo was adequately equipped to handle the 
new institution, it would be moved to the northern capital. ${ }^{46}$ The Temporary School proved to be inadequate, however, and was shut down. Unlike the program suggested by Capron, the school had no properly educated foreign instructors. Also, most of the students were older, unruly samurai, and discipline proved to be a major problem. On March 14, 1873, Kuroda, enraged by the lack of discipline at the school, ran into the school yard wielding a huge staff and shouted: "Everybody get out! People like you are worthless to me!"47 The students left and the school was closed.

In coordination with the establishment of the Temporary School in Tokyo, Kuroda had established a girl's school that was to educate women as potential wives for the graduates of the Temporary School. Kuroda worked closely with the Dutch Consul and acquired the services of two university-educated Dutch women to teach at the school. The school opened in September, 1872, but was closed when the second Temporary School moved to sapporo. Kuroda's work makes him one of the pioneers of women's education in Japan. Until 1875, when Dr. David Murray of Rutgers College became the chief advisor to the Ministry of Education, no official had recognized the need to educate women in Japan more than Kuroda. ${ }^{48}$

In 1873 Kuroda reorganized the Temporary School. He

46 Nitobe, The Imperial Agricultural College, p. 5-6.

47 Anthony, The Administration of Hokkaido, p. 102.

48 Ibid., p. 103. 
accepted only boys aged twelve to sixteen and integrated strict discipline into the school curriculum. He made the new students sign a bond that upon graduation they would work for the Kaitakushi until the termination of their training. The reorganized Temporary School proved more successful and on November 30,1874 , Director Zusho Hirotake wrote Kuroda that the students were coming along nicely. In the memorandum, Zusho reiterated the suggestions of Capron, and recommended that three professors be sought from abroad to teach agricultural science at the school. On February 23, 1875, Zusho sent Kuroda a detailed sketch of the Temporary School's needs using the Massachusetts Agricultural College as a model. Upon consultation with Capron, Zusho concluded that three professors were needed: one to teach veterinary surgery, physiology, and zoology; one to teach chemistry and agriculture; and the other to teach mechanical training, physics, and mathematics. Zusho estimated that the total cost to hire such qualified individuals might be around $\$ 30,000 .{ }^{49}$ In March, 1875, Kuroda wrote Prime Minister Sanjo in regard to the acquisition of foreign instructors. Kuroda, unlike Zusho, insisted that all instructors be hired from the United States. Kuroda believed that the United States not only offered the best model in land settlement, but that the New England educational system, with its emphasis on both the moral and practical aspects of learning, was the best example 
in the world and would serve the Kaitakushi well.50 Kuroda put Yoshida Kiyonari in charge of the search and specified that any instructor considered was to be an individual of "superior character," an example to the Japanese students in the classroom.51 That same month a committee composed of Zusho, Mori Genzo, Yuchi Sadamoto, Ikawa Kiyoshi and Hori Seitaro decided to move the Temporary School to Sapporo where it was named the sapporo School.

\section{CONCLUSION}

The colonization of Hokkaido was a rapid process that involved close cooperation between American and Japanese officials. It became apparent early on that a school that specialized in scientific agriculture was imperative for the organized and sustained improvement of life in Hokkaido. Under the direction of Kuroda and Capron, the early development of Hokkaido involved a series of policy decisions that lead to the establishment of an agricultural college on the island, and thus to the engagement of Clark. Also, Kuroda displayed an interest in liberal education, believing, as did many in the Meiji leadership, that strong values among students, that is, values dedicated to the advancement of the Japanese empire, were essential to the modernization process. To these leaders, the vehicle to instill practical and moral

5o Burks, The Modernizers, p. 214.

51 Anthony, The Administration of Hokkaido, p. 106. 
training in students was education, and thus the search for a person of superior moral character became the mission of the Kaitakushi. 


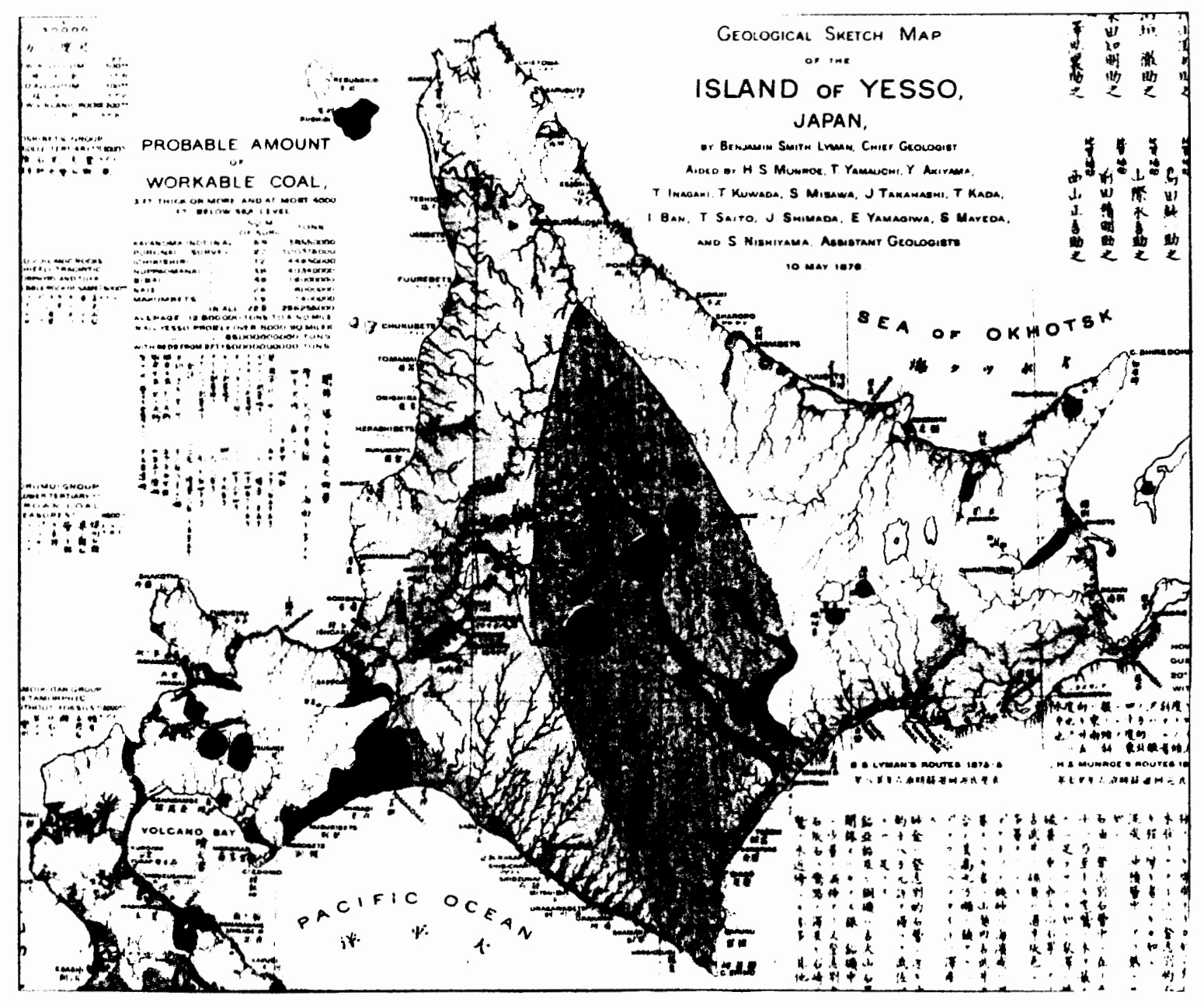

Figure 1. A geological survey map of Hokkaido drawn by Benjamin Smith Lyman for the Kaitakushi on May 10, 1876 . (Benjamin Smith Lyman collection, Archives and Manuscripts Department University Library, University of Massachusetts at Amherst.) 


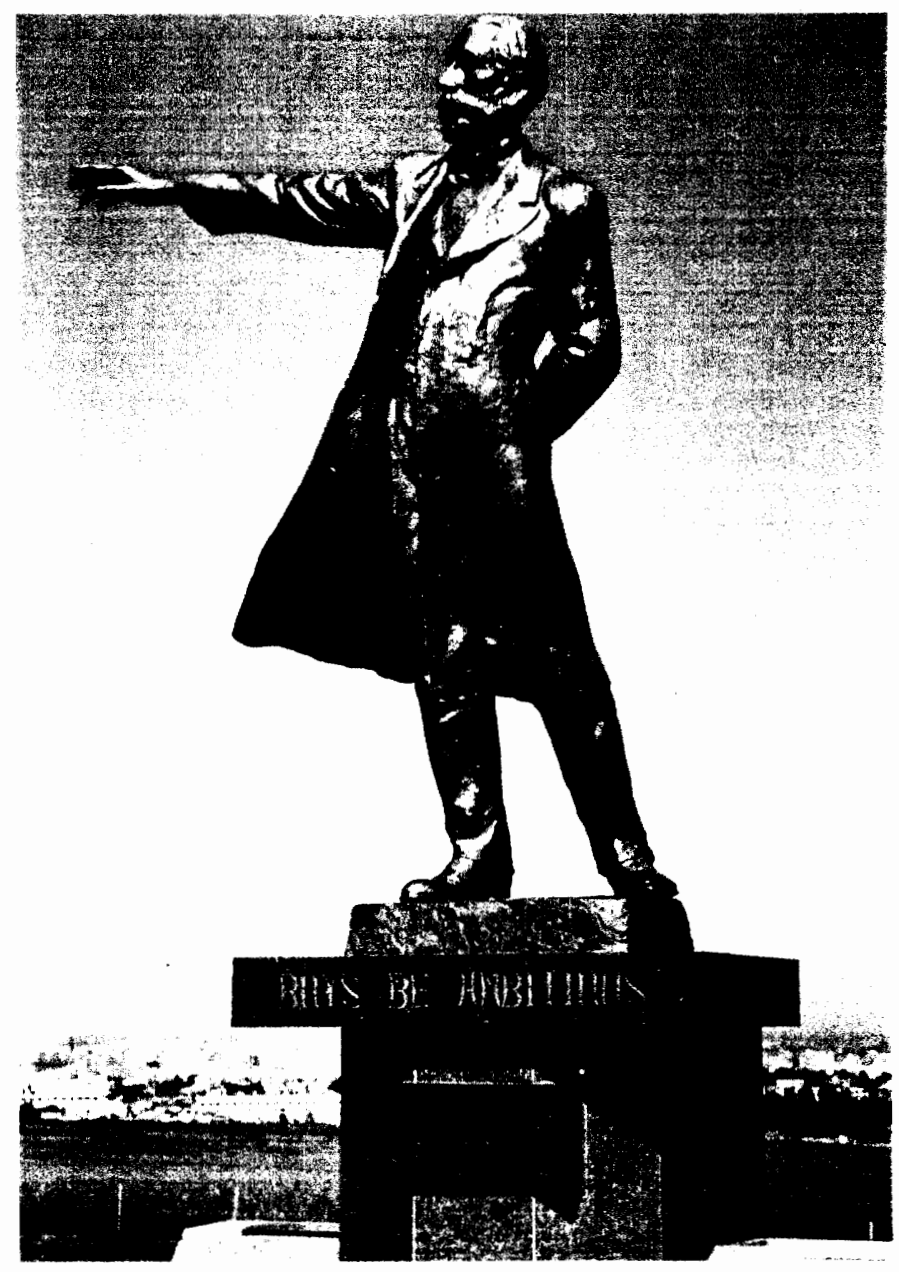

Figure 2. The statue of William Smith clark at Hitsuji Ga Okatenbodai, in Sapporo, Hokkaido. 


\section{THE PROCESS OF FINDING AN INSTRUCTOR AND THE EVENTS THAT LED TO THE CONTRACT BETWEEN CLARK AND THE KAITAKUSHI}

The Meiji leadership was interested in an instructor not only knowledgeable in scientific agriculture, but who was also a moral leader. Kuroda knew from experience the problems produced by lack of discipline among students and would not make the same mistake again. He was simply interested in an American who had values and could relay them to the students of Hokkaido.

Clark possessed two characteristics that qualified him for the task in Hokkaido: an unwavering dedication to teaching and academics, and combined christian ethics and science, which were to become important in the way he approached education in Hokkaido.

\section{THE SEARCH FOR CIAARK}

The search for instructors, and the decision to hire clark, was a process of accidental links and professional relationships that finally led to the decision that clark was the most qualified person for the position.

On May 9, 1871, Capron wrote Clark from Hokkaido that he had a "Japanese youth of high rank, to recommend [to] the 
Massachusetts Agricultural College,"52 the same college that clark, a few years before, had helped found and of which was now acting president. Capron went on to explain:

The young gentleman is bright, intelligent, understands English, has a fair Japanese education, and is nineteen years of age. Mr. Mori [Mori Arinori] expressed some fears that you may have no preparatory courses in which to prepare him for the regular curriculum. It has occurred to me that perhaps in a case so peculiar - one even of national importance, and which might also prove of prospective advantage to your institution - you might relax something of the stringency of your regulations for admission, or at least manage to take charge of the preparatory instruction of this youth. I shall esteem it a personal favor if you can accommodate the views of Mr. Mori. ${ }^{53}$

Clark knew Capron through previous correspondence and was glad to accommodate the Japanese student. Clark's cooperation with Capron and Mori was his first link with the Kaitakushi and his eventual work in sapporo.

The student's name was Naito Seitaro and he was the first student sent by the Kaitakushi to the Massachusetts Agricultural College. In 1869, while living in Japan, Naito had stayed in the home of Mori while attending school and was a close friend of the then charge d'affaires in Washington. Naito was an outstanding student at the Massachusetts college and later traveled with clark to Sapporo where he acted as his official interpreter.

Naito was joined his first year by three other students:

Maki, William Smith Clark, Chapter v, p. 7. 
Geamon Yuchi, Ichisuke Nomura, and Inataro Yamao. Naito stayed at the college for three years and during the commencement exercise in 1872 gave an address entitled "Progress in Japan," in which he outlined the basic needs of Japan both morally and industrially. In 1872, Naito was visited by Mori at the Massachusetts Agricultural College. The two strolled around the campus until they came to the top of a hill overlooking the college military drill field. Mori stopped and watched the students engaging in military training and said: "That is the kind of an institution Japan must have, that is what we need, an institution that shall teach young men to feed and defend themselves."54 His enthusiasm led to closer attention being paid to the Massachusetts Agricultural College for the consideration of foreign employees, and reaffirmed the belief that the Massachusetts college should be used as a model in Japan.

Mori staked much on Western style education and was often criticized as being too liberal, although later, as Minister of Education, he believed education was to suit the purpose of the state, not to foster independent thinking, and became a conservative proponent of nationalized education.55 Mori's main opponent was Motoda Eifu (1818-1891) who believed liberal educational values from the west were destroying the

54 Ibid., Chapter V, p. 11 .

55 Herbert Passin, Society and Education in Japan (New York: Teachers College and East Asian Institute, Columbia University, 1965, ) p. 86. 
traditional Confucian moralism which fostered devotion to the emperor and loyalty to the state. Although slightly more radical, Motoda's thinking was similar to Sakuma Zozan (18111864), who believed Eastern morals should be taught alongside Western science for the betterment of Japan. ${ }^{56}$ Motoda eventually won, however, when Mori was assassinated by ultranationalists.

Niijima $\mathrm{JO}^{57}$ (1843-1890) also played a role in the eventual discovery of clark. Niijima came to the United States after befriending an American captain who let him stow away on his ship until they reached Boston. Once in Boston, Niijima traveled to Amherst where he enrolled in the Massachusetts Agricultural College as the first Japanese to attend the college. Even though Niijima had fled Japan illegally, he was persuaded by Mori to be an interpreter for the Iwakura Mission in $1871 .{ }^{58} \mathrm{Ni}$ ijima was a representative

56 Donald H. Shively, "Motoda Eifu: Confucian Lecturer to the Meiji Emperor," Confucianism in Action ed. David S. Nivison and Arthur F. Wright (Stanford, California: Stanford University Press, 1959.) p. 302-333 passim.

57 Niijima (also Niishima Jo or Reverend Joseph Neeshima) was a samurai from the Annaka domain. After fleeing to the United states Niijima converted to Christianity and was ordained. Upon returning to Japan he founded the Doshisha, or "Society of Like Minds." In $1877 \mathrm{Ni}$ ijima started an English and Women's school of the same name. After Niijima's death Doshisha developed into one of Japan's leading Christian Universities stressing spirituality in education and sharply criticizing the state run education of Japan. (Hunter, Concise Dictionary of Modern Japanese History, p. 146.)

58 The Iwakura Mission, led by Prince Iwakura Tomomi and including such figures as Kido Koin, Okubo Toshimichi and Ito Hirobumi, left for the United States and Europe to try and 
of the Massachusetts Agricultural College and another link between clark and the Kaitakushi. Niijima later became an outspoken advocate of liberal, Christian education and was greatly influenced by clark. The university he established later became a focus of liberal education and contributed to intellectual development in Meiji Japan.

After the Iwakura Mission left the United States emptyhanded, Mori was put in charge of a project collecting information concerning education in the United states and compiling the data for the use of the imperial government. Mori had become a key figure in the formulation of a national education policy in Japan. ${ }^{59}$ He sent letters to leading educators in the United states, including clark, asking opinions on five basic issues concerning the importance of education and national development. Mori asked how education affected the following aspects of statehood: "Upon the material prosperity of a country, upon its commerce, upon its agricultural and industrial interests, upon the social, moral, and physical conditions of its people, and its influence upon the laws and government. "60

revise treaties and study the Western nations. Although treaty negotiations were unsuccessful, the group did learn a great deal from the west. The data that the group accumulated while in the United states and Europe helped to formulate Japanese policy on how to deal with western encroachment.

59 Hall, Mori Arinori, p. 12-13.

60 Mori Arinori to William Clark, February 3, 1872, The William S. Clark Collection, Archives and Manuscripts Department University Library, University of Massachusetts at 
Mori compiled and published the responses in a book titled Education in Japan, and although Clark's response was not included, those of many of the nation's top educators were. Birdsy Grant Northrop, a Yale Theological school graduate and secretary of the connecticut state Board of Education sent a letter to Mori and his response, though short, was published. Northrop and Mori became friends and although Northrop declined an invitation to become chief advisor to the Ministry of Education in Japan, he became increasingly interested in Japanese affairs and in 1873 started a ten-year effort to repay the indemnity the shogunate had paid the United States following the Shimonoseki Incident of $1862-1863 .{ }^{61}$

Northrop was involved in the negotiations between Clark and the Legation of Japan, but it is difficult to determine exactly what role he played in clark's contract with the Kaitakushi. During the negotiations, the Legation told Clark that they were interested in acquiring his services for two years but clark, confidently, told them he could accomplish the same amount of work in one.

Amherst.

${ }^{61}$ In 1863, after the shogunate failed to expel the foreigners under Choshu pressure, Choshu leaders ordered the bombing of Western ships passing through the straits at Shimonoseki. In 1864, British, U.S., French, and Dutch ships attacked Shimonoseki and landed troops. A treaty was quickly signed by the choshu clan and the foreign powers. The incident shifted choshu attention away from the expulsion of foreigners to the ousting of the shogunate. 
On February 12, 1876, three years after Mori had returned to Tokyo and was replaced by the new Charge d' Affaires in Washington, Yoshida Kiyonari, Clark received a letter from the Legation expressing Yoshida's wish to have clark oversee the establishment of the Sapporo Agricultural College. Yoshida explained to clark that the "Japanese government will pay to you in consideration of your services, for a period of one year, the sum of seven thousand and two hundred 'gold yen equal to your currency." "62 The exchange rate being roughly one U.S. dollar to one Japanese yen, Clark stood to make seventy five percent more than the four thousand dollars a year he received as president of Massachusetts Agricultural College.

Clark came to the attention of the Kaitakushi through tenuous links between Japanese and American officials, Clark and the Massachusetts Agricultural College's reputation, and the vision that certain Japanese possessed as to how education should be pursued by the Meiji government. The programs of the Massachusetts Agricultural College were well-suited to the needs of the Kaitakushi and Kuroda considered himself fortunate to have the services of the founder of that institution.

62 Yoshida Kiyonari to william Smith Clark, February 12, 1876, William S. Clark Collection, Archives and Manuscripts Department University Library, University of Massachusetts at Amherst. 
CLARK, HIS STAFF, AND THE CONTRACT SIGNED

The contract that Clark signed on March 3, 1876, consisted of three sections that pertained to clark, and five to the Kaitakushi. First, clark was to serve the imperial government in "the capacity of Assistant Director ('President' is inserted here in Clark's handwriting, initialed by Yoshida) and Professor of Agriculture, Chemistry, Mathematics and the English language, at the Sapporo College, Hokkaido, Japan, under the management of the Kaitakushi."63 Secondly, clark "further agrees to and covenants to devote himself to the duties of instruction, under the regulations of the College," "64 and work at least six hours everyday, "excepting Sundays, and special resting days announced by the Japanese authorities."65 Thirdly, clark, while working for the Kaitakushi in Sapporo, "will not engage in any trade or commerce, either directly or indirectly."

The imperial government, in return for clark's services, paid him seven thousand two hundred yen and provided "a

63 Contract of Employment between Yoshida Kiyonari, Legation of Japan and William Smith Clark, March 3, 1876, William S. Clark Collection, Archives and Manuscripts Department University Library, University of Massachusetts at Amherst.

$\begin{array}{ll}64 & \text { Ibid. } \\ 65 & \text { Ibid. } \\ 66 & \text { Ibid. }\end{array}$ 
suitable house for his residency."67 The Japanese government also specified that by "mutual consent, this contract may be cancelled, upon a notice of three months, by either party."68 Further, the Japanese government agreed "to defray the necessary expenses attending. - passage from Amherst in Massachusetts U.S. to Sapporo, Hokkaido,"69 and provide return passage to Amherst at the expiration of the agreement. The Japanese government also agreed to pay "all the traveling expenses for the said Clark, and one servant, whenever traveling beyond the limits of sapporo city,"70 for either official business or pleasure.

Through the international cooperation between the Kaitakushi and the United States, the Japanese had learned to take precautions while hiring foreign employees. The last provision of the contract reads:

The Japanese government reserves the right to dismiss immediately the said clark, should he neglect to perform his duties, disobey the instructions of the Kaitakushi authorities, or commit any act unsatisfactory to the said government, and in that event, is to pay the compensation, to the date only of such dismissal, and the return passage should not be paid by the said government."17

The last section of the contract is clear, and is

67 Ibid.

68 Ibid.

69 Ibid.

70 Ibid.

71 Ibid. 
testimony to the fact that perhaps the imperial government, when employing foreign specialists, had not obtained valuable service on every occasion. In the Japanese version of the agreement, clark's official title was "head teacher," significantly different from "president," the title which Clark referred to himself as in his letters. In the English translation of the contract, the word "president" was inserted after the title "assistant director" by clark, and the change was initialed by Yoshida. Maki explains: "It was fortunate that Clark's relationship with the Kaitakushi and its officials were always of the best so that a possible conflict over the duties of a 'president' as compared with those of a 'head teacher' never occurred."72

Two of Clark's students accompanied him to Washington to sign contracts of their own. In the original letter from Yoshida, the Legation expressed an interest for "the services of two other professors,"73 at Sapporo College, and the choice was Clark's. He chose william wheeler and David Penhallow, both outstanding students at the Massachusetts Agricultural College.

On January 12,1876, Clark, referring to himself in the third person, wrote a letter to the Board of Directors at the Massachusetts Agricultural College submitting that because

\footnotetext{
72 Maki, William Smith Clark, Chapter V, p. 19.

73 Yoshida Kiyonari to william Smith Clark, February 12 , 1876.
} 
"for more than eight years he has devoted his energies to the work of the college and intends to keep his connections with it, "74 he be permitted one year's absence from the duties of president. Clark explained that "the Japanese government, having resolved to establish an Agricultural College, with the Massachusetts College as a model, has requested him to select a faculty, books, and apparatus, and advise concerning its location and organization."75 clark believed that a "furlough for this useful and honorable mission, might be granted him, not only without detriment but with positive advantage to the Massachusetts College," and for this reason, "he respectfully asks leave of absence from May 15, 1876 to September 1, 1877."176

The Board of trustees agreed and Clark and his two travel companions, which later included William P. Brooks who signed a two year contract to be superintendent of the sapporo College Farm but did not arrive in sapporo until February, 1877, received a warm farewell party, which included a musical serenade. The trip to Sapporo began on May 21, 1876, when Clark and his two students caught a train in Philadelphia that took them across the United states to San Francisco.

74 William Smith clark to the Trustees of the Massachusetts Agricultural College, January 12, 1876, William S. Clark Collection, Archives and Manuscripts Department University Library, University of Massachusetts at Amherst.

75 Ibid.

76 Ibid. 
To the Japanese, Clark was a man of "superior character." It is now necessary to briefly describe how this character developed, and why clark's thoughts on education and teaching were so appealing to Mori, Kuroda, and others.

\section{CLARK'S EARLY LIFE IN NEW ENGLAND}

Clark's life to the point of the establishment of the Massachusetts Agricultural college and the Sapporo Agricultural College made him the best man for these tasks. He was the first graduate of Amherst College to go abroad and obtain a Ph.D., he served in the Union Army with distinction, and was dedicated to the practical application of chemistry to agriculture and ethics to education. These characteristics, combined with Clark's sense of moral mission, became the philosophical foundation for the creation of the Agricultural College.

Clark was born in a pleasant, white house in the small country town of Ashfield, Massachusetts, on July 31, 1826. In 1835 Clark's father, Dr. Atherton Clark, sold his medical practice in Ashfield and moved into a larger and more comfortable house in Easthampton, Massachusetts. Clark attended Secondary School in Easthampton, where he became acquainted with Samuel Williston, an event that played a major role in his life. ${ }^{77}$

williston was a successful business person in the

77 Maki, William Smith Clark, Chapter I, p. 9. 
Easthampton area and among other interests was the button and suspender kingpin of Massachusetts. Williston was also interested in christianity and education. On February 22 , 1841, he was granted a charter for the establishment of the Williston Seminary. Construction began in June, 1841, and classes were held on December 2, 1841. Among the first onehundred and ninety-one students was clark. Clark graduated from the Seminary in 1844. Among his other contributions to education, williston gave a substantial amount of money to Amherst college, which led to the subsequent construction of Williston Hall and a chemistry laboratory. By the time clark entered Amherst College he was married to Harriet Keopuolani Richards williston, Williston's daughter, and spend the majority of his time in Williston Hall using the chemistry laboratory. It was not surprising that clark entered Amherst College, his father-in-law having shown such a profound interest in the college and education in general.

During Clark's stay at Amherst College he experienced a religious awakening that stuck with him for the rest of his life. The views on religion that he developed while at Amherst College manifested themselves, especially while in Hokkaido, in all tasks that he performed. His enthusiasm for religion colored his deeds in moral tones, and endowed him with a sense of righteousness that lent purpose to his work. clark wrote to his mother from Amherst College on March 16, 1846: "Your prayers for a long lost son are as I humbly hope 
and trust answered. This blessed night, five hours since I believe I submitted to my redeemer. Pray for me that I may not be deceived with a false hope for that is certain death."78 Clark was always a devout believer, but the Christianity that he brought to sapporo, and the later sapporo Independent Christian Church which he helped establish, was endowed with his strong belief that religion was a foundation for further education. He believed that christianity should not be used as an absolute guiding principle, but a moral foundation for the further attainment of knowledge.

\section{THE DEVELOPMENT OF AN ACADEMIC}

Clark's interest in science, specifically chemistry, and later mineralogy and botany, progressed and by $1847 \mathrm{Clark}$ was published in the American Journal of Science and Arts, a favorably recognized journal in the scholastic community. clark not only used his interest in science as the foundation of his education, but to pay for it as well. While in Amherst, he collected rare mineral samples and gave them to the college collection as a means to help pay for his university education. His senior year Clark was admitted into Phi Beta Kappa, and was regarded as one of the leading young minds at the college. In 1848, upon graduation from Amherst College, Clark accepted a teaching position at williston Seminary and taught science there until 1850.) He channeled

78 Ibid., Chapter II, p. 7. 
his enthusiasm for science and religion into teaching and by 1850 it seemed natural that clark sought a career in education. ${ }^{79}$

In 1850, clark, desiring to further develop his training in mineralogy, decided to attend Georgia Augusta University in Gottingen, Germany (Clark was the first graduate of Amherst College to obtain a Doctoral Degree of Philosophy in Chemistry.) On October 21, 1850, Clark arrived in London and visited the Royal Botanical Gardens at Kew where the Victoria Regia, a large marsh flower, caught his attention, and kindled his interest in botany. Some years later clark described the experience in a speech. Because he was so taken by the beauty of the Victoria Regia, his "plan of operation was changed so that instead of seeking my fortune in the mining regions of the far west, I became in due time a teacher at Amherst." clark went on to suggest that the beauty of the flower was so compelling that it sparked his interest in agriculture and botany and his eventual concern in the creation of an agricultural college. Clark said:

My connection with the agricultural college resulted directly from the opportunity there offered to begin the accomplishment of my botanical purpose; and already my heart's desire to look upon the flowers of the victoria unfolding their beauty and exhaling their fragrance in my own country. ${ }^{81}$

79 Ibid., Chapter II, p.19.

so Ibid., Chapter II, p. 28.

81 Ibid., Chapter II, p. 28. 
In Germany, Clark developed his own thinking on the method and value of education. Some of Clark's most interesting thoughts were based on the growing conflict between science and Christianity. Although in the nineteenth century the ideas were still fairly compatible, a philosophical rift was beginning to form, and clark, a young scholar who embraced both concepts, found interesting ways to make the two ideas complimentary. Clark believed that "happy indeed will that land be where true spiritual religion shall be combined with the highest attainments in learning!"82 He attempted to implement these early thoughts in the organization of the Massachusetts and Sapporo Agricultural Colleges.

Clark furthered his belief in the creation of a workable unity between these conflicting ideas by suggesting that this unity "will one day be done, and I believe, in America first; for though Christianity and science are by no means incompatible, the former must be firmly established among a people, before they are exposed to the flood of evil influences resulting from the pride, false delicacy and excessive refinement of unsanctified knowledge." ${ }^{3}$ For clark, before people were submitted to the blinding light of science, a spiritual foundation must be created, based on the moral code specified in christianity, so that the newly

82 Ibid., Chapter II, p. 34.

83 Ibid., Chapter II, p. 34. 
acquired knowledge, raging like a bolt of wild energy in the scholar's grasp, did not lead to intellectual abuses.

clark applied much of this early thinking to the development of Hokkaido. Clark believed that with the moral training received from the Bible, scientific learning, like agriculture, botany, and mineralogy, could then be expanded upon, creating the best-educated person.

On May 2, 1852, Clark wrote his parents from Berlin: "I have finished my studies at the Georgia Augusta University and said 'farewell' to Gottingen for a long, long time."84 In fact he bid Europe good-bye forever, as he never returned. Clark's Doctoral dissertation was titled The Chemical Composition of Metallic Meteorites and it was enough to grant him a Ph.D. in chemistry.) As one of the few academics in Massachusetts to have such a degree, he achieved considerable distinction. On October 12, 1852, Clark was named Professor of Analytical and Agricultural Chemistry and instructor in German at Amherst College. He was the only faculty member at Amherst College who had a Ph.D., and soon after his arrival at the college the Science Department was established and clark played an active role. By 1860, in the words of Professor Maki, Clark was "well established both as an academician and a citizen of the town." 85

(Clark served in the Civil War where he showed courage and

84 Ibid., Chapter II, p. 37.

85 Ibid., Chapter II, p. 52. 
sound principle about the purpose of the fighting (see Appendix B). He returned to Amherst from service in June, 1863, and at a banquet held at Amherst College was asked to give a speech on the war. At first he lamented the deaths of two of his closest friends, but then he addressed the more historically important issue of slavery, and his thoughts are worth noting. According to a reporter who was present, clark explained that "slavery had received a death wound, it was poisoned and would never recover. The negro had demonstrated that he was a man -- that he could take care of himself." 86 clark went on to say that this "war has settled one thing -- the manacles could never be riveted upon the slave again. Too many of them had been made free -- too many of them had been armed, and drilled, and taught to love freedom to never again be made bondmen." 87 Clark, in as eloquent a speech that can be found during this period, ended by saying that by "fighting the rebels he was striking a blow, not so much for the old flag as to rid the land of the curse of slavery."s8

In respect to Clark's thoughts on education, the war cemented Clark's appreciation of discipline and military training at the Massachusetts Agricultural College and the Sapporo Agricultural college. He believed that the discipline of military training fostered sound minds that could be

86 Ibid., Chapter III, p. 22.
87 Ibid., Chapter III, p. 22.
88 Ibid., Chapter III, p. 23. 
trusted with the future of a nation.

ESTABLISHING THE FOUNDATIONS FOR PRACTICAL AND MORAL EDUCATION IN HOKKAIDO

Once in Amherst, Clark turned his attention to education, specifically in the field of agriculture. Although Clark was never trained in agriculture, Amherst, and many of the other small, rural towns that dotted the New England countryside, were completely dependent on agriculture.) (n 1859, Clark had been appointed a member of the state Board of Agriculture. The board wielded substantial political power and possibly as a result, in 1860, and then after the war in 1871-72, Clark was made president of the Hampshire Agricultural Society.'

(During his presidencies of the Hampshire Agricultural Society, Clark stressed that agriculture should become more scientific and that the best means to this end was education.) (Clark wanted to combine his training in chemistry with agriculture so that his degree and expertise would have practical application. He believed that if agriculture could be made more scientific, labor could be made less strenuous and fields, through the use of fertilizers, could have greater yields. For the purpose of educating people along these lines, and for the betterment of the community in general, Clark understood that best way to achieve results was through the creation an institution that specialized in vocational 
training, and also taught basic values. ${ }^{89}$

On July 2, 1862, Senator Justin S. Morrill of Vermont introduced the Morrill Act to the Congress of the United States. The bill provided for the allocation of money to states for the creation of vocational institutions that contained military training as part of the curriculum. On April 29, 1863, the General Court in Massachusetts passed an act similar to the Morrill Act providing funds for the establishment of a vocational college. Clark played an important role in the decision to have the Massachusetts Agricultural College built at Amherst. He was made professor of horticulture and botany on February 6,1867 , and on August 7, 1867, was elected the first active president of the college, Clark was hailed by Louis Agassiz of Harvard as the most qualified person for the presidency. Agassiz wrote in a report given to the state Agricultural Commission:

Professor clark is the most suitable person for the present position. This is shown by his profound scholarship and experience, and especially by his personality in relation to education. There is no doubt that any student would be greatly influenced by witnessing President Clark's devotion to education. ${ }^{90}$

Soon after the Massachusetts Agricultural College was founded, it established a reputation in scholastic circles. In 1873, Clark and several of his staff jointly submitted a

89 Ibid., Chapter IV, p. 1-3.

9o Hokkaido Prefectural Government, Foreign Pioneers, p. 73. 
study titled Circulation of Plant Sap, which was hailed by science journals as "a revelation to physiological botanists. The Massachusetts State Agricultural College has established a splendid position in the academic world."11)

In his third annual report to the college, one year before he was made president, clark proposed that the Massachusetts Agricultural College be an institution that brings out the "full dignity of men."92 In this report clark began to combine moral training with the vocational education offered at the agricultural college. Clark wrote that the "foundation stones of republicanism or democracy, as distinguished from aristocracy, are the ideas of EQUALITY, PROGRESS, and the dignity of LABOR,"93 and that the Agriculture college would, through fostering these ideals, empower the students with these values. Clark stated that the purpose of the college was "to diffuse education and property among all the people, to give as nearly as possible every child an even start in the world, and an equal chance to be president, member of congress, farmer, or mechanic as he may chose."94 Clark went on to say that "equality in education, in wealth, in power, so far as God has permitted, is the keystone to the arch of liberty, which our fathers

91 Ibid.

92 Maki, William Smith Clark, Chapter IV, p. 16.

93 Ibid., Chapter IV, p. 16.

94 Ibid., Chapter IV, p. 16. 
established. As men who believe in these things, not as mere glittering generalities, but as vital, practical, eternal truths," 95 clark believed that education was more than just practical instruction, but the very foundation on which human liberty was based. These early thoughts that he made a part of the Massachusetts Agricultural College's mission later became reality in Hokkaido.

\section{CONCLUSION}

The early experiences of Clark's life, from his graduation from williston Seminary, the discovery of christ at Amherst college, and the formulation of educational beliefs in Germany, to the blood-stained fields of the civil war and the creation of the Massachusetts Agricultural College, clark was constantly in the process of developing a philosophy that mixed the rationality of science with the necessity of a strong, moral education that he thought, if applied correctly, was the best possible form of social development. After Clark was hired to serve the Kaitakushi, he applied these thoughts successfully and developed the Sapporo Agricultural College along practical and moral lines.

95 Ibid., Chapter IV, p. 17. 


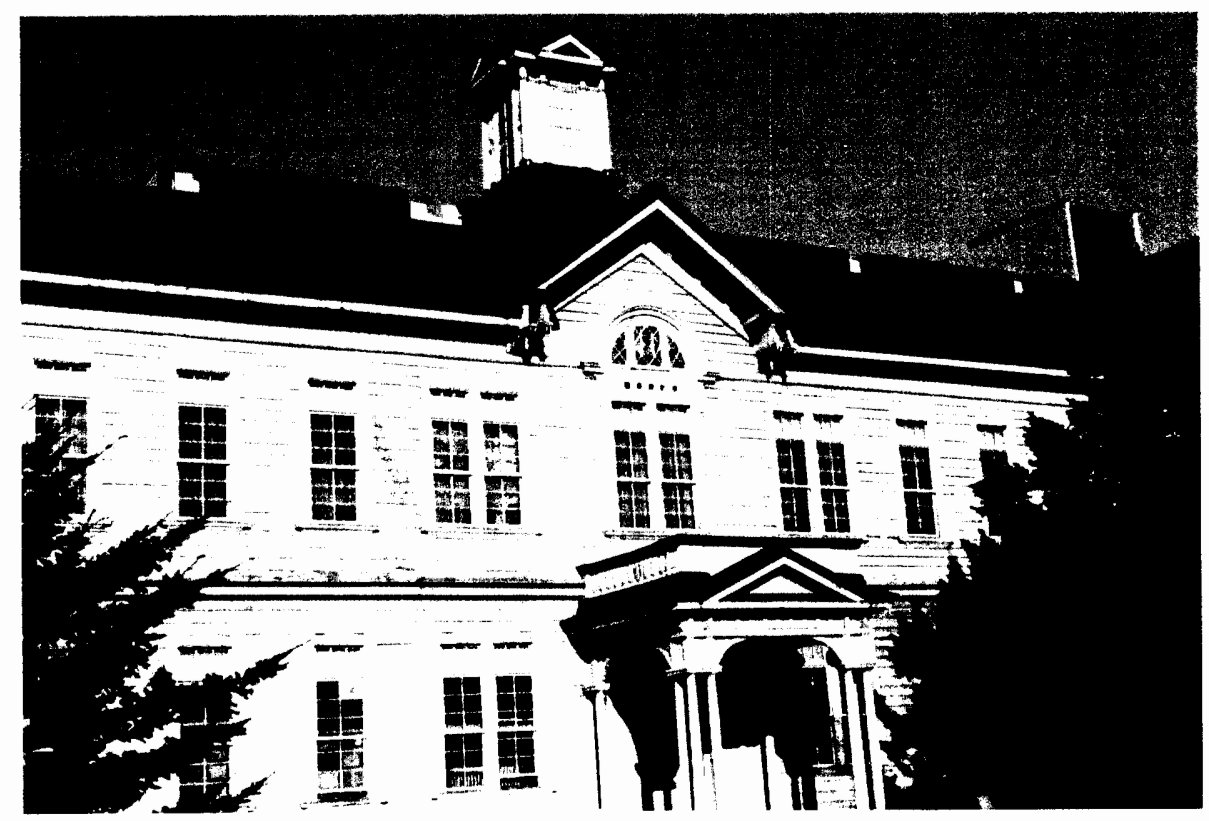

Figure 3 . The original building of the Sapporo Agricultural College, Sapporo, Hokkaido . 




Figure 4. The first class at the Sapporo Agricultural College with Professors Clark, Wheeler, and Penhallow. (William Smith Clark Collection, Archives and Manuscripts Department University Library, University of Massachusetts at Amherst.) 
THE ACCOMPLISHMENTS OF CLARK AS FOUNDER OF THE SAPPORO AGRICULTURAL COLLEGE

After signing the contract in Washington clark left for Hokkaido. He brought with him Professors Penhallow and Wheeler and the accumulation of thoughts on education that he had developed throughout his career. He applied himself to the duties of president of the Sapporo Agricultural College and his achievements were monumental.

Clark accomplished three things as a college president: he founded the Sapporo Agricultural college and endowed it with a sense of purpose, he reorganized the experimental farm in sapporo so that it would better accommodate the needs of the college, and he erected the college barn and other structures that became a symbol of progress in Hokkaido, and a model for future development in Japan. Clark accomplished all this in eight months and to the complete satisfaction of the Kaitakushi.

THE JOURNEY TO JAPAN AND INITIAL DESCRIPTIONS

On June 1, 1876, aboard the steamship Great Republic, the three New Englanders left San Francisco for Tokyo. En route to Japan, Clark studied Japanese characters trying to better his teaching skills. Clark claimed to have learned forty 
seven characters in one day, and given the vigor with which he pursued any task, this is not likely an exaggeration.

On June 28, 1876, the Great Republic arrived in Tokyo Bay, and the three men were provided a room at the International Hotel in Yokohama. While in Yokohama, clark was visited by his old student Naito Seitaro and several other officials. The men made preparations for the trip to Tokyo and Naito acted as interpreter.

The next afternoon the three boarded Japan's only train, which stretched across the beautiful Kanto plain between Yokohama and Tokyo, and made for the capital. Clark was taken by the fertile soil, and small, but well-cared-for rice plots that dotted the landscape like hundreds of small mats put out to dry. They arrived at Shimbashi station in Tokyo and were taken to the Seiyoken Hotel in a two-horse, covered carriage which, as most officials traveled by jinrikisha, or "handpulled carts," was quite a luxury. The seiyoken Hotel was famous for housing foreign guests, and a place where European banquets and other occasions were held. On June 30, 1876, Clark and his two friends were received by Kuroda, and under the cover of a jinrikisha proceeded through the pounding rain towards the Tokyo headquarters of the Kaitakushi. With Naito as interpreter, Kuroda and Clark had much to discuss and the two, no doubt having much in common, hailed the initial meeting a success. ${ }^{96}$

96 Maki, William Clark Smith, Chapter V, p. 26. 
While at the Seiyoken Hotel, Clark was visited by the steward of the Uesugi family, whose younger son had studied at the Massachusetts Agricultural College. According to Clark, the steward brought a gift and opening it, placed "a pair of superb antique vases and a piece of the richest white silk crepe and begged me to accept them as a token of regard from my visitors."97 After the presentation of the gifts, Clark was escorted, with Naito at his side, to the "finest restaurant in the city in the new public park just opened by the government in the famous cemetery of the tycoons." 98 While at dinner, clark was received by Uesugi himself, who Clark described as the "old Daimyo," and heir to the Uesugi estate. Following dinner clark was given more gifts including "a nice lacquered chest wrapped in a white silk cloth and bound with heavy green silk bands."100 In the chest were "nineteen pieces of the finest antique lacquer work"101 Clark had ever seen. This sort of overwhelming hospitality marked nearly every moment of his stay in Japan.

On July 3, 1876, Clark dined with Mori and Kuroda at

97 William Smith Clark to Mrs. Harriet Clark, July 5, 1876, William S. Clark Collection, Archives and Manuscripts Department University Library, University of Massachusetts at Amherst.

$\begin{array}{ll}98 & \text { Ibid. } \\ 99 & \text { Ibid. } \\ 100 & \text { Ibid. } \\ & \\ 101 & \text { Ibid. }\end{array}$


Mori's American-style home near the seiyoken Hotel. On July 4, Clark and his two friends were treated to a "glorious centennial fourth"102 at the Mori residence and were accompanied by "about fifty Americans, ladies and gentlemen, Mr. Mori and other Japanese officials."103 The celebration was "furnished with music by a military band of the government, had a grand salute of 101 guns and a blaze of Japanese fireworks."104 The celebration was all to clark's liking except for the traditional Japanese music which clark described as "simply horrible,"105 and he went on to suggest that it was "not written and never ought to be."106

Through clark's brief stay in Tokyo it is easy to understand just how profound the changes in Japanese society were. It had become a sign of sophistication to be viewed as cosmopolitan in once-isolated Japan. Clark was so absorbed in the generosity of the Japanese people that he feared he may be "killed with kindness,"107 before he had a chance to complete any work for the Kaitakushi. He found time to examine nine potential students for the sapporo college, whom he found "sufficiently advanced to enter the freshman class of the
102 Ibid.
103 Ibid.
104 Ibid.
105 Ibid.
106 Ibid.
107 Ibid. 
Agricultural College to be established at Sapporo."108 In fact, clark was always impressed by the students he encountered while in Japan. He wrote to his brother, referring to students that he had interviewed to attend the college: "they read and understand English very well and write it better than most of our students."109

on July 10, 1876, Clark and his two companions had the privilege to observe the Kawabiraki, or the "opening of the river," a festival that was held on the sumida River. clark wrote to his wife:

Near a famous bridge thousands of boats laden with tens of thousands of men, women, and children and gaily illuminated with brilliant parti-colored paper lanterns assemble in one dense mass. A grand display of fireworks blazes forth from the bridge and the people in the boats respond with rockets and fireballs, music and cheers. The houses along the banks of the river are also illuminated and crowded with spectators. Altogether the scene this year was beautiful beyond all the power of language to describe. ${ }^{110}$

On July 21,1876, clark had a rare opportunity to view Emperor Mutsuhito. Although foreigners had been in audience

108 William Smith Clark to Kaitakuno Haigan Yasuda, July 5, 1876, William S. Clark Collection, Archives and Manuscripts Department University Library, University of Massachusetts at Amherst.

109 William Smith clark to Capt. William B. Churchill, August 5, 1876, William S. Clark Collection, Archives and Manuscripts Department University Library, University of Massachusetts at Amherst.

110 William Smith Clark to Mrs. Harriet Clark, July 23, 1876, William S. Clark Collection, Archives and Manuscripts Department University Library, University of Massachusetts at Amherst. 
with the Emperor before, including Capron, Clark was fortunate enough to view the Emperor in his natural environment, among his subjects (Appendix C).

While in Tokyo, Clark, Penhallow, and Wheeler were given a tour of the Imperial Library by Professor Veeder, a senior faculty member, and visited the Imperial college of Engineering. The three men were impressed by the massive volume of Japanese, Chinese, European, and American works so much that wheeler wrote: "although the institution is but three years old, it is equal in design, as it undoubtedly will be in accomplishments, to any in the United States."111

A week prior leaving for Sapporo, Clark was fortunate enough to travel to Shimoda, forty miles from Tokyo, and observe the extensive farm land, and study what was considered modern techniques in raising sheep. ${ }^{112} \mathrm{Clark}$ referred to the trip in a letter he wrote to his sister after having arrived in Hokkaido. clark considered himself fortunate to have had such an "excellent opportunity to observe the agricultural practices of that portion of Japan,"123 and went on to give a fairly lengthy description of what he saw. The description

111 Maki, William Smith Clark, Chapter V, p. 31.

112 William Smith clark to Kaitakuno Chiyokan Kuroda Kiyotaka, July 15, 1876, william S. Clark Collection, Archives and Manuscripts Department University Library, University of Massachusetts at Amherst.

113 William Smith Clark to Mrs. S.W. Leete (My Dear Sister Belle), August 5, 1876, William S. Clark Collection, Archives and Manuscripts Department University Library, University of Massachusetts at Amherst. 
gives some indication of the variety of crops that the Japanese harvested.

The low lands are covered with rice fields extending as far as the eye can reach like the corn fields of Illinois. On the uplands were seen crops of sweet potatoes, Irish do., turnips, eggplant, radishes, cabbages, cauliflower, hemp, flax, ropeseed, wheat, barley, Indian corn, etc.. The tillage is all done by hand and is nearly perfect. Two crops are grown annually, wheat, barely, etc. in the winter and millet, upland rice and vegetables, etc., in the summer. ${ }^{114}$

On July 30, 1876, after traveling up the Japan Sea, the three men arrived in otaru, about twenty miles northeast of Sapporo. Clark's arrival, however, was stained by tragedy when, trying to announce the arrival of clark Kuroda fired a salvo of cannon from the Gembu Maru, Kuroda's ship, against the cliffs just outside the small town. Unfortunately for the family living in a home just above the cliff, one of the rockets went wild and smashed into the small, wood dwelling mortally wounding one woman. ${ }^{115}$ The next day, July 31, 1876, clark's fiftieth birthday, the three men made their way on horseback to sapporo.

\section{CLARK'S ARRIVAL IN SAPPORO}

clark's arrival in Sapporo, riding at a breakneck pace through the rocky, dirt streets astride a black horse, trying to outride his two younger companions and his one Japanese

\footnotetext{
114 Ibid.

11 Maki, William Smith Clark, Chapter V, p. 35.
} 
interpreter, set the tone for his active, and hurried stay in Hokkaido. Clark, Wheeler, and Penhallow, followed by the tentative Naito, traveled from Otaru to Sapporo. Otaru is a city still renowned for its beauty with cobblestone streets and stone bridges that arch over a romantic canal lined with a mixture of European and traditional Japanese buildings that teeter dangerously on the edge of aging streets. The route from otaru to Sapporo is an old, treacherous road along the Japan Sea, but the view is wonderful.

About halfway to Sapporo the men stopped at a small tea house to drink what wheeler described as the "ever-present tea." They rested for an hour before continuing for Sapporo. As Wheeler explained in a letter to his mother, about eight kilometers outside Sapporo, Clark, Wheeler, and Penhallow, all skilled equestrians, broke into a speedy pace, with the fifty year old clark in the lead. Wheeler had initiated the race because earlier, while in Otaru, Clark had expressed a curiosity as to how it felt to be fifty years old and wheeler took it upon himself to demonstrate such a feeling and show Clark his age. Wheeler explained to his mother that clark, even after the horse race, was "very active and youthful in appearance for a man of his years."116

After entering Sapporo the three men were housed at the honjin, or "headquarters," which was a building used in the Tokugawa period to quarter visiting dignitaries who happened

116 Ibid., Chapter VI, p. 1. 
to make it so far north. According to a letter from clark, the building had none of the luxuries that one might expect from a building that was used to house important political figures, but was spacious and simple. The honjin was built along the Soseigawa, a river that runs through the heart of Sapporo. Although the Soseigawa stills runs its course, the honjin no longer stands, as it was destroyed by fire shortly after Clark's departure. Clark told his sister Isabelle in a letter written on August 5, 1876, that he had "had a delightful journey to this distant and peculiar country and experienced very few even of the ordinary discomforts of travel."117 Clark went on to boast that all "our expenses have been paid in the most liberal manner during the past ten weeks and we have been treated everywhere with the greatest consideration."118

In the same letter clark described the city of sapporo. His description gives some indication of what the northern capital looked like over a century ago, during its initial development.

This city was founded five years ago as the capital of Hokkaido, which includes Yezo and the Kurile Islands. It was laid out by American engineers with broad, straight streets and already contains 8000 inhabitants. It is situated on a level plain which is well watered by numerous streams from the heavily wooded mountains on the west. The river Toyohira runs along the eastern side of the city

117 William Smith Clark to Mrs. S.W. Leete (My dear Sister Belle), August 5, 1876. 
and supplies water for a canal which connects with the Ishikari. There is an abundance of water power and already mills for manufacturing wood, grain, silk, iron etc., are in full operation. ${ }^{119}$

In the same letter to his sister, clark described the honjin as follows:

Our compound or yard consists of an entire square about 300 feet long and 100 feet wide and is surrounded on all sides by a tight wooden fence nine feet in height surmounted by pointed palisades. The buildings are constructed in a mixed style of architecture, one third Japanese, one third American and one third German. The rooms are all on the ground floor, and there are neither chimneys nor cellar. We intend to erect chimneys before winter. We each occupy a suite of three rooms opening into each other and also on the veranda which extends around the building and is closed at night and in cold weather with shutters and windows. A janitor with wife and child lives in the servants quarters, and takes care of the outside matters. We employ a cook and two servant boys and live in very comfortable style. Our greatest annoyance so far consists in the necessity of using condensed milk and canned fruits, as this strange people, who do almost everything as we do not, have no liking for milk, butter or cheese and eat all their melons, pears, peaches, plums and apples perfectly green in which condition one kind is as good as another. ${ }^{120}$

clark's concerns about the fruit were short-lived. The Kaitakushi, under the directions of Kuroda, imported fruit trees and planted them at the experimental farms and in Sapporo. Clark cheerfully explained to his sister that since the work of Kuroda and Capron "several thousand apple, pear, peach, apricot, plum and cherry trees are now growing finely

119 Ibid.
120 Ibid.


in the park around the capital in this city."121 Also, the Kaitakushi made attempts to further distribute and manage timber in Sapporo. Clark wrote that under the direction of Youchi, a former student of Clark's at the Massachusetts Agricultural College, three million trees had been sent to Sapporo from the experimental farm in Nannai. According to Clark, Youchi's experimental farm "contains 15,000 acres and is worked by 430 men with their wives and children at an annual expense of $\$ 40,000$. How does the connecticut experimental station at Middletown compare with that?"122

Impressed with the progress that Hokkaido had made in the short period it was under the auspicious control of the Kaitakushi, clark wrote that it was "most surprising to see what has been done by a few men like General kuroda (now only 35) for the improvement of Japan in the last seven years."123 Although clark had not seen Hokkaido before the Meiji Restoration, by traveling throughout the land, and observing with detail the things he encountered, the fascinating balance of the old mixed with the new, the international mixed with the native, clark was able to get a taste of the progress that Japan was making. The Kaitakushi programs were only a decade old, and had not touched all aspects of Hokkaido, and clark was able to observe the settlement of Hokkaido in motion, and

$\begin{array}{ll}{ }_{121} & \text { Ibid. } \\ 122 & \text { Ibid. } \\ 123 & \text { Ibid. }\end{array}$


thus his observations are valuable.

Clark wrote to his brother william on August 5, 1876, that his trip to sapporo had gone well and that not "only have all my requests been granted at once, but a thousand favors I had no right to expect have been freely bestowed upon me by the highest officers of the government."124 It was this spirit of international cooperation that set the development of Hokkaido apart from similar international efforts.

Within the first several weeks, clark also took a trip to inspect the coal mines at Sorachi with Kuroda. Although Clark did not comment on the mines themselves, or the working conditions there, he did write appreciative words about Kuroda, and the relationship that the two men were starting to foster. Clark realized early that Kuroda was a remarkable man. Clark recorded his trip to Sorachi in a letter to his wife:

I had a most delightful emersion with the governor and had a splendid opportunity of becoming intimately acquainted with his private and public life and his views on many subjects of education, politics and religion. He is a very remarkable man and is in many respects of admirable character. Though born a poor boy and trained only as a private soldier he has become one of the ablest statesmen and generals of the empire. He is now thirty six and had secured for himself and descendants after him a pension for eminent services in the civil war. He is now Major General in the regular army, one of the seven members of the imperial council selected by the Mikado, and

124 William Smith Clark to Capt. William B. Churchill, November 19,1876 . 
chief of one of the ten departments of government. ${ }^{125}$

The relationship between Clark and Kuroda, though professional, was close and cordial. The two men found many things in common. They had both served in the military, and fought in what their governments referred to as civil wars. They both believed that education was fundamental to the development of a nation and that science and technology, combined with sound moral training, was the best way to educate young citizens. The two men shared a philosophical likeness that kept their relationship on good terms, even after clark returned to Massachusetts.

THE OPENING OF THE SAPPORO AGRICULTURAL COLLEGE

On August 14,1876 , the opening ceremonies were held for the Sapporo Agricultural College. That same day Clark wrote a letter to his wife describing the events:

The ceremony occurred this morning at $100^{\prime} \mathrm{clock}$ in the college building in front of which was erected a beautiful arch of evergreens and flowers. Gov. Kuroda arrived at the hour named and was conducted into the main hall, where were assembled the students, clad in neat buff uniform. Behind the students stood the officers and employees of the Kaitakushi. On the right of the governor were stationed Director Jushio (Zusho), the President and Faculty, and on the left of His Excellency were army officers and invited guests, including two Americans. No one was permitted to sit but the governor. The exercise consisted first of an

125 William Smith Clark to Mrs. Harriet Clark, August 14, 1876, William S. Clark Collection, Archives and Manuscripts Department University Library, University of Massachusetts at Amherst. 
address from the governor which was read, according to Japanese custom by an officer. Secondly, an address from Director Jushio was read in a similar way by another officer. All this in Japanese lingo. Then the voice of a Yankee was first heard in the land as the President stood and began in magnificent western style, "Your Excellency, Mr. Director, Officers and students of the Sapporo Agricultural College, and gentleman, \&\&\&\&\&." As it was a extempore effort and no interpreter could follow him, the orator had it all his own way, and if he failed to do full justice to the occasion it was his own fault and he alone might bare it. His name was Smith. Then was read the address of vicegovernor Hori and, finally, the sentiments of the students were duly expressed by one of their number. We next proceeded in a cheerful frame of mind to partake a collation spread in an adjoining building. The President had a seat on the right of the governor and they both agreed that as far as they knew everything was lovely and they could perceive no difficulty. ${ }^{226}$

Clark told his wife, giving her a glimpse of what his schedule had been like since arriving in Japan: "thus ends three months since I left dear old Amherst. I have struck the first blow, and with due moderation we now think of beginning to assign recitations the day after tomorrow and the next day we intend to actually begin operations."127

Although clark claimed his speech was extemporaneous, either he wrote it down later, or had jotted down his thoughts beforehand, because the speech is available. Although he spoke to a small, but growing group of frontier intellectuals, his words were well thought-out. They demonstrate two very interesting points: one, that clark, although in a limited

226 Ibid.
127 Ibid.


way, knew that his role was to help shape the country by providing its people with a liberal education that would free them from the historical bonds of authoritarian rule; and two, by expressing his philosophy to the eager ears of young Japanese, he laid a philosophical mission for the Sapporo Agricultural College. Many people were involved with the establishment of the college, but only clark voiced what he saw as the educational mission of the college, and thus found himself a special place in the hearts of Japanese who yearned for the freedom and social mobility of which he spoke. It is for these reasons that Clark, above all other people, is still identified with what is now Hokkaido University. Simply, Clark gave the College purpose:

The establishment and maintenance of schools and universities are justly regarded as the most imperative duties of any enlightened government, but it is very remarkable that while institutions for the promotion of agriculture and the mechanic arts have only recently received due consideration in Europe and America, His Excellency Governor Kuroda has founded first of all in Hokkaido a college of agriculture. May its eminent success demonstrate the wisdom of his policy.

We who have been called to constitute the first board of instruction here will zealously do our part in our noble and inspiring vocation. We will by our example and our teaching endeavor to develop in the young men who may become our pupils those qualities of mind and heart which will best fit them for usefulness in life. ${ }^{128}$

Clark went on to say:

This wonderful emancipation from the tyranny of caste and custom, which in ages past has enveloped like a dark cloud the nations of the East, should

128 Maki, William Smith Clark, Chapter VI, p. 9-10. 
awaken a lofty ambition in the breast of every student to whom an education is offered. Let everyone of you, young gentleman, strive to prepare himself for the highest positions of labor and trust and consequent honor in your native land which greatly needs your most faithful and efficient service. Preserve your health and control your appetites and passions, cultivate habits of obedience and diligence, and acquire all possible knowledge and skill in the various sciences which you may have an opportunity to study. Thus you will prepare yourselves for important positions, which are always in waiting for honest, intelligent, and energetic men, of whom the supply is uniformly less than the demand in this as in every other country. ${ }^{129}$

It is not difficult to surmise that this speech, though spoken to a group of Japanese leaders who might have understood a few, if any, of the words, were hardly casual utterances. His words were probably understood by, and largely directed towards, the students, who took them very seriously. Many members of the first class, several years after they had left the Sapporo Agricultural College and distinguished themselves in different fields, could quote Clark's inspiring words exactly. Clark's words were prophetic in the sense that many of the students did distinguish themselves, and the Sapporo Agricultural College went on to produce some of Japan's leading thinkers.

Clark believed that the Sapporo Agricultural College could open minds, and as a consequence the doors of social mobility, in Japan. Using Kuroda as an example, Clark stressed that it was up to the individual as to how much might 
be achieved. Clark believed that education could aid in the destruction of "caste and custom" in the East, and learning was like a great wind that would blow away the black clouds of government not determined by the people. He stressed the liberal qualities of the institution, along with its practical mission in Hokkaido.

It was important to the students of Hokkaido that Clark was an American. He embodied the concept of freedom and enterprise and the words that he spoke must have seemed more sincere to the people who were raised in a time of such radical social change. Thus with the same vigor that clark applied himself to the establishment of the sapporo Agricultural College, the students applied themselves to their studies, paving the way for the success of the college.

\section{CLARK TAKES OVER THE SAPPORO EXPERIMENTAL FARM}

In a letter that clark wrote to Kuroda on September 8 , 1876, he suggested that, among other things, the sapporo Agricultural college, in order to better acquaint its students with the proper skills to effectively utilize the land and resources of Hokkaido, create a model farm. Under the supervision of clark, the farm would be worked and managed by students. The project was one of Clark's most successful ideas while in Sapporo, and contributed to an already growing reputation that clark, although only contracted to be the president of the Sapporo Agricultural College, was willing to 
do much more for the people of Hokkaido. The experimental

farm idea was not new to Hokkaido, but under the supervision of Clark, and the management of the Sapporo Agricultural College, the farm became more successful than ever. Clark wrote to Kuroda:

I have the honor herewith to transmit, in accordance with your request, a few suggestions concerning certain desirable improvements in connection with the work of the Kaitakushi at this place.

First. For the proper training of the students of Sapporo Agricultural College in practical agriculture, and especially in the correct mode of farm management, with due regard for economy of labor, the production of profitable crops and stock, and the maintenance of fertility in the soil, I recommend that a well-equipped farm be placed under the exclusive control of a foreign professor of agriculture, who shall be under the direction and authority of the President of the college. He shall be competent to lecture upon Agriculture and all its branches, and shall, as a member of the college faculty, give such instruction both theoretical and practical, as may be required by the President. He shall in January of each year prepare an inventory in detail of all the stock, farm produce, implements and other property under his charge, with the cash value of the same; and an estimate of the experiments, and accompanied by a detailed statement of the plan of operations proposed for the ensuing season. The inventory and estimated thus prepared shall, when approved by the President, be submitted by him to the proper officers for the necessary appropriations, and no draft beyond the amount granted shall be made by the superintendent upon the treasury. .

The most rational and approved system of farm economy should be adopted, only such crops and stock should be raised as are likely to be worth their cost, and as far as practical hand implements and human labor should be replaced by agricultural machines and the working of horse and cattle.

Experiments with new crops, fertilizers and machines, as well as with manufactures such as silk, sugar, beer, vinegar, \& will of course be exceptions to the above general rules, but should 
always be conducted in the outset upon a moderate scale. ${ }^{130}$

Clark used the college farm in Massachusetts as a model for the idea that he proposed in Hokkaido. Clark suggested that the farm be under his supervision, but that management and labor be supplied by students. Kuroda, quick to understand the long-term benefits of such a suggestion, responded in less than a week, approving the college farm and putting the whole operation under the control of clark. Clark was given the old experimental farm originally established by Capron in Sapporo.

As was mentioned earlier, the Kaitakushi had attempted to build a farm for the purpose of agricultural development. Many of the Japanese, stuck firmly in the traditional ways of farming, were unwilling to experiment, however, and the farm had failed to achieve its purpose. Kuroda thought that if clark gave attention to the project, and had the farm under his authority, the idea might have new strength, and thus approved the suggestion. Kuroda wrote to Clark on September 12, 1876, four days after clark suggested creating the model farm:

The Sapporo government farm was established for the purpose of furnishing the people a model in agriculture. After consultation with General Horace Capron some years ago, sufficient experiments in producing various crops, raising

130 William Smith Clark to His Excellency Kuroda Kiyotaka, Kaitakuno Chokuwan, September 8, 1876, William S. clark Collection, Archives and Manuscripts Department University Library, University of Massachusetts at Amherst. 
livestock and general farm management, have been made to demonstrate the adaptation of these things to the climate and soil of Hokkaido. As, however, the customs and ideas of the older time are yet prevalent, the general introduction of new methods is difficult.

Therefore, I now transfer the said farm to the Sapporo Agricultural College; and I desire to establish upon it the best possible system of agriculture, and to substitute for all the old Japanese habits the best foreign style of farming, which, being perpetuated, will accomplish my original object.

Accordingly, I direct you, bearing in mind the above facts, to manage the affairs of said farm as your best judgement may dictate. ${ }^{131}$

THE REORGANIZATION OF THE SAPPORO EXPERIMENTAL FARM TO BETTER SUIT CLARK'S ECONOMY OF AGRICULTURE

Two weeks later, on september 23, 1876, Clark wrote to Kuroda that in order to most effectively take advantage of the Kaitakushi's generous offer to the college, the farm would not only have to be better-organized, but expanded, and partially relocated, in order to accommodate what clark saw as the most effective means of farm economy. clark wrote:

I beg permission respectfully to represent that any rational system of foreign farm economy supposes a farm to consist of three divisions, viz., Land for tillage, for pasture, and for timber. This division of an estate is especially necessary in a new country where there is always a want of good markets for ordinary farm products.

The land assigned to the college farm is all that could be desired for tillage, while the 50,000 tsubo [one tsubo=5.3 sq. meters] of uncultivated land, if taken between the farm and the canal on

131 Kaitaku Chokuwan, Kuroda Kiyotaka to William Smith Clark, President of the Sapporo Agricultural College, September 12, 1876, William S. Clark Collection, Archives and Manuscripts Department University Library, University of Massachusetts at Amherst. 
the north east will answer every purpose for woodland. A good pasture from 50,000 to 100,000 tsubo of open land, as near as possible to the farm is indispensable to a proper management of the business connected with it. It is no use to produce large crops of hay and grain in sapporo without having animals with which to utilize the same. The livestock, fed at small cost during the summer, should be kept and, if necessary, fattened upon the farm produce in winter, while their manure, carefully preserved and applied to the tillage lands should be used to maintain the fertility of the soil.

In order therefore to accomplish these objects and establish a proper system of agriculture, I respectfully ask that a convenient pasture be added to the gift already bestowed upon the college. Also, I beg in order to greatly improve the farm that a slight change be made in the boundary so as to include a part of the small stream and lowland near the farm buildings on the Western side. This addition while deducting nothing of value from other property would increase largely the worth of the estate. Without it, I see no way to locate a suitable barn, or to have proper conveniences for keeping stock. . .

In making these requests I have no personal ends to subserve, but am actuated wholly by a desire to secure such an adjustment of matters as will result in the highest success of all Your Excellency's undertakings. ${ }^{132}$

On September 23, 1876, Kuroda wrote Clark explaining that

his requests would be granted and that the land desired was in the process of being located, and that Clark, as supervisor, had final approval over the selection. Five days after clark expressed a need to expand and alter the model farm, the Kaitakushi granted him the requested area for uncultivated land, and were in the process of locating the land for stock.

132 William Smith Clark to His Excellency, Kaitaku Chokuwan, Kuroda Kiyotaka, September 22, 1876, William S. Clark Collection, Archives and Manuscripts Department University Library, University of Massachusetts at Amherst. 
Kuroda wrote to Clark:

You wanted a pasture ground, besides 159,000 tsubo strong of the farm ground 50,000 tsubo of uncultivated land which you received from the capital yesterday. I have ordered to the capital to deliver a government land, not exceeding 50,000 tsubo which shall be selected in a place where there is no hindrance, so that you will consult with them after examining the locality. ${ }^{133}$

Kuroda also accepted the proposal concerning the small stream and brought the model farm up to the standards that Clark originally submitted. Kuroda appropriated 85,351 yen for the reorganization of the farm. ${ }^{134}$ Clark understood that in the developing agricultural economy of Hokkaido the model farm would have to be self-sustaining in order to survive. The farm, as originally established, produced almost exclusively produce, and was unable to survive if demand was low, or if production was slowed. Clark had become a convincing force in the Kaitakushi, and although he possessed only the authority that came with being president of the college, the respect he commanded let him secure any program, regardless of economic burden or otherwise, with the government of Hokkaido.

Concerning his new duties, and his relationship with the

${ }^{133}$ Kaitaku Chokuwan, Kuroda Kiyotaka to William Smith Clark, Vice Director of the Sapporo Agricultural College, September 23, 1876, William S. Clark Collection, Archives and Manuscripts Department University library, University of Massachusetts at Amherst.

134 Hokkaido Imperial University, Semi-Centennial of the Hokkaido Imperial University, Japan 1876-1926 (Sapporo, Hokkaido: Hokkaido Imperial University, 1927), p. 16. 
Kaitakushi, Clark wrote his wife expressing his satisfaction with the way he was being treated and the progress of his mission in Hokkaido. Clark told his wife of the special relationship that existed between him and Kuroda and speculated that he might be the only foreigner in Japan entrusted with such wide ranging, and relatively unchecked authority. With respect to many of the accounts that are available from people who went to Japan as government employees, Clark's speculation is not altogether unreasonable. clark wrote to his wife:

My health is excellent, my work abundant and not above my capacity, my employers are liberal and appreciative, and my achievements satisfactory to myself and so far as I know to the government. I believe I am the first foreigner who has been entrusted with entire control of valuable property, with full power to buy and sell, employ and discharge help, build and make improvements, and draw money from the treasury with my official seal, without the slightest supervision from a Japanese officer. ${ }^{135}$

The Kaitakushi already had a person in mind to fill the position of farm superintendent, W.P. Brooks, who had been with Clark in Amherst. In a letter from Director zusho, speaking on behalf of orders issued by Kuroda, Clark was informed that the Kaitakushi was interested in employing Brooks for the position and that Clark was to make the arrangements. "The Kaitakushi," wrote Zusho, "desires to engage the services of Mr. W.P. Brooks, of whom we spoke to you a few days ago at the Sapporo Agricultural College, as

135 Maki, William Smith Clark, Chapter VI, p. 22. 
Professor of Agriculture and Farm Superintendent for a term of three years."136 Zusho also specified, in order to make the farm more productive, that Brooks "bring with him sufficient Massachusetts seed corn for one hundred acres and grass seed for fifty acres of the quality best suited for this climate."137 Thus was the beginning of Brooks' three year experience in Sapporo.

THE BARN AT THE SAPPORO AGRICULTURAL COLLEGE

At the end of september, clark sent architectural plans to Kuroda for a new barn to be built on the sapporo Agricultural college campus. The plans were drawn up by Wheeler and the architecture was modeled after the farm buildings of New England and was no doubt foreign to Japanese builders. The barn was large, about fifty by one hundred feet with a cellar for storing manure, a ground floor for stock, and an upper level to store grains and hay. The barn, though originally difficult to build, later became a model, as did most creations by clark while in Japan, and many of the barns throughout Hokkaido were built using the Sapporo Agriculture College model. The original barn still stands and is a National Cultural Treasure. Although worn and falling apart,

136 Kaitaku Shiohangwan, Zusho Hirotake, by order of General Kuroda to President William Smith Clark, September 11 , 1876, William Smith Clark Collection, Archives and Manuscripts Department University Library, University of Massachusetts at Amherst. 
it is testimony to the achievements of Clark while in Japan. The creation of the model barn was, as Nitobe describes, a "stroke of practical wisdom on the part of Dr. Clark deserving of all praise."138

The construction of the barn meant a great deal to clark, who wrote in a letter to Vice Governor Hori Motoii on September 29, 1876, concerning the finances needed to build the structure, that if the barn was constructed by the time he left Japan, his mission to Sapporo, and all that he undertook, would be considered a success. Clark wrote:

The erection of a suitable barn for the shelter of fodder, stock and manure is of course an extra expense which must have your special sanction, and which I hope may be decided upon as soon as possible, since the plan of farm operations for the ensuing year must depend largely upon its decision. There can be no question that the annual savings effected by its construction will be equal one half its entire cost. In order to feel any real satisfaction with the condition of the Sapporo Agricultural College upon my return to America I must see the proposed barn ready for use by the first of June next year. If that is accomplished I shall be satisfied with the results of my mission. ${ }^{139}$

It might seem that clark staked too much of his mission upon the construction of the barn, but clark believed if the college was to be successful it must make every attempt to improve its infrastructure and shed the tired skin of Japanese

138 Nitobe, The Imperial Agricultural College, p. 9-10.

139 William Smith Clark, Director Sapporo College Farm to Kaitakuno Hori Motoii, September 29, 1876, William Smith Clark Collection, Archives and Manuscripts Department University Library, University of Massachusetts at Amherst. 
traditional agricultural methods. He was not abusive towards the older ways, in fact he thought they were effective in a limited sense, but the college was to clark an institution which specialized in modern farming, something that if to be realized, needed his speedy attention, and the quick execution of his proposals. If the barn was intact when clark left, which it was, it proved that the Sapporo Agricultural College and the experimental farm, though in their fledgling stages, were at least on the right track. The barn was an agricultural necessity for effective farm management and construction of the barn started immediately.

THE INTRODUCTION OF STOCK, SEED, AND IMPLEMENTS TO THE FARM

On September 27, 1876, clark wrote to Hori that in "accordance with orders received, I have the honor respectfully to present the following requisition for live stock, vehicles, machines and other implements for the use of the college farm."140 For livestock Clark listed: "4 pairs nambu horses for teams, 2 good horses for work or saddle, 4 nambu bulls for teams, 2 red short horn cows, 2 red short horn heifers 2 years old, 4 grade cows or heifers, [and] 1 short horn bull 2 years old." 141 As agriculture moved forward,

140 William Smith Clark, Director of Sapporo College Farm to Kaitakuno Hori Motoii, September 27, 1876, William S. Clark Collection, Archives and Manuscripts Department University Library, University of Massachusetts at Amherst.

141 Ibid. 
technology became the key to success and to clark the human labor in Japan was a cruel reminder of the backwardness of Japanese practices. Clark also made detailed lists of carts, wagons, and other implements that the Kaitakushi needed to buy before the experimental farms could be considered up to date. clark sought to completely reequip the college farm so that the students came into contact with not only the management and educational value of having a well-equipped farm, but also the tools to perform manual labor to develop their work skills that to clark were essential to personal betterment. The Kaitakushi must have been excited about clark's personal interest in equipment, but the students, young samurai from Tokyo who were probably unfamiliar with tools like the manure fork, had to have been less enthusiastic.

\section{PROPOSED IMPROVEMENTS TO HOKKAIDO AND THE SUGGESTION OF AN AMERICAN SETTLEMENT}

In the letter clark wrote to Kuroda in which he originally suggested the college farm, he included, among others ideas, what he considered improvements in the living conditions of Hokkaido. clark believed to the end that the purpose of a stronger agricultural system was to better the lives of the people. Along with the college farm clark included other suggestions that are worth noting. Although there is no evidence to suggest that, like the college farm, any of these ideas were swiftly executed, they do give a close 
look at what clark considered some of the inadequacies of Hokkaido's settlement at the time of his stay. Clark wrote to Kuroda:

I would respectfully call attention to the fact that the style of building dwelling houses and barracks in common use here is altogether inappropriate for the climate.

Every human habitation in Hokkaido should stand at least two feet above the general level of the surrounding ground and should have under its main part a cellar not less than six feet deep in the clear. This would insure suitable drainage and promote cleanliness around the building, and contribute greatly to its warmth, while the cellar would furnish for vegetables and other articles beyond the destructive influence of frost.

Every dwelling house should also have a chimney of brick or stone and one or more cheap cast iron stoves. Warmth for the household, convenience in cooking and economy of fuel, would thus be secured, while the health of the people would not be injured as at present by the poisonous exhalations of burning charcoal. The necessity for openings in the roof and the injurious effects of smoke upon the eyes and lungs would thus be obviated.

Every house should have windows of glass instead of paper, in order to reduce to a minimum the amount of openings in the walls for the admission of light. Glass of the cheapest sort would admit twice as much light as the same surface of oiled paper, and besides being vastly more durable would retain the heat much better. ${ }^{142}$

clark continued on to the subject of clothes. Japanese clothing, especially around the rural areas of Sapporo, was made of rice straw. Considering the pounding that Hokkaido received in the winter, these clothes were wholly inadequate. Sapporo can receive a foot of snow as early as November, and the northern land remains white, receiving as much as ten feet

142 William Smith Clark to His Excellency Kuroda Kiyotaka, Kaitakuno Chokuwan, September 8, 1876. 
of snow in some areas, well into the spring. Clark wrote concerning the inadequacies of Japanese clothing:

In regard to the food and clothing of the people some change seems indispensable. That clothing of wool, boots and shoes of leather, and a considerable amount of animal food, are practically necessary in this climate for the preservation of vigorous health and the capacity for outdoor labor during the winter, the history of all other nations in similar latitudes demonstrates. ${ }^{243}$

These descriptions by Clark, of paper windows and straw cloths in a climate somewhat like Chicago, give an indication of where Hokkaido stood one decade after the settlement.

During Clark's journey up the Ishikari with Kuroda, to inspect the coal mines of Sorachi, Clark and Kuroda discussed the possibility of creating an American colony on Hokkaido to be used as a model for community development, and how labor, agriculture, and other activities should be organized in order to most effectively develop and extract natural resources. That Kuroda, a military figure well aware of the Western threat towards Japan's sovereignty, was willing to suggest an American colony in Hokkaido is testimony to the impact that Western thinking, and the drive for modernization, had had on the young governor and the Meiji leadership in general. The two men must have talked seriously about the prospect because a few days later, in a memorandum written on the subject, clark detailed specific questions in regard to an American settlement. Clark wrote:

143 Ibid. 
Your Excellency having expressed the opinion, during our recent excursion to the Sorachi coal beds, that a colony of Americans would be a most desirable addition to the population of Hokkaido, I beg permission to make a few inquiries and suggestions concerning the matter.

First. Would the Japanese government receive such immigrants upon the condition that they should abjure their American citizenship and become subjects of the Imperial government?

Second. In case such a colony of not less than thirty young men, skilled in Agriculture or some one of the mechanic arts, with their families, should be organized for settlement in the valley of the Ishikari, would the government make them a grant of land in such place as they might select on the public domain?

Third. In consideration of the educating influence of such a colony of active, enterprising and intelligent persons, and the probability that other parties might follow them, would the government provide them a free passage from San Francisco to sapporo and erect for them suitable cheap houses, for which they should pay a moderate rent?

Fourth. Would the government grant such persons exemption from taxation and military service for a term of years, and allow them to constitute a self governing municipality without annoyance from Japanese officers?

Fifth. Would such persons be permitted to engage in trade, manufactures, fishing and mining, and, with all the rights and privileges of other Japanese citizens in all parts of the empire. ${ }^{144}$

clark concluded the list of questions by suggesting to

Kuroda that the "universal depression of business in the

United States renders the present an exceedingly favorable time for attempting such an enterprise, and I am confident that it could be accomplished with the most satisfactory

144 William Smith clark to His Excellency Kuroda Kiyotaka, Kaitakuno Chokuwan, September 12, 1876, William S. clark Collection, Archives and Manuscripts Department University Library, University of Massachusetts at Amherst. 
results."145 Although Clark seemed to have had a favorable impression of the idea, Kuroda, having first mentioned it, cooled to the plan later, and the subject was never mentioned again. The Japanese had never been favorable to the idea of foreign colonization, either from Asia, Europe, or the United States, and part of what was at stake in the race to modernize was the awareness of what had happened to china -- the colonization of a sovereign territory by western powers. Although during the reign of the Kaitakushi, Japan and the United States experienced their best period of international cooperation, an American settlement was apparently one step too far.

That the idea was suggested, however, is evidence of the sincerity of the international cooperation at the time. Kuroda and his American advisors saw the fruits of the present cooperation, and believed that an American settlement would only be a step in the same spirit of internationalism.

Clark and the Meiji leadership believed that for Japan the best tool for education was the model, giving the Japanese something to observe, study, and adopt according to their specific needs. The American colony is the ultimate manifestation of this. Clark was willing to go out of his way to make these models available to the Kaitakushi. When thanked for being willing to tackle tasks outside his original job description, clark responded like a man well aware that 
he, and the people around him, were playing a vital role in the development of Japan. Clark told Hori on December 28 , 1876:

I am specially responsible for the management of the college, yet I shall always be ready, as heretofore, to render any possible service, within the range of my knowledge and capacity, for the benefit of Hokkaido or Japan. Nothing however can be more important to the government or the people, whose interests are identical, than the high mental and moral culture of the rising generation. Through all my future existence it will be a source of rejoicing to me that $I$ was permitted under such favorable auspices to aid in the organization of the Sapporo Agricultural College.

with the deepest gratitude for many favors received, and with most earnest prayers, at the beginning of the New Year, for the continued health and happiness of Your Excellency, and for the longest and truest prosperity of Japan, I remain, very respectfully, your most obliged and most obedient servant. W.S. Clark. ${ }^{146}$

\section{CONCLUSION}

Clark's tenure as president of the Sapporo Agricultural College saw the creation of a modern experimental farm, the construction of the campus barn, and the purchase of a wide range of farm implements to be used at the college. Most importantly, clark gave the college an immediate sense of purpose at the opening ceremonies which proved to be inspiring words to the young students of Hokkaido. As the relationship between Clark and Kuroda improved, Clark was able to advise

146 William Smith Clark to Kaitakuno Hori Motoii, December 28, 1876, William S. Clark Collection, Archives and Manuscripts Department University Library, University of Massachusetts at Amherst. 
Kuroda on not only the college, but internal affairs such as housing, food, and clothing, and even the creation of an American colony on Hokkaido to use as a model to improve the Japanese way of life.

Equally. as valuable for the development of Hokkaido, however, were the ethical and Christian dimensions of Clark's stay in Hokkaido. It is difficult to separate his practical achievements from the moral, as they were intermixed, and the moral aspect of his teaching had a different, but no less valuable effect on his students. 


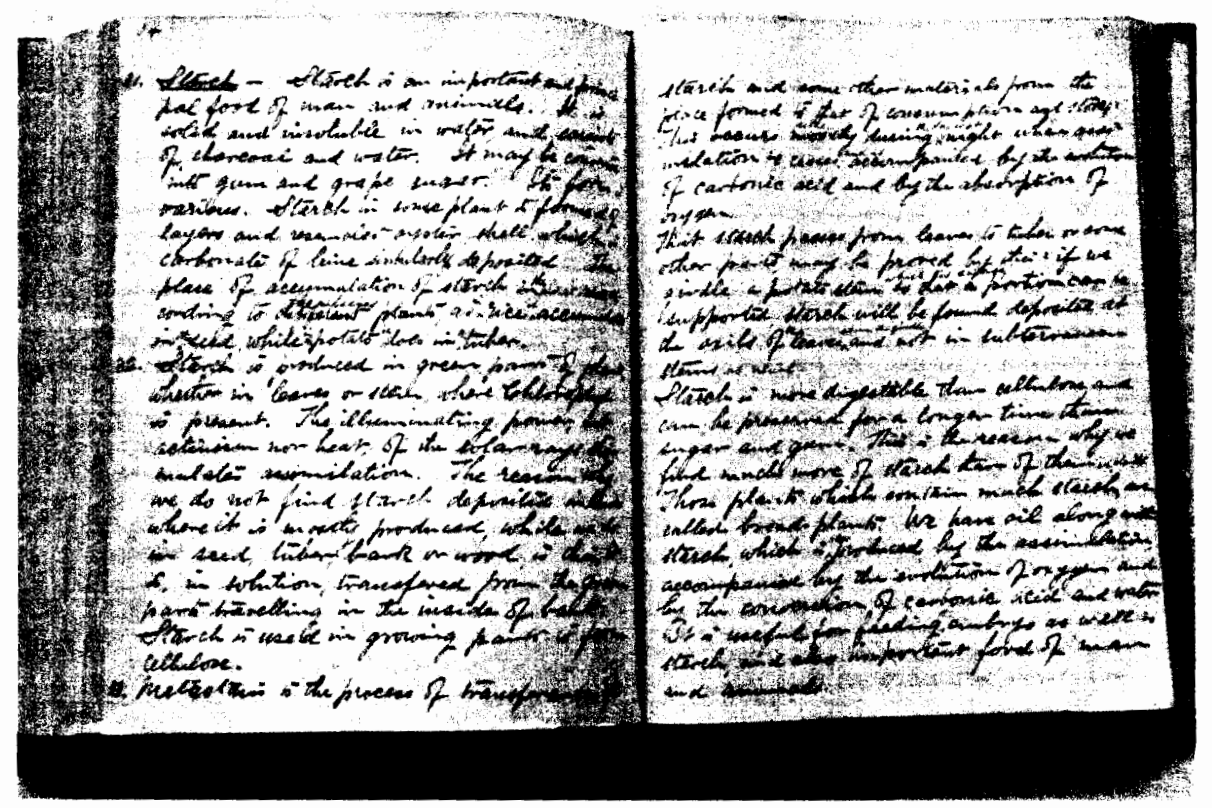

Figure 5. A student's notebook from the Sapporo Agricultural College with corrections made by clark. (William Smith Clark Collection, Archives and Manuscripts Department University Library, Hokkaido University.) 




Figure 6. The barn constructed under the supervision of clark at the Sapporo Agricultural College, now recognized as a National Treasure by the Japanese government. 


\section{CHAPTER V}

LIBERAL AND CHRISTIAN EDUCATION: CLARK'S CONVICTION

While creating the curriculum for the sapporo Agricultural College, clark not only stressed the need for basic agricultural science, but classes that also concentrated on ethical training. This is a less discussed, but equally profound dimension of clark's achievements in Hokkaido. Clark insisted that by using the Bible in and out of the classroom, by creating study groups, and establishing a liberal arts curriculum at the college, the students of Hokkaido would be better prepared for the task that lay ahead.

Many foreign advisors visited Japan during the Meiji Restoration, and many had profound effects on the development of modern Japan. Few, however, equal the accomplishments of clark. He commanded such respect and trust from his students that they wholesale accepted his thoughts on science and Christianity, and embraced them as the creed for what later became known as the "Sapporo Band" in the history of Christianity in Japan. More importantly, however, the students fulfilled Clark's expectations that they become not just well trained tools for the Kaitakushi, but independent thinking "gentleman."

In the contract that Clark signed in washington the only 
duty specified was that of president and head instructor at the Sapporo Agricultural College. The contract did stipulate that Clark obey orders from the Kaitakushi, but there was no hint that clark was to perform duties beyond teaching in a practical sense. In this respect, Clark's contract differed from many other oyatoi kyoshi, or "foreign instructors," as the term normally implied "that they were expected to play a dual role as teachers, in addition to fulfilling their duties as technical specialists assisting in developmental work."147 As has been mentioned, however, Clark volunteered his services for a number of tasks that were not contracted. Clark regarded his stay in Japan as a personal mission, and performed his tasks accordingly. Clark was, as Akizuki Toshiyuki explained, simply "interested in participating fully in the developmental work of the Kaitakushi in Hokkaido."148 The organizations that clark created are further evidence that the Kaitakushi, at least by showing indifference to his work, was also interested in the moral development of its students. The government had something to gain by the gentlemanly behavior of its citizens, and approved of clark's efforts. There was no tension between the Kaitakushi and clark, and there is evidence that Kuroda was impressed with the moral

147 Toshiyuki Akizuki, "American Professors in the Development of Hokkaido: The Case of the Sapporo Agricultural College," Foreign Employees in Nineteenth Century Japan, ed. Edward R. Beauchamp and Iriye Akira, (Boulder, Colorado, San Francisco, California: Westview Press, 1990), p. 229.

148 Ibid., p. 232. 
progress that the students made under the direction of clark's Christian leadership.

\section{DEPARTURE FOR SAPPORO AND THE DISCUSSION OF CHRISTIANITY ABOARD THE GEMBU MARU}

Just prior to leaving Tokyo, Clark met Dr. Luther $\mathrm{H}$. Gulick. Dr. Gulick was one of the first missionaries who came to Japan and was a member of the American Bible Association. During their meeting Clark was given thirty "English Bibles for the use of students in Sapporo."149 Although it may have been Dr. Gulick's intention to have clark contribute to the work of converting the heathen Japanese, Clark used the books to teach ethics in class, despite imperial law forbidding such use of the Bible. Clark did convert many of his students to Christianity, but as will be seen, he was not connected with other missionary activity in Japan.

On July 25, 1876, the Japanese Steamer Gembu Maru left Tokyo for Hokkaido. With the Clark, Wheeler, and Penhallow was Kuroda and a group of Japanese students bound for Sapporo. The students were being transferred from the Temporary School to the new agricultural college in Sapporo. Along the way, the student's behaved poorly and Kuroda threatened to send them all back to Tokyo. Clark and Naito intervened, however, and they were allowed to stay. From this point forward Kuroda asked that clark put special emphasis on moral behavior while

149 William Smith Clark to Mrs. Clark, July 23, 1876. 
teaching in the classroom. ${ }^{150}$ On July 27,1876 , the Gembu Maru anchored off the coast of Hakodate, and enjoyed the night view that the city is still famous for today. Kuroda and clark, using Naito as an interpreter, discussed many topics while steaming towards Sapporo in the northern Japan Sea, but the most interesting conversation was about the use of the Bible as a textbook to teach ethics in the classrooms of the Sapporo Agricultural College. Clark described the conversation in a letter to his brother:

God has given me special favor with governor Kuroda, who is one of the most influential officers of the Imperial government at Tokyo and whose will is supreme in Hokkaido. While traveling with him last summer I conversed with him freely about religion and finally asked leave to use the Bible in the college. He answered that personally he had no objections, but he must forbid it on account of the law and the opinions of the high officials. I told him the Bible was the best of books and was surely to be taught at no distant day in Japan as in all other enlightened countries, and that it would be greatly to his credit to allow its introduction in his new college. He said I could teach its truths to the students, but must not read it publicly nor give them copies for private use. I answered that I was very sorry for I had thirty copies, but that I would obey his orders. ${ }^{151}$

clark met his first obstacle in the form of Kuroda. Kuroda had studied in the United States, however, and was interested in Western culture and so was sympathetic to $76-77$.

150 Hokkaido Prefectural Government, Foreign Pioneers, p.

151 William Smith Clark to Capt. William B. Churchill, November 19,1876 , William S. Clark Collection, Archives and Manuscripts Department University Library, University of Massachusetts at Amherst. 
Clark's request. His paramount concern was that the students at the Sapporo Agricultural College receive the best moral, as well as technological education available. He had seen enough poor behavior on the part of his students, and if the Bible could teach good behavior, he was willing to try. This partially explains why Kuroda later let clark use the Bible both privately and in the classroom. clark continued in the letter to his brother:

About a month after this he sent for me and wished me to teach the students good morals. I replied I could not without constant reference to the Bible and I feared I should give offense. The next day he told me he would withdraw his prohibition in regard to the Bible and I could do as I chose. So I decided to distribute the books and make them useful."152

Then, in a warning that is testimony to the special privilege that clark enjoyed in regard to using the Bible, he told his brother "not to let a word of this get into the papers for it might create a breeze. This you know is the land of the typhoons."153

THE ORGANIZATION AND CURRICULUM OF THE SAPPORO AGRICULTURAL COLLEGE

Prior to the college's opening ceremonies, clark had drafted a detailed schedule for the first term. The schedule 
was drafted for the "exercises of the freshman class,"154 that is, the first twenty-four students that were admitted into the college. The first section listed Botany at $8: 30$ with Clark, Algebra at 9:30 with Wheeler, English at 10:30 with Clark, and Chemistry at 11:30 with Penhallow. The second section, somewhat similar to the first, listed Algebra at 8:30 with wheeler, Botany at 9:30 with clark, Chemistry at 10:30 with Penhallow, and English at 11:30 with Clark. ${ }^{155}$

A breakdown of the four year curriculum that appeared in the First Annual Report (see Appendix D) included courses ranging from Analytical Chemistry, Botany, Astronomy, Manual Labor and Agriculture, to History of English Literature, Extempore Debate, Bookkeeping, Mental Sciences, and Military Drill. In the history of Meiji Japan, Clark is usually categorized as an advisor to agricultural development in Hokkaido, but clearly he exceeded these parameters. Clark proved to be a major force in the introduction of liberal education to Hokkaido, and an outstanding figure in the history of education in Japan.

Although the courses were overwhelmingly scientific, and geared towards the nogakushi, or "Bachelor of Scientific Agriculture," with few exceptions they are hardly

154 Sapporo Agricultural College, First Term Daily Routine by William Smith Clark, 1876, william S. Clark Collection, Archives and Manuscripts Department University Library, University of Massachusetts at Amherst. 
agricultural, and even tend to resemble a liberal arts curriculum. As stressed in the Imperial University of Hokkaido's Semi-Centennial written in 1927:

Thus, with so much emphasis placed on the study of the humanities the college might almost better have been called a college of Liberal Arts instead of Agriculture. One thing is certainly clear, that the graduates in the early years made themselves prominent in different walks of life quite distinct from farming. Many distinguished editors, economists and publicists still living in Japan are the sons of the College in Sapporo. ${ }^{156}$

Osaka Shingo stated in his biography of clark that: "It was true that sapporo aimed at a liberal education rather than at a vocational one, though education for colonization was an object."157 Also, the curriculum pioneered Military Drill as part of the regular requirements. When Mori and Naito had viewed the military drill field at the Massachusetts Agricultural college some years before, it had had a great impact on Mori. Not only did he decide that the Massachusetts model was the best for sapporo, but later when he became Minister of Education, he insisted that military drill be a part of the imperial educational structure. The SemiCentennial stated:

Another pioneer work the college did was to introduce Military Drill in the Institution after the manner of the Massachusetts Agricultural College. This outran Hon. Mori by ten years, for military drill was introduced into the curriculum 14.

156 Hokkaido Imperial University, The Semi-Centennial, $p$.

157 Osaka Shingo, Kuraku sensei Shoden (Tokyo: Maruzen Press, 1956), p. 489 . 
of Normal Schools only when he became the first Minister of Education in 1886 when the cabinet system of government was adopted. ${ }^{158}$

Several weeks later, clark submitted his "Plan of Organization" for the college. This comprehensive sketch, covering everything from the basic educational goals of the college to specifics on admittance, attendance, and discipline, was submitted to Director zusho for his final approval. The text is important because not only does it describe philosophical goals behind the creation of the college, it details the specific areas of study that the founder deemed important.

1. The Sapporo Agricultural College was founded by the Kaitakushi for the education and practical training of young men who are expected to become its employees after graduation and to serve under the direction of the department for the term of five years.

2. The course of instruction will occupy four years, and those students who complete it in a satisfactory manner will receive the degree of Bachelor of Science.

3. The following branches of knowledge will be regarded as important parts of the college curriculum, viz.: The Japanese and English languages; Elocution, Composition, Drawing, Bookkeeping and forms of Business; Algebra, Geometry, trigonometry, Surveying, civil Engineering so far as required in the construction of ordinary roads and railroads, and of works for drainage and irrigation; physics with particular attention to mechanics; Astronomy, Chemistry, with special regard to Agriculture and Metallurgy; Botany, Structural, Physiology and Systematic; Zoology, Human and Comparative Anatomy and Physiology, Geology, Political Economy, Mental and Moral Science, and the most thorough instruction in the theory and practice of Agriculture and

158 Hokkaido Imperial University, The Semi-Centennial, p. 
Horticulture, the various topics being discussed with constant reference to the circumstances and necessities of the farmers in Hokkaido. ${ }^{159}$

In these first three sections of the original plan it is important to note that, like most colleges in the United States, the Sapporo Agricultural College awarded a Bachelor of Science after four years of study. The young men who did manage to graduate were then employed by the Kaitakushi to utilize their skills and further help develop Hokkaido.

Also fascinating was what clark referred to as the "Branches of Knowledge." Although the list may seem like a standard presentation of college offerings, many of these subjects were new to Japan and to the world as a whole, for example Geology, which had suffered for many years under the ball and chain of religion's explanation. In the list of subjects Clark's personal views on education are clearly visible. He was a Christian who had little trouble teaching scientific truths in geology.

Although the list is predominantly scientific, and indeed the college offered a Bachelor of Science, Clark included subjects like business, political economy, and the "mental and moral sciences." It is clear from this list of subjects that Clark's emphasis was on practical knowledge, but not absent was Clark's concern for moral and intellectual growth, an area

159 Sapporo Agricultural College: Plan of organization, by william Smith Clark, 1876, William S. Clark Collection, Archives and Manuscripts Department University Library, University of Massachusetts at Amherst. 
he believed to be critical to the "circumstances and necessities to the farmers of Hokkaido."160 Osaka defined the Sapporo Agricultural College as an institution of "applied science," 161 which is consistent with much of clark's original curriculum.

The next section of the plan stated the "Terms of Admission."

1. Candidates for admission to the Freshman class will be examined orally and in writing upon the following subjects, viz.: Japanese and English languages, which they should be able to read, write and speak with facility; Arithmetic, Geography and History, the knowledge required being equal to that contained in the common higher text-books for public schools.

2. Candidates must be at least sixteen years of age, of sound constitution and good moral character. They must also sign the prescribed form of contract with the Kaitakushi, and furnish a satisfactory surety, residing either in Tokyo or Hokkaido. ${ }^{162}$

These entrance requirements are rather rigorous, although standardized in coordination with Higher School texts at the time. The students were required to understand Japanese, English, Arithmetic and History.

The next section of the plan dealt with "Rank, Examinations, and Removals," at the college.

1. An accurate record will be kept of the deportment, attendance and scholarship of each student.


by William Smith Clark, 1876. 
At the end of each term an examination in writing will be held, and only such students will be allowed to go on with their respective classes as have made satisfactory progress in the studies of the proceeding term, and have been regular in attendance, and exemplary in conduct.

2. Any student who may be removed from the college on account of deficient scholarship or misconduct, or who may leave voluntarily before the expiration of the time stipulated in his contract will be required to pay the cost of his education, as specified in said contract, up to the date of his leaving. . . ${ }^{163}$

There is no evidence that clark ever dismissed a student because of misconduct, or at least he never wrote about it, but clark did dismiss students on account of lack of scholarship. On September 15, 1876, Clark wrote to Director Zusho:

In view of the policy to be adopted in regard to the number and qualifications of students in the college, I recommend the dismissal of Fujita, Hioto, Naito, Shimasu and Takabayashi. This course is rendered necessity by the fact that they are clearly unable to do the work of their class, especially in mathematics. ${ }^{164}$

In the "Spring Report" clark specified that field trips would be a required part of the curriculum. The policy proved to be a great success. Many of clark's students, recalling how he had affected their lives and what they liked most about his style of teaching, specifically referred to the field research. Walking through forests and on mountains, scouring

263 Ibid.

164 William Smith Clark to Director Zusho Hirotake, September 15, 1876, William S. Clark Collection, Archives and Manuscripts Department University Library, University of Massachusetts at Amherst. 
rocks and streams for plant life, and collecting valuable specimens for educational purposes had always been a pleasure for clark, and his students must have equally enjoyed the experience.

Clark explained in his "Remarks," a preamble to the "Spring Report," how teaching ought to be conducted at the college. As usual clark stressed the combination of moral and practical learning as the ingredients of a good education.

The instruction should be as practical as possible in all departments so that the graduates of the college may ever be distinguished for their sound judgment, their enterprising spirit, and their strict morality. Every teacher should make his character and conduct worthy of the imitation of his pupils, and should seize every proper opportunity to impact to them useful information in regard to the care and control of their bodies, the discipline and enrichment of their minds, and the dignity and worth of their immortal natures. ${ }^{165}$

On March 2, 1877, upon his departure from Japan, Clark presented the "First Annual Report" to Kuroda. The report was filled with details about the Sapporo Agricultural College's progress, but also contained opinions on the purpose of the college, and the role of education in general. Clark wrote:

It has been well said "A country is nothing without men, men are nothing without mind, and mind is nothing without culture. It follows that cultivated mind is the most important product of a nation. The products of the farm, the shop, the mill, the mine, are of comparatively less value than the products of the schools. If the schools of a people are well taught, all else will prosper. Wherever schools are neglected it is a sure sign of national degradation and decay. The central point of every wisely administered government is its

165 Maki, William Smith Clark, Chapter VI, p. 16. 
system of education. The education of youth well cared for by a nation, out of it will grow science, wealth, strength, and all else that is esteemed great in the judgement of men." A profound respect for learning has long characterized the more cultivated nations of the East, but never has greater enthusiasm in the pursuit of useful knowledge and the establishment of educational institutions been manifested by any people than by the Japanese under the intelligent Government of His Majesty Mutsuhito. Actuated by this spirit, Your Excellency has founded the sapporo Agricultural college at the capital of your vast province of Hokkaido in order that the young men who are educated for officers may become familiar with its climate, soil, and resources, and be qualified to aid efficiently in the development of its various productive industries. ${ }^{166}$

The report not only shows that clark held education in high esteem, but that he understood its purpose in Hokkaido, and what goals needed to be set by the Japanese government for its effective implementation. Again, clark saw education as the very foundation of a nation, and applauded Japan's work to promote higher understanding among its people during the Meiji era.

CLARK IN THE FIELD AND CLASSROOM

In the classroom Clark displayed an interesting mixture of teaching techniques that no doubt contributed to his success as an educator. He required all students to keep English notebooks of their experiences at the college and provided detailed corrections and comments that contributed to the advancement of linguistic skills outside their regular 
language lessons. Clark emphasized the command of English and although he never learned Japanese, did not hesitate to stress the English portion of the entrance examination above all else. He brought with him from the United states several Webster Dictionaries, a rarity in Hokkaido, and freely distributed them among students for private use.

clark emphasized textbook assignments and often quizzed students on assignments given the day before. He made particular students, who had not been paying close enough attention, recite lengthy sections of the textbook in front of their peers.

As was mentioned, Clark's most popular contribution to education in Japan was his passion for field work. Because Sapporo was located in such an ideal location, surrounded by green hills and rugged mountains, it was perfect for observing and collecting botanical, zoological, and geological specimens. clark often took his students out to get a first hand look at the science he taught in the classroom. Oshima Masatake, a student of Clark's and member of the Sapporo Independent Christian Church, recalled:

He often led boys to the fields, forests and mountains. A strange procession of boys followed him, carrying guns upon their shoulders and large tin cans on their backs, with hammers and Jackknives hanging from their belts around their loins. Their excursion was to collect zoological, botanical and mineral specimens. President clark 
used to call such kind of activity christian work. ${ }^{167}$

This description captures the frontier intellectualism that clark so proudly exemplified. Clark's students, probably looking more like Canadian beaver trappers than the Kaitakushi's hope for the future, trekked into the wilderness hoping to find a better understanding of the world around them.

Probably the most celebrated account of clark's field research was a trip taken to Mount Teine, just outside Sapporo. As the story goes, while hiking through the wilderness searching for specimens to bring back to the college, clark, always on the look out for botanical wonders, spotted a lichen on a rock which was just out of reach. Osaka recalls the incident:

So, at once he was on all fours, in the snow, and called to the students, "get upon my back, anyone of you, to take that lichen." Not one of the students would do that for all the order of the 'regimental commander,' because they had been taught "being 3 feet apart behind your teacher, you shall not set your feet even on the shadow of him" in confucianism.

"Kuro!" he called to the tallest boy, Kuroiwa.

"Get upon my back. Take it."

Kuroiwa was going to take off his boots.

"No need. With your boots on."

Kuroiwa took the lichen reaching out his hand on the back of his teacher and handed it over to him. A storm of cheering arose from all sides. ${ }^{168}$

167 Oshima Masatake, "Reminiscences of Dr. W.S. Clark," The Japan Christian Intelligencer, (Vol. 1 No. 2, April 5, $1926)$, p. 58 .

168 Osaka, Kuraku sensei Shoden, p. 490-491. 
clark thought nothing of the incident and later sent the specimen to Amherst College where it was examined by Professor Frederick Tuckerman, who proclaimed it previously unidentified, and duly named it certraria clarkii.

clark began each morning with lessons from the Bible, which the students would memorize and recite to him. He met with students outside the classroom regularly, and could be often seen eating small mikan, or Japanese oranges, which, as he described to his son, he could purchase for "a cent apiece, and I buy them by the hundreds."169

On August 20,1876, clark wrote in a letter to his son that the Sapporo Agricultural College expected visitors from Tokyo. Clark wrote:

Tomorrow we expect some of the highest officers of the Imperial government to arrive here on a visit of inspection and pleasure. Great preparations have been made for their entertainment and $I$ suppose their will be more play than work here during their stay. ${ }^{170}$

clark mentioned nothing else of the visit in further communications with Amherst. Among the visitors, however, was Prime Minister Sanjo Sanetomi. He had traveled to Hakodate with the emperor on an inspection of Hokkaido and had come to Sapporo on Meiji's behalf. In a letter written to Director

169 William Smith Clark to Hubert S. Clark (My Beloved Boy), January 11, 1877, William S. Clark Collection, Archives and Manuscripts Department University Library, University of Massachusetts at Amherst.

270 William S. Clark to Hubert S. Clark (My Dear Boy), August $20,1876$. 
Zusho on August 25, 1876, the Prime Minister expressed his deep satisfaction with the progress of the institution.

I am happy to know that the students of Sapporo college are making progress under the exceptionally diligent instruction of President clark.

Upon my return to Tokyo, I shall report the particulars to the Mikado, and I doubt not His Majesty will be gratified.

Please communicate this to President Clark. ${ }^{172}$

The Sapporo Agricultural College, under the immediate observation of Kuroda, and the Direction of Zusho, and being created and cared for by clark, who gave the college, among other things, a sense of purpose, was off to a great start. The college immediately began to produce what the founders had anticipated -- vigorous individuals who through outstanding deeds and ambition contributed to the growth of Hokkaido and the betterment of Japan. From the first class emerged many outstanding men, including Sato shosuke, who fostered a life long connection with the college, and eventually taught there as an assistant to Professor Brooks. Although Clark did not know the members of the second class, they were also influenced by him, and possessed the spirit that he earnestly fostered in the hearts of his students. Such figures as Uchimura Kanzo ${ }^{172}(1861-1930)$, who became one of the most

171 Prime Minister Sanjo Sanetomi to Director Zusho Hirotake, August 25, 1876, William S. Clark Collection, Archives and Manuscripts Department University Library, University of Massachusetts at Amherst.

172 Born in Edo, Uchimura Kanzo was baptized in 1878 and later studied theology in the United States. After returning to Japan he was dismissed from First High School for 
important Christian leaders in Japan, and Miyabe Kingo, who became one of Japan's most famous botanists and later received a Doctorate from Harvard, came from the second class of the Sapporo Agricultural College. Nitobe Inazo ${ }^{173}$, graduated from the Sapporo Agricultural College and later signed the "Covenant of Believers in Jesus," which Clark and his first students created. The list of distinguished people goes on, and many will be discussed in more detail later, but it is enough to say that the principles upon which clark founded the Sapporo Agricultural College not only contributed to the success of the institution, but helped Japan emerge as a major cultural, economic, and military force.

criticizing the Imperial Rescript on Education. Officials believed that as a Christian Uchimura was incapable of feeling kokutai, a form of Japanese patriotism. Uchimura concentrated his efforts on writing and started his own journal the Tokyo Dokuritsu Zasshi, or "Tokyo Independent Journal." Because of his nondenominational approach Uchimura became the leader of the "no-church movement" in Japan and claimed to have allegiance to two "J's," Japan and Jesus. (Hunter, Concise Dictionary of Modern Japanese History, p. 236.)

173 Nitobe graduated from the Sapporo Agricultural College in 1881 and moved to the United States where he married and became a Quaker. After traveling in Germany he returned to sapporo and taught at the college. He taught at Kyoto University, the First High School, and Tokyo University. He was president of the Japan's Women's University and later worked for the League of Nations. He became a member of the Imperial Academy and joined the House of Peers in 1926. He was a strong critic of militarism and believed in international goodwill. He worked until his death trying to better international relations between nations. (Hunter, Concise Dictionary of Modern Japanese History, p. 150.) 
THE KAISHIKISHA, OR "ENLIGHTENMENT SOCIETY"

On November 1,1876 , a request to create a literary society at the Sapporo Agricultural College was drawn up by nineteen students and submitted to Director Zusho. The students explained the literary society was needed "in order to increase our knowledge and at the same time to improve our mode of speaking and writing both in English and in Japanese."174 Zusho promptly accepted the student's request agreeing that the organization would "increase and extend their understanding."175 The new organization was named the Kaishikisha, and the members met every saturday evening at seven o'clock. The members accepted a democratic constitution written by Clark (see Appendix E).

The original Kaishikisha was signed by over twenty-five students and its democratic nature and use of standardized parliamentary procedure are evidence of the early changes that were occurring in Hokkaido under the direction of clark. The Kaishikisha held over two hundred meetings and minutes were taken in English of all the proceedings. Even after Clark's departure the literary society proved successful, as one

174 "Your Obedient Pupils" to Director H. Zusho, November 1, 1876, william S. Clark Collection, Archives and Manuscripts Department University Library, University of Massachusetts at Amherst.

275 Director H. Zusho, Kaitakuno to President W.S. Clark, November 7, 1876, william S. Clark Collection, Archives and Manuscripts Department University Library, University of Massachusetts at Amherst. 
student wrote to Clark after his departure: "I am very happy to inform you that we have been successful in improving both our prayer meeting and literary society a great deal. Every one of the students in the college attends there."176

\section{THE BIBLE AND THE CLASSROOM}

More successful than the Kaishikisha was Clark's missionary work while in sapporo. It is unfair to clark and his students, however, to define clark's Christian activity as missionary and the term is only used for the sake of convenience. Clark did not enter Japan as a missionary, nor did he have any denominational affiliation. In fact, clark abhorred dogma, and his quality of christianity, which stressed spirit over words, was well received by his Japanese students. The ban on Christianity had been lifted in 1873, but this did not apply to Hokkaido and Christian teachings were still discouraged in the classroom and other public institutions.

Three major groups of christianity developed in the early Meiji era: the Kumamoto Band, the Yokohama Band, and the Sapporo Band. The Kumamoto Band was established in 1871 when Hosokawa Morihisa founded the Yogakko, or "School of Western Learning," to try and better the lot of his clan. The school

176 Torajiro Watase to President william Smith clark, December 2, 1877, William S. Clark Collection, Archives and Manuscripts Department University Library, University of Massachusetts at Amherst. 
was led by the son of a Congregationalist pastor, Captain Leroy L. Janes. At first, Janes simply taught at the school. Later, however, he introduced christianity and began regular Sunday services. By 1872, under Janes' tutelage, the Kumamoto Band had forty-two members. In the summer of 1876, however, because of strong opposition to Janes' teachings, the school was closed and the Kumamoto Band destroyed but for a few ardent believers who later worshipped at Niijima's Doshisha University. ${ }^{177}$

The Yokohama Band was started by Samuel R. Brown, James C. Hepburn, and James C. Ballagh. In 1872, under the leadership of Ballagh, the Yokohama Band was formally chartered and later developed into the protestant church of Japan. ${ }^{178}$ Clark and his students started the third group in Sapporo.

All three groups were nondenominational. "All three bands emphasized the teaching of the Bible as the basic doctrine of Christianity," wrote one author, "and ignored dogmatic complexities and denominational differences."179 It has been suggested that the reason nondenominational Christianity caught on among many young Japanese, specifically around universities that specialized in Western learning, was

177 Carlo Caldarola, Christianity: The Japanese Way ed. K. Ishiwaran (Alberta, Canada: University of Alberta Press, 1979), p. 27-28.

\author{
178 Ibid. \\ 179 Ibid., p. 29.
}


that it offered a replacement to Bushido, or the samurai ethos, that was being erased by the modernization process. This is correct in the case of clark, as he offered a new ethic to live by and the students, all young samurai, were enthusiastic about the new, imported ideas. clark only asked that they behave like young gentleman.

An example was when clark first arrived at the Preparatory School and was shown the rules and regulations of the institution. Clark was said to have laughed and explained: "These rules and regulations cannot make men: they should be abolished at once, and I will give only two words in their place, 'Be gentlemen.'"180

The moment Clark arrived in Sapporo he began his work proselytizing young Japanese eager for spiritual change. clark's missionary work was in the name of education and he firmly believed to his death that the only way to teach morality was to use the Bible as an example of what he referred to as "gentlemanly behavior."

Soon after clark arrived in Sapporo, he had a young Japanese student baptized in the honjin. Reverend Dening, an English missionary from Hakodate, first attempted to baptize the lad in his inn but was stopped by the inn keeper. He then tried to baptize the student on the street corner but a policeman interrupted the proceedings. He then approached Clark who let the ceremony proceed in his home. Clark wrote

180 Oshima, "Reminiscences of Dr. W.S. Clark," p. 56. 
to his brother William B. Churchill on August 5, 1876:

I have just had the first Japanese convert in Sapporo baptized in my house by Rev. Dening, an English missionary who has been preaching here a few days. He is a fine-looking youth from Tokyo who enters our first class and is said to be quite a painter of landscapes... His name is Ito [Kazutaka]. He expects ridicule from his fellows but says he can stand it. ${ }^{181}$

Clark's first attempt to use the Bible in classrooms at Sapporo Agricultural college was blocked by Kuroda, but he later slackened his position, and allowed clark to use the book for "high moral"182 education. After Kuroda gave his consent clark promptly distributed the Bibles he had received in Yokohama to his students and began to oversee their moral advancement. On November 28, 1876, clark had his students, many of whom were rowdy samurai from the southern provinces, signed a pledge of temperance. The pledge read:

The undersigned, officers and students of the Sapporo Agricultural College, hereby solemnly promise to abstain entirely from the use, in any form, except as medicines, of opium, tobacco and alcoholic liquors; and also from gambling and profane swearing, so long as we are connected with the institution. ${ }^{283}$

The pledge was signed by twenty-three students, nearly all the original class at the Sapporo Agricultural college. Osaka recalled the pledge, stating:

181 Maki, William Smith Clark, Chapter VII, p. 9.

182 Caldarola, Christianity: The Japanese Way, p. 28 .

183 Temperance Pledge, by william Smith Clark, November 28, 1876, William Smith Clark Collection, Archives and Manuscripts Department University Library, University of Massachusetts at Amherst. 
Clark brought much medical wine from America. But he thought, "As I am teaching them to abstain from wine and tobacco, I must cast away this wine myself first." Thus he made his servant break every bottle of wine, and drafted a temperance pledge, which not only the students signed, but he signed first himself. ${ }^{184}$

Osaka explained that the "pledge in Sapporo Agricultural College became one of the most important fountainheads of the temperance movement in Japan."185 Clark sent the pledge to Amherst where it, along with a lengthy article called "Temperance and Religion in Japan," appeared in the Amherst Record on February 7, 1877. With the pledge Clark also sent a letter written by one of his students explaining the nature of his faith. The letter is important to understanding the nature of Clark's proselyting:

I am also grateful for your kind gift of the Bible. I have read a few chapters of the New Testament, and although $I$ cannot understand the meaning clearly, yet I can apprehend the principle by careful study. So I am very much interested about it. Until a few days ago, I did not think about my future life. I thought, "when I die I shall become dust," but by reflecting upon it deeply, I found that there must be some place to go to. In order to go there, I must work very hard in this world, and at the same time I must be very good, kind and truthful man. And when I think about the universe, there must be some powerful being or God, as the Bible says, who made it. As He is the creator of all things, I must love $\mathrm{Him}$, so I pray to Him every morning and evening. As my idea is fixed in regard to this subject, I shall not change my mind unless some one will give me better information. ${ }^{186}$

184 Osaka, Kuraku sensei Shoden, p. 488.

185 Ibid., p. 488 .

186 Maki, william Smith Clark, Chapter VII, p. 12. 
On December 19,1876, clark received a letter signed by sixteen students which read: "We all desire to study the Bible. So we humbly ask your favor that you will teach us it on every Sunday hereafter." ${ }^{287}$ Clark accepted the student's request and started Sunday School at the Sapporo Agricultural College. Clark is reported to have even started every class session with the Lord's Prayer, but discontinued this practice "in order not to come to any collision with the government order. "188

Writing for the Japan Christian Intelligencer in 1926, Oshima gave a detailed look at Clark's Sunday school activity:

Let us give here a picture of the sunday school he taught fifty years ago. The method he used was quite original. The meeting was opened with the Lord's Prayer, which was followed by reading from the Bible. The passages were read by students in turn, and short explanations were given mostly for homiletic lessons. That was the regular part of the exercise. other things were extempore. Sometimes, he sat still for a few moments, and then burst out into a strong prayer, so impressive as to penetrate the heart of every one present. Sometimes, he read sermons, and essays from newspapers, journals, and books. Sometimes, he stood up and spoke with himself. He was naturally an eloquent speaker. His speech was always full of fire. When he spoke, it was so powerful that we felt, as if the whole building were shaken by his energy. Even dogs outside were frightened and barked and barked while he was preaching. At other times, he gave us gentle talks. Then, his delivery became sometimes dictative and sometimes persuasive, as a father talks to his children...

187 "Your Obedient Pupils, (signed by all students) to President William Smith Clark, December 19, 1876, Williams. clark Collection, Archives and Manuscripts Department University Library, University of Massachusetts at Amherst.

188 Oshima, "Reminiscences of Dr. W.S. Clark," p. 57. 
He made selections of good passages from the Bible, such as the one hundred-third psalm, the fifty-third and fifty-fifth chapters of Isaiah Beatitude, the thirteenth chapter of Romans and the thirteenth chapter of the first Corinthians, and let the boys commit them in memory and make rehearsals. Then, he let the boys select good pieces themselves. When our selections struck on good passages, and received high remarks, we felt very triumphant. Young folks always like to be praised. We searched and searched for good passages of the Bible, in order to get good high commendation of our master. . . ${ }^{189}$

Clark's unyielding ambition and sincere concern for moral education validated the spiritualism that he preached and made the students more eager to learn the foundations of "gentlemanliness." Oshima wrote:

Pres. Clark took great interest in the Bible, and paid great respect to it. When we called on him at night, we usually saw him with his spectacles on, almost absorbed in the reading of the Bible. Very often he told us, "This is the most wonderful book; every time I read it, I find some new truth in it." But he hated dogmas. When we asked him some difficult questions, he rebuked us at once. "Boys, you need not trouble yourselves with such unnecessary questions. When your ages mature, you will come to understand them. There are more important things to learn in this life from the Bible. Follow and practice them." Again, he said, "To be Christians, you must become upright, diligent students. Your calling is to improve the world and make it the kingdom of God. . ."

We approached christianity with our sense rather than with our heart. We saw it in the personality of Pres. Clark. We believed in the validity of the religion he professed, and made implicit obedience to him in his leading us to christ. We went to him one by one and made confessions to become followers of christ. ${ }^{190}$

189 Ibid., p. 57-58.
190 Ibid., p. 58-59. 
According to Oshima, Clark hoped to create a Church of Antioch in Sapporo, free from denominational quarreling, a place of worship founded on the idea of "freedom of faith."191 Oshima further explained:

It must have been his long hope to find new land, where people can worship God in spirit and truth according to the dictate of their own conscience. His hope was realized. He tried to test his ideal experiment upon the simple hearted young men of the new college and sow the seeds of gospel in the virgin soil of Hokkaido. ${ }^{192}$

In the words of Oshima, Clark stressed religious freedom, warning that denominational Christians "put greater stress upon the letter without than upon the spirit within."193 Oshima, expanding on Clark's instruction, explained:

The divisions of the sects are cutting up the bond of spiritual union which should exist among all the Christians of the world under the dispensation of one Lord, one faith and one baptism. Time is speedily coming when all such barriers will be taken away, or if not, they will be considered as a matter of minor importance. ${ }^{194}$

The matter of dogmatism was of such importance to Clark that after returning to Amherst he received a letter from Oshima requesting a Bible with explanatory remarks. "He sent me a large Family Bible full of marginal notes," wrote Oshima. "Upon its title page, he wrote with his bold hand: 'Your

$$
\begin{array}{ll}
{ }_{191} & \text { Ibid., p. } 59 . \\
192 & \text { Ibid., p. } 59-60 \\
{ }_{193} & \text { Ibid., p. } 60 \\
194 & \text { Ibid., p. } 61
\end{array}
$$


request is granted; do not become dogmatic.'"195 Clark intermixed his sunday school lessons with stories about the Civil War and other adventures that left "deep impressions upon the young mind far greater than the teaching of book morality did."296 Oshima explained that Clark's Christianity "was interesting to us because it was practical religion, unlike that taught by ordinary missionaries. It was religion without the odor of religion."197

"THE COVENANT OF BELIEVERS IN JESUS" AND THE DOKURITSU KYOKAI, OR "SAPPORO INDEPENDENT CHRISTIAN CHURCH"

On March 5, 1877, Clark wrote the "Covenant of Believers in Jesus." The Covenant was signed by thirty-one students, of which seventeen were members of the first class at the Sapporo Agricultural College. The document contained what may be regarded as Clark's version of the Ten Commandments, changed in order to accommodate his students (see Appendix F). The final paragraph of the document read:

For mutual assistance and encouragement we hereby constitute ourselves an association under the name "Believers in Jesus," and we promise faithfully to attend one or more meetings each week while living together for the reading of the Bible and other religious books or papers, for conference and for social prayer; and we sincerely desire the manifest presence in our hearts of the Holy spirit to quicken our love, to strengthen our faith, and to

\footnotetext{
195 Ibid., p. 59.

196 Ibid., p. 58 .

197 Maki, William Smith Clark, Chapter VII, p. 11.
} 
guide us into a saving knowledge of the truth. ${ }^{198}$

On March 5, 1877, Clark wrote his wife expressing his satisfaction with the Covenant and his missionary activities in general. clark was only a teacher, but any missionary in Japan would have boasted at having had the same success that he had in only eight months. Clark wrote:

The inducements to labor here are wonderful. Though there is not a minister within 150 miles and we dwell among heathen. Yet everyone of my college boys seems to be truly converted and living a most exemplary life. Today they have signed a paper which I prepared for them, which is the nearest I can come to organizing them into a church. I enclose a copy, which you can show Dr. Tyler and other friends, but let no one have. Who would have thought that I would have become a successful missionary! To God be all the glory. He can save by many or by few. ${ }^{199}$

Clark did not stay in Sapporo long enough to see his young disciples baptized. Six months after his departure, during the following september, members of the freshman and sophomore classes were formally baptized by M.C. Harris. ${ }^{200}$ About half of the original group abandoned their faith, but the members who continued in 1882 established the Dokuritsu Kyokai, or "Sapporo Independent Christian Church." Among the founders were Uchimura Kanzo and Nitobe Inazo. The Sapporo church remained independent from denominational control and the influence of missionaries. According to the Hokkaido

\footnotetext{
198 Maki, William Smith Clark, Chapter VII, p. 14-15.

199 Maki, William Smith Clark, Chapter VII, p. 13.

200 Osaka, Kuraku sensei Shoden, p. 492.
} 
prefectural government, the covenant remains "one of the important documents of Christian history in Japan."201 Maki concluded that clark's success as a missionary "was due to the fact that he was not one."202

A product of the "Sapporo Independent Christian Church" was the Non-Church Movement whose founder was Uchimura. After graduating from the Sapporo Agricultural College, Uchimura went to the United States to study theology. In 1885 he studied Greek and Hebrew at Amherst College and later, in 1887, at the Hartford Theological Seminary. Uchimura's experience in the United States, however, was plagued by many "unchristian features of Christiandom,"203 which included racial discrimination while on the west coast. As a result, Uchimura began to seriously question the foundations of his missionary education, and decided that no church, no centralized dogma, as clark had taught, was best. Subsequently, Uchimura returned to Japan and spearheaded the Non-Church Movement believing that Japan and Jesus were his highest devotions.

Clark's teachings also survived in the minds of others. After Clark returned to Amherst his disciples continued to write. The letters are evidence of the lasting impact that

201 Hokkaido Prefectural Government, Foreign Pioneers, p. 80.

202 Maki, William Smith Clark, Chapter VII, p. 16. 203 Caldarola, Christianity: The Japanese Way, p. 44. 
Clark's Christian moralizing had upon his students. On November 23, 1877, Arakawa Shigehide wrote that it had been several months since Clark was last in sapporo doing the "greatest and most important services both to the Lord and to the Empire, by converting us, students of Sapporo Agricultural College who were dark heathens,"204 and that the students of Sapporo missed his presence. Arakawa continued: "We are now a firm and strong Christian army and are attempting to increase the kingdom of Him in the Heathen Island. Though we are encompassed on all sides by the heathens, our dreadful enemies, we can go everywhere without fear of them, believing steadfast that the Lord is always with us."205

On December 2, 1877, Watase Torajiro wrote that he had "been born again on the 1st of sept. and I thank you that this new life I could obtain was simply owing to your kind teaching." Reo Referring to Clark's christian teaching, Watase continued:

It is my sincere hope that I may hereafter convince you that the seed you have sown in my heart in not altogether a worthless one, but that which will produce good yield. I have indebted a great deal of gratitude to you which I think I can pay of no other method but by causing my neighbors to accept

\footnotetext{
Arakawa Shigehide to William Smith Clark, November 23, 1877, William S. Clark Collection, Archives and Manuscripts Department University Library, University of Massachusetts at Amherst.

205 Ibid.

206 Watase Torajiro to William Smith Clark, December 2,
} 
the holy doctrine of Jesus Christ. ${ }^{207}$

On December 5, 1877, Ono Kauemoto wrote to Clark explaining it was the first lesson that clark ever taught the students in relation to christianity that had had the most impact on his thinking. Ono wrote:

The first lesson which you taught us is the existence of the Almighty God but as we were grown in the midst of the heathen idolaters, I have believed your instruction but my head is sometimes disturbed by doubt. When you have taught us the lessons in Human Anatomy and Physiology, I was shocked and astonished by the ingenuity as well as the benevolence of the Maker. ${ }^{208}$

On August 6, 1878, Clark wrote to Niijima at Doshisha explaining the state of his accomplishments in Sapporo, and added that the Kaitakushi, which had originally opposed the missionary work, still did not interfere. clark wrote:

I was very sorry to learn by your letter of April 29th that you were out of health, and also that you had met with some unusual trouble in your School. of course you must expect some difficulties in carrying on so great and novel a work, and it would indeed be wonderful if your body were never worn out by your many labors. I hope however your anticipations of prosperity have ere this been fully realized and that the glorious work of the Lord is prospering in your hands as never before.

I am happy to inform you that my students in Sapporo continue steadfast in the faith and are very earnest and successful Christians. Rev. M.C. Harris of Hakodate had recently baptized seven

207 Ibid.

208 Ono Kauemoto to President william Smith clark, December 5, 1877, William S. Clark Collection, Archives and Manuscripts Department University Library, University of Massachusetts at Amherst. 
freshman, and the Kaitakushi does not interfere. ${ }^{209}$

Clark's missionary work had a lasting impact in Sapporo. In 1914 ten of the students who originally signed the "Covenant" mounted a campaign to raise funds to erect a church in honor of Clark. The proposed name was "The william s. Clark Memorial Church," and they characterized the church in the tradition of "independent, non-sectarian, democratic and Biblical,"210 values. Eventually they raised 60,000 yen and in 1922 the memorial church was opened to the public. The location of the church was its downfall, however, as real estate prices rose, the land that the church was built on went up in value and the church was eventually razed and relocated. In the new church is the original "Covenant of the Believers in Jesus," and several of the Bibles that clark brought up from Yokohama. Maki explained: "All these are regarded with a veneration just short of that usually reserved for saintly relics in the Western world."211

Osaka explained that Clark's "service in the religious world of Japan was the greatest among all contributions made by him."212 Oshima wrote, referring to the lasting effect

209 William Smith Clark to Reverend J. Neeshima, August 6, 1878, William S. Clark Collection, Archives and Manuscripts Department University Library, University of Massachusetts at Amherst.

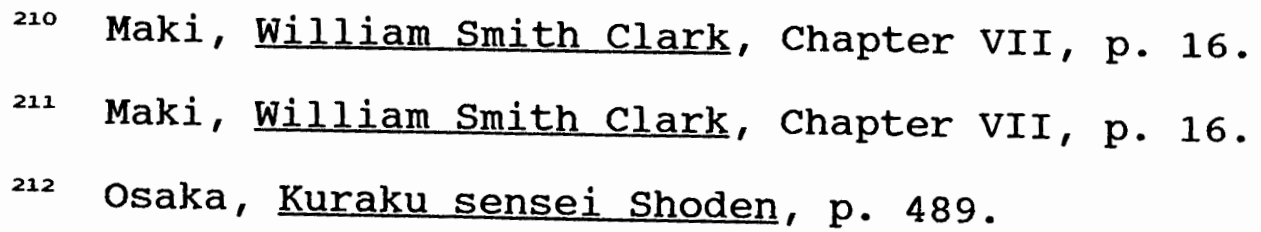


that clark had on his students both spiritually and practically, that his students had infiltrated all facets of Japanese life and thus the wisdom of Clark was spreading:

He led myself and my classmates to christ. We feel ever thankful to him, and will never forget his name, as long as we live under the abundant blessings of Him to whom he led us. His disciples and their followers have been spreading his influence throughout the whole empire, some serving in the government and business companies, some engaging in educational work, and others carrying on their independent enterprises. They are all intelligent, upright men, and are contributing their important work to their country. If General Kuroda had lived long enough to see the kind of men, whom he had wanted and whom President clark had reared, he would have been greatly satisfied. ${ }^{213}$

\section{CONCLUSION}

Through the creation of a liberal arts curriculum at the Sapporo Agricultural College, the founding of the Kaishikisha and the "Covenant of Believers in Jesus," and a sincere belief in the power of values in education, clark introduced to Hokkaido an educational system beyond the vocational program that originally interested the Kaitakushi. Clark's beliefs, as did his creations, became a model for the development of student behavior at the Sapporo Agricultural College. Clark's Christian leadership was such a profound model that his students later became the spokesmen for Christianity in Meiji Japan and the leaders of liberal reform and internationalism for future generations. 


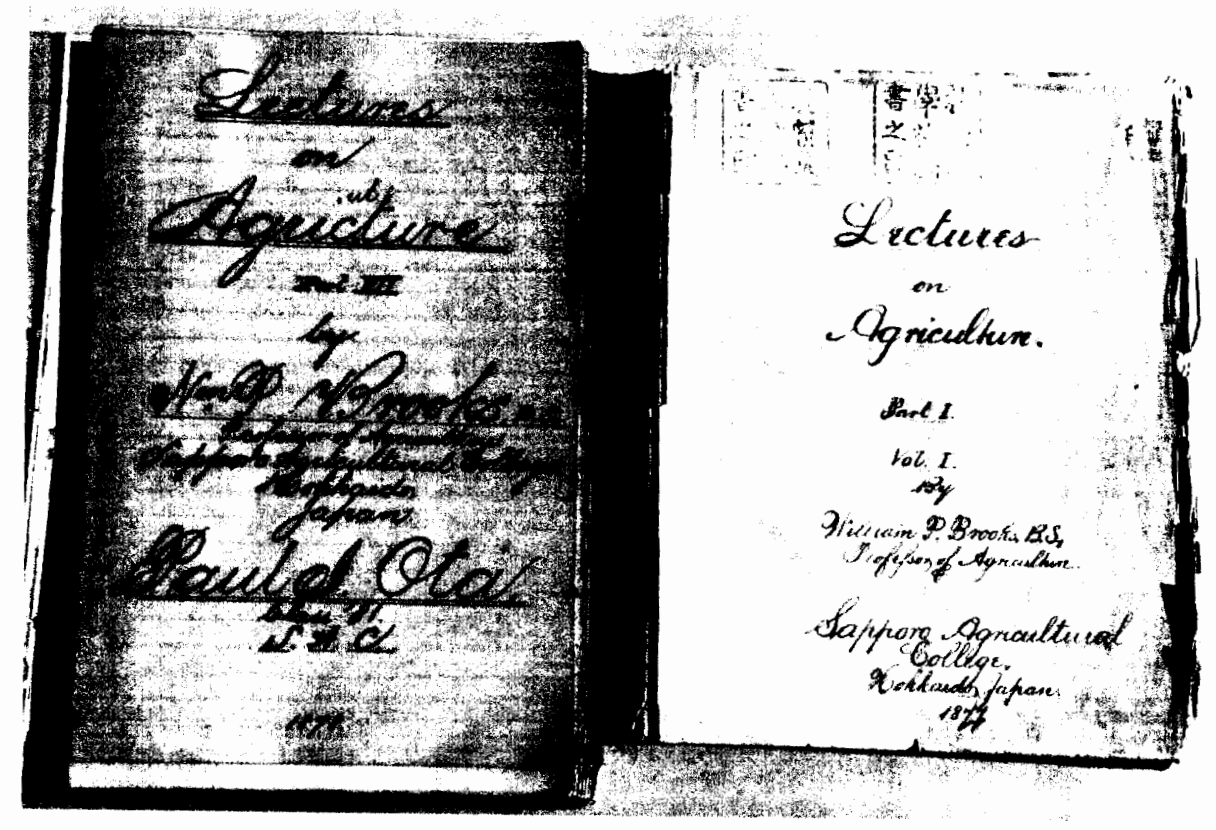

Figure 7. Nitobe Inazo's (Christian name: Paul ota) notebook while studying at the Sapporo Agricultural College. (William Smith Clark Collection, Archives and Manuscripts Department University Library, Hokkaido University.) 


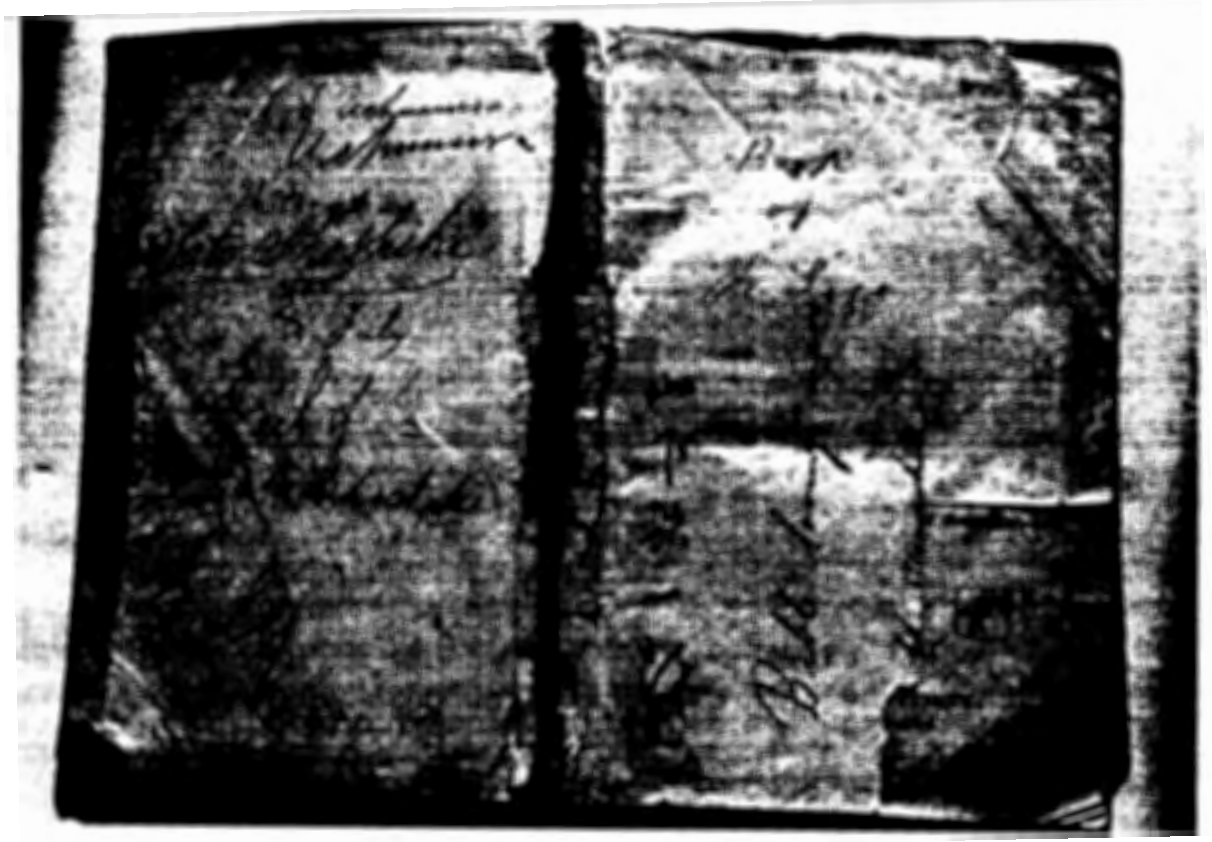

Figure 8. Uchimura Kanzo's Bible while studying at the Sapporo Agricultural College, and member of the Sapporo Independent Christian Church. (William Smith Clark Collection, Archives and Manuscripts Department University Library, Hokkaido University.) 
CLARK'S LEGACY AND CONTRIBUTION TO THE MEIJI RESTORATION

After Clark departed from Hokkaido, the Sapporo Agricultural College continued to prosper. Even students who attended the school after clark had left for the United states referred to themselves as products of his teaching. Before Clark left Japan he inspected experimental farm sites for the Kaitakushi, secured certain teaching and administration positions at the college, wrote the Final Report for the Meiji government, and spoke the enduring phrase: "Boys, be ambitious."

After his departure, the Sapporo Agricultural College grew and became the Imperial University of Hokkaido, then later, after World War Two, Hokkaido University. The college still celebrates clark as the founder, and graduates of the college identify their education with clark's pioneer spirit and ambition. It is in the minds of these students that clark's accomplishments should be measured.

CLARK'S DEPARTURE FROM THE SAPPORO AGRICULTURAL COLLEGE

On March 13, 1877, clark submitted to Director Zusho a plan for the 1877-1878 academic year at the sapporo Agricultural College. Clark requested that Professor wheeler 
be made acting president upon his departure, that three new Japanese instructors be employed by the Kaitakushi, that the affairs of the experimental farm be placed in the hands of Professor Brooks upon his arrival, and that Yoshida Kiyonari be recalled from the United States to assist in the management of the experimental farm. On March 22, 1877, Clark submitted a second memorandum to acting Governor Hori requesting that a shed be constructed adjoining the existing barn that clark had overseen earlier. Kuroda was in Kyushu, leading imperial forces against the Satsuma Rebellion. ${ }^{214}$ He submitted a list of books and materials that he believed essential for the maintenance of the college and volunteered to purchase and send the books once in the United States. Clark's final days in Sapporo were marked by a succession of requests and accomplishments that he believed necessary for the survival of the college after his departure.

On March 5, 1877, Clark wrote to his wife: "The Lt. Governor requested me to renew the contract for three more

214 The Satsuma Rebellion in 1877 was the biggest antigovernment uprising in the Meiji years. It was led by Saigo Takamori and conservative samurai because of discontent over certain reforms and foreign policy in Korea. The rebellion started in January, 1877, when Saigo led 13,000 followers towards Tokyo but was delayed by the imperial garrison at Kumamoto. Saigo was forced to retreat to Kagoshima where he took his life in september, 1877. The military engagement is important because the imperial army was made up of common soldiers, not samurai, and they were equipped with modern weaponry. It marks the end of the samurai and the superiority of the traditional warrior ethos. Kuroda commanded imperial troops during the conflict. 
years, with permission the visit you next summer,"215 but the possibility of a renewed contract was never again mentioned by clark. Wheeler, in letters written to his mother, suggested that clark "seems to consider it quite possible that he may return for three years more," ${ }^{216}$ but on April 17, 1877, Wheeler, under Clark's previous recommendation, was made president of the Sapporo Agricultural College. Clark's contract was not renewed by the Kaitakushi. According to Osaka, Clark wrote to his wife, in a letter that is no longer available, that he preferred to return to Amherst and spend time with his family and continue his presidency of the Massachusetts Agricultural college. He believed his work was completed in Hokkaido and that if the college was left in capable hands it would survive and prosper. Clark had already provided the Sapporo Agricultural College with a purpose, now it only needed to carry out these goals.

On April 10, 1877, Director Zusho wrote to Clark:

Your homeward departure being close at hand, allow me to express a few words for a small token of our parting wishes. Indeed it is by the good cultivation of mind alone that we can hope for the plentiful harvest of the wealth and prosperity of a nation.

Your engagement with our Empire as the President of the Sapporo Agricultural College and the Director of the college farm is distinguished, in spite of its shortness, by the great success in every course of your duty including the improvement of the farm and the erection of the barn for the general imitation of the whole Empire, the

215 Maki, William Smith Clark, Chapter VII, p. 27.

216 Ibid., Chapter VII, p. 28. 
establishment of the perfect rules for the faculty and students to act accordingly and above all the sowing of that splendid seed of both moral and mental enlightenment which characterizes every trait of Massachusetts. It will be our utmost and everlasting pleasure to see that it springs up and brings forth fruits in not very distant days, for which we owe our gratitude to you the first and most successful president of the sapporo Agricultural College.

with sincere wishes for your pleasant voyage and hoping that our expectations for your early return to Japan again will be realized I have the honor to remain, sir, your most obedient servant, Hirotake Zusho. ${ }^{217}$

Zusho believed that education was the foundation of a nation and that clark had contributed to the development of the empire. Zusho submitted that enlightenment must be accompanied by moral growth, and that clark, by planting the "seed of both moral and mental enlightenment," had made an immeasurable contribution to the advancement of Hokkaido, and in a larger sense, to Japan. On April 14, 1877, Clark wrote to Zusho:

In retiring from the service of the Japanese government I find it to be impossible to refrain from expressing my most hearty thanks to yourself and all other officers with whom $I$ have had business intercourse for the uniform courtesy and confidence with which I have been treated. This treatment has been of great advantage both to myself and to Japan, since it has enabled me to accomplish my mission in a manner satisfactory to the Kaitakushi and most agreeable to myself. I can truly say I have enjoyed my work here very much and I earnestly hope for valuable results in the years to come.

If the education of the cadets at the college

217 Director Zusho to President William Smith Clark, April 10, 1877, William Smith clark Collection, Archives and Manuscripts Department University Library, University of Massachusetts at Amherst. 
can be carried on with the liberal spirit which had characterized its management the past year I am confident the graduates will not disappoint the great expectations of its founders. They will be men distinguished for their integrity, earnestness and practical knowledge, such as are required for the important enterprise of the Department in developing the resources of Hokkaido. In selecting officers for the college and preparatory school I trust the utmost care will always be taken to employ men of perfectly unexceptional moral character as well as scholarly attainments. In obtaining a second president and teachers for the next collegiate year time enough should be allowed for their selection and journey that there be no failure.

In conclusion, I beg to thank you for the very complimentary testimonial with which you have been pleased to honor me. Both I and my children will preserve it with constant care as among the most precious of our possessions, believing with Solomon that "A good name is rather to be chosen that great riches."

With best wishes for your highest prosperity in the enjoyment of a long and happy Iife, I have the honor to remain, Your Excellency's most obliged and most obedient servant, W.S. Clark. ${ }^{218}$

Before his departure from Sapporo, Clark agreed to make several stops on the way to Amherst to collect information for the Kaitakushi. Clark agreed that upon his departure he would stop at the experimental farm in Nanae, near Hakodate, and report on the progress of the farm and the soil conditions there. Clark also agreed to travel to Muroran to investigate the possibilities of a major road connecting that city with Sapporo, and the creation of another experimental farm. Once in the United States, clark agreed to travel to Astoria,

218 William Smith Clark to Kaitaku Gon Daishiokikuwan, Zusho Hirotake, April 14, 1877, william Smith Clark Collection, Archives and Manuscripts Department University Library, University of Massachusetts at Amherst. 
Oregon, to observe and write on the salmon harvest then send a detailed report back to the Kaitakushi, which was interested in developing the salmon runs of Hokkaido. Capron and Clark had both discussed the possibility with Kuroda of developing the salmon canning industry, and from the nature of the request, the Kaitakushi had decided to pursue the suggestion. On April 16, 1877, eight months after his arrival, Clark prepared to leave the Sapporo Agricultural College. Classes were suspended for the day and the students and officers all assembled in front of the honjin for a group photograph. The group then travelled east to the village of Shimamatsu and ate lunch at the home of Kiuzo Nakayama, "famous since 1881 as a place of the Emperors sojourn."219 Following lunch clark and his students went on one final browse through the hills and forests surrounding Shimamatsu. It was their final field trip with clark.

There are two accounts of clark's departure, both written by Oshima. In 1926 Oshima wrote:

We escorted him on horse backabout five miles. We dismounted and rested for a while. The anticipated time of parting came at last. He stepped forward and shook hands with every one of us. All of us could not look up. We felt as if we were being bereaved of our dear old father. When we were parting, it certainly gave us inward pain. He mounted again on horse back and taking reign in one hand, and a whip in the other looked back towards us, and called aloud: "Boys be ambitious like this old man." He gave one whip to his horse, and straightly went off. No more, President clark! 
We never met him again. ${ }^{220}$

Ten years later Oshima wrote a slightly different account of the parting which has become the standard telling of the nearly mythical departure. It contains the phrase: "Boys be ambitious." Oshima wrote:

The students sat around the Professor, and full sorrow of parting, were absorbed in their last talk with him. Their teacher looked wistfully into their faces and shook hands firmly with each, and said these words in an emphatic tone, "Please write to me once in a while; even a single card will do. Now I must say good bye. I hope you will be well and strong and not forget to pray always." The moment he sprang on his horse, he exclaimed, "Boys, be ambitious," and swinging a long whip and turning around again and again, he went away along the slushy road and was lost behind a thin wood. ${ }^{221}$

Although the two versions are slightly different, the basic feel for the departure is the same. clark combined the scientific necessity for the success of the Kaitakushi, but also instilled in his students and colleagues the understanding that practical learning must be accompanied by ethical training.

Clark was in Japan to create educated men who through example and industry could lead their country to a better day. Nitobe wrote of the impact that clark had on his students:

He left behind him a memory not easily to be effaced. That manly spirit he instilled into his young students at the age when they were most susceptible of external influences, was not to be easily forgotten. Of lasting benefit to those, who came into close personal contact with him, was that

220 Oshima, "Reminiscence of Dr. W.S. Clark," p. 59.

221 Maki, William Smith Clark, Chapter VII, p. 33. 
invincible energy, which was his -- and without which, it is said, neither circumstances nor talents can ever make of a two-legged creature a $\operatorname{man} .222$

Clark must have reflected while riding his horse through the thinly wooded areas of eastern Hokkaido, that his mission in Sapporo, although short, had been successful. He left behind an agricultural college, a literary society, an independent christian church, models of architecture and methods of farming, and a brood of young minds possessed with the spirit of learning and contribution. These people shaped the future of Hokkaido. He also left behind Japanese colleagues like Naito, Kuroda, Zusho, and Hori who shared the same ideals and believed that clark had planted the seed of enlightenment in the rich soil of Hokkaido, and that Japan's future depended on the care that the seedling was shown.

\section{INSPECTION OF THE EXPERIMENTAL FARM AT NANAE AND IZARI, AND THE ROAD BETWEEN SAPPORO AND MURORAN}

After leaving Shimamatsu Clark travelled towards Nanae. His former student Yuchi sadamoto was director of the experimental farm, and Clark was to check his progress. En route to Nanae, Clark stopped at Izari to take soil samples as directed by the Kaitakushi. Clark wrote that Izari "seems to

222 Nitobe Inazo, The Imperial Agricultural College, p. 
be a very suitable location for a stock farm," 223 the open land being good pasture. Clark then stopped at Muroran were he was "sorry to find the soil. . . poorly adaptable to profitable farming without which no prosperous settlements can be established."224 Because of the poor quality of land, Clark suspected that the "grand highway from sapporo to Hakodate will never be of much value for the development of Hokkaido."225 Clark believed that resources and goods could not be transported "across the plain of volcanic ashes to the harbor at Muroran."226 He recommended that the harbor at Otaru be renovated to accommodate transportation of large quantities of goods to sapporo. Clark wrote that everything was proceeding well at Nanae but recommended that Yuchi be sent "a few bushels of the Massachusetts corn for seed. The latter has a large amount of land to plant and his seed is of poor quality." 227

On April 25, 1877, Clark left Hakodate for Nagasaki. He planned to travel through the Kansai area from Nagasaki to Tokyo. On June 5, 1877, Clark sailed "in a fine American-

${ }^{223}$ William Smith Clark to Honorable H. Zusho, April 22, 1877, William S. Clark Collection, Archives and Manuscripts Department University Library, University of Massachusetts at Amherst.

$\begin{array}{ll}224 & \text { Ibid. } \\ 225 & \text { Ibid. } \\ 226 & \text { Ibid. } \\ 227 & \text { Ibid. }\end{array}$


built steamer through the charming scenery of the Inland Sea," 228 and docked at Kobe. Clark dined with Dr. L.H. Gulick who was impressed with Clark's missionary accomplishments while in Sapporo. Clark wrote to his wife on June $5,1877:$

At Kobe I had the happiness of dining with the venerable Father Gulick and his wife who resides there with her three missionary children, and though more than eighty years old enjoy comfortable health. - Dr. L.H. Gulick agent of the American Bible society for China and Japan resides in Yokohama, but happened to be in Kobe while I was there. I reported to him in regard to the thirty Bibles he gave me to use while in Sapporo. He was amazed and delighted, and gave me thirty more, which I forwarded to Prof. Wheeler for the next class. . . 229

clark then travelled to Osaka where he "took tea with J.H. Deforest," 230 whose daughter was a former student of Clark's sister, Isabelle. He then travelled to Kyoto to visit Niijima. Clark commended Niijima for his work and committed himself to find books for his struggling Christian University. Clark sailed from Kobe to Yokohama on May 17, 1877, and "was soon reinstated in my last summer's house at Yokohama."231

228 William Smith Clark to Mrs. Harriet Clark, May 2, 1877, William S. Clark Collection, Archives and Manuscripts Department University Library, University of Massachusetts at Amherst.

229 William Smith Clark to Mrs. Harriet Clark, June 5, 1877, William S. Clark Collection, Archives and Manuscripts Department University Library, University of Massachusetts at Amherst.

230 Ibid.
231 Ibid.


While in Yokohama, clark read proofs from the "First Annual Report of the Sapporo Agricultural College" and had copies sent to such distinguished friends as Bingham, the American Minister to Japan, Mori Arinori, Dr. James Hepburn, originator of the Hepburn system for the Romanization of the Japanese language, and Minister of Education Tanaka. On May 24, 1877, Clark left Yokohama for Tokyo where he attended a farewell gathering. Kuroda had taken leave from the fighting in Kyushu to say farewell to his friend. Clark described the party to his wife:

At Tokyo I was treated as usual, every acquaintance striving to do something for me. On one day I had five invitations to dine with distinguished personages, but remembering that I was mortal, I accepted only one. This was at the Imperial gardens. Gen. Kuroda was the host and among the invited guests were acting Prime Minister Iwakura, Minister of Foreign Affairs Terashima... Vice Minister of Education Tanaka, etc. etc. It seemed to be a pleasant occasion! I dined also at Dr. Murray's with Mr. and Mrs. Tanaka and several professors of the University of Tokyo. . . . ${ }^{232}$

On March 5, 1877, Kuroda expressed his personal gratitude to clark for all he had done while in Hokkaido. Kuroda wrote:

As agriculture is the principal element for opening up and settling a country, it was the wish of this Department to establish an institution where students should be taught in that useful branch of Science, in order to enable them in the future to undertake the task of developing the islands of Hokkaido. In this object you were warmly invited from abroad and entrusted with the organization and management of the sapporo Agricultural college and its experimental farm.

It is now scarcely a year since you entered upon that responsible duty, but by your zealous 
efforts and hard work, not only has the system of the college been properly established but also the students have already made considerable progress. Indeed it would have been impossible to effect such a speedy success, had its organization and system of instruction not been well planned.

Now you are leaving this country; but there is hardly a doubt that, by following the course of education you marked out, and with the help of the good instruction to be given by the three professors you leave behind, many useful men will in the future come out from that college and assist the work of the Department so as to accomplish our desired object.

I am happy, on the termination of your term of engagement, to express our entire satisfaction with the work done by you. . .. ${ }^{233}$

Kuroda, on behalf of the imperial government, presented clark with two vases as a token of gratitude. On May 22, 1877, Clark wrote the following response:

Please accept most hearty thanks for the superb presents of bronze and lacquer received from Your Excellency yesterday. The accompanying letters were even more acceptable than the magnificent gift. There can be no higher reward for the faithful service than "the entire satisfaction of those whom we serve." I return to America with increased admiration for Japan and the Japanese.

With the profoundest gratitude to your Excellency for your confidence and kindness, and with high expectations for the future of Hokkaido, I remain, with great respect, Your Excellency's most grateful and most obedient servant, W.S. Clark. ${ }^{234}$

Before clark departed from Tokyo, the Kaitakushi

${ }^{233}$ Kuroda Kiyotaka, Kaitaku Chokuwan to President william Smith Clark, May 21, 1877, william S. Clark Collection, Archives and Manuscripts Department University Library, University of Massachusetts at Amherst.

234 William Smith Clark to His Excellency, General K. Kuroda, May 22, 1877, William S. Clark Collection, Archives and Manuscripts Department University Library, University of Massachusetts at Amherst. 
requested that he obtain and send information about breeding, canning, and preserving oysters. This information could be obtained while Clark was in Astoria so Kuroda approved Clark's request for two hundred and fifty gold yen as travel expenses to Astoria to visit the operations.

After visiting Astoria and writing on the salmon industry, Clark was met by his son Atherton in San Francisco. They arrived together in Amherst on July 28, 1877. While in Massachusetts clark maintained contact with many of his Japanese friends and received many complimentary letters. These letters are testimony that the Sapporo Agricultural College was blossoming into the center for advancement in Hokkaido that he had hoped for. Governor Hori wrote clark on March 25, 1878: "It is my pleasure to tell you that the college and the college farm are doing very well and prove to be a great source of intellect and intelligence for this good Hokkaido of our empire."235 Governor Hori explained, in a second letter, that the college and the college farm were "rapidly progressing in their way of important destinations which is nothing but the result of your considerate and well directed efforts."236

235 Vice Governor Hori Motoii to William Smith Clark, March 25, 1877, William S. Clark Collection, Archives and Manuscripts Department University Library, University of Massachusetts at Amherst.

236 Vice Governor Hori and $H$. Sato to William Smith Clark, March 25, 1877, William S. Clark Collection, Archives and Manuscripts Department University Library, University of Massachusetts at Amherst. 
The most interesting letter that clark received while in Massachusetts was on January 14, 1878, from the Legation of Japan. Head of the Legation Yoshida Kiyonari wrote:

We want your help, and I write to ask you for it, in a matter connected with the Revision of our Treaties with the Foreign Powers. It has occurred to me that if you were to deliver a Lecture in Boston, you could do the cause much good. You might start out with the idea of giving some recollections of Japan, and then discuss the treaty business. If you will consent to deliver such a lecture, I will at once post you with facts and figures, so that you would not have much trouble. They are now moving "all along the line" and Japan, not England, "expects every man to do his duty."237

Yoshida then went on to describe the injustices that had been inflicted upon Japan by foreign powers. Referring to the Tariff Convention of 1866, which fixed a five percent customs duty on Japanese imports and exports, Yoshida explained that as long as this system was intact, "Japan must of necessity suffer annual loss in balance of trade -- thus preventing her noble endeavors in the march of progress and civilization."238 The document sheds light on many of the grievances felt by the Japanese towards the foreign powers, specifically England, and is thus provided (see Appendix G).

The Japanese government obviously put pressure on the Legation and Yoshida, knowing that Clark was a skilled and respected scholar, not to mention a moving orator, petitioned

237 The Legation of Japan in Washington to Professor Clark, January 14,1878 , William S. Clark Collection, Archives and Manuscripts Department University Library, University of Massachusetts at Amherst.

238 Ibid. 
Clark to speak on behalf of the imperial government. Clark wrote back, and sympathized with the Japanese case, but never went so far as to lecture on the topic. Clark was involved with a business scandal in Massachusetts, and although vindicated, his name lost much of the respect it had commanded before.

Clark was a friend of the Japanese but was powerless on such affairs as international disputes. On october 15, 1879 , Clark wrote to Kuroda:

The recollections of my life in Dai Nippon are among the most precious treasures of my memory, and I can never forget the confidence and courtesy with which I was treated by all with whom I came into contact and most all by Your Excellency. I shall always rejoice in the prosperity of your Empire and particularly in that of Hokkaido, and shall always be glad of opportunities to serve my Japanese friends. ${ }^{239}$

THE SURVIVAL OF THE SAPPORO AGRICULTURAL COLLEGE: TESTIMONY TO CLARK'S LEGACY

clark was only able to personally shape the destiny of the Sapporo Agricultural College for eight months, but the strong sense of academic purpose that he instilled in the college provided it with the strength needed to overcome initial obstacles that the college faced, and to develop into a nerve center for not only the development of Hokkaido, but for Japan as a whole.

239 William Smith Clark to His Excellency, General $\mathrm{K}$. Kuroda, Kaitaku Chokuwan, October 15, 1879, William S. Clark Collection, Archives and Manuscripts Department University Library, University of Massachusetts at Amherst. 
Years after his graduation from the Sapporo Agricultural College, Nitobe wrote a sketch of the progress of the institution immediately following Clark's departure. Although information is somewhat scarce, from Nitobe's account the general success and strength of the college is visible. Also fascinating is Nitobe's version of the mission of the Sapporo Agricultural College. Far from just an institution to provide the technical training necessary to settle Hokkaido, Nitobe describes the college as in the German tradition of "cameralistic science."

After Clark's departure, wheeler became president of the college. Wheeler, besides serving as president, also rendered the Kaitakushi valuable service in surveying and engineering and built a weather station on Mount Teine. Penhallow also stayed behind continuing his duties as an instructor. Outside the contributions he made in the classroom, Penhallow served the Kaitakushi by advising on the tanning of animals and on textile fabrics that could be produced in Hokkaido.

During the academic year of 1877-1878, under the presidency of wheeler, a chemical laboratory was completed on the Sapporo Agricultural College campus, along with a greenhouse used for agricultural and botanical purposes. Many of Clark's students who had enjoyed collecting started a museum of Natural History. Thus significant improvements were 
made to the college immediately after Clark's departure. ${ }^{240}$ The academic year of 1878-1879 also saw improvements. The college opened with a capacity fifty students after establishing a reputation as a liberal institution. During this year the Military Hall was completed after the plans had been drawn up by wheeler sometime before. This building, now one of the most important symbols of Hokkaido, was opened in October, 1878, and was to be used for lectures, an armory, and a drill hall for the Hokkaido militia and the students at the Sapporo Agricultural College. Known as the Daitoke, or "clock tower," it still stands in Sapporo and is one of the most affectionate pieces of Hokkaido's history.

This year also saw the acquisition of valuable equipment and faculty. Important additions to the library were made while the newly build chemical laboratory was outfitted with instruments and chemicals. John C. Cutter became professor of Physiology and Comparative Anatomy, Cecil H. Peadbody became professor of Mathematics and Mechanics, Lieutenant Kato became Military instructor, and Michimasa Miyazaki became assistant to the chemical laboratory. Upon the acquisition of these valuable faculty and equipment, wheeler reportedly said: "The institution has passed the formative stage, and is now possessed of all the important requisites for its legitimate 11.

240 Nitobe Inazo, The Imperial Agricultural College, $p$. 
work." 241 Some minor changes were made in the curriculum, but generally speaking, the formula laid down by Clark was kept intact.

The college also published the Sapporo Nogakko HokokuSho, a monthly college bulletin edited and published by students at Sapporo Agricultural college. The college journal was a way for the college to relay valuable information concerning agriculture to the farming community. Also, in October, 1878, the Sapporo Agricultural College held its first college fair under the direction of Brooks, who was caretaker of the experimental farm.

During the academic year of 1879-1880 some of the basic curriculum developed by clark was eliminated and replaced. Clark's Mental and Moral Health class was dropped for the more traditional Philosophy of History which included the Political History of Europe. Reforms were also made in the number of students who could attend the college.

In 1880 , the first class graduated. The class had started with twenty-four students but by the time of graduation was thirteen. They were given the degree of nogakushi, or "Bachelor of Agricultural Science," and found jobs waiting for them in the Kaitakushi. Penhallow and Brooks both served as president of the college until the position was abolished in 1886. The Director then became acting college president.

24 Ibid., p. 12 . 
The first major crisis to face the college was the abolition of the Kaitakushi in February, 1882. The college survived, however, and was placed under the control of the Department of Agriculture and Commerce. Later, in 1883, the college was placed under the control of a subcommittee called the Kanri-Kyoku, or "Bureau of Supervision." In 1886 further reforms were instigated on the island of Hokkaido. Until this time, Hokkaido had been divided into three Ken, or "prefectures." After 1886 the whole island was put under one administration called the Hokkaido-cho. The college was placed under the joint authority of the governor of Hokkaido and the Department of Public Instruction.

In March, 1887, Shosuke Sato was made director of the Sapporo Agricultural College. He was a student of Clark's and had studied in the United States at Johns Hopkins University. Under the leadership of Sato, the college offered two degrees where it had only offered one before. The college now gave both the nogakushi and the kogakushi, or "Bachelor of Engineering." During this same period the college was given a botanical garden and the museum of natural history was reconstructed. The new college museum was filled with relics of the Ainu, minerals, and fauna that were collected by Benjiman Lyman during his stay.

Also during this period two of the college's most distinguished graduates left for the United states. Miyabe and Watase, as has been mentioned, studied at the Imperial 
University in Tokyo. They then went to Harvard where they studied Botany, then to John Hopkins University to complete zoological research. After the two men completed their extensive educations, which included several publications in their respective fields, they returned to sapporo to teach at the college. Other additions to the faculty were Hiroi Isamai and Nitobe from the class of 1881. Hiroi specialized in engineering and had worked for the Mississippi River Commission in st. Louis and at the Iron Bridge Works at Edge Moore, Delaware. He studied at the Royal Polytechnic Institutes of Karlsruhe and stuttgart, Germany.

Upon graduation from the Sapporo Agricultural College, Nitobe studied at the Imperial University in Tokyo and John Hopkins University. Nitobe travelled through Germany studying at the Universities in Bonn, Berlin, and earned his Doctor of Philosophy at Halle.

In 1887-1888 the Sapporo Agricultural College opened an Engineering Department. The department was first headed by Kano Tachibana, then by the Toronto-educated Milton Haight. This same year Brooks left Sapporo to become professor of agriculture at the Massachusetts Agricultural college. The new director of the college farm, Arthur A. Brigham, arrived in Sapporo with his family in 1889.

In 1890 the college was again threatened by political developments in Tokyo. In 1890 the first imperial parliament met in Tokyo. It was feared among many institutions that in 
order to lower taxes, certain government spending would be eliminated. The Sapporo Agricultural College faculty reacted and sent an urgent resolution to the Parliament:

We believe that our alma mater is an institution essential not only for the Hokkaido but for Japan at large, filling a unique position in the education system of the Empire. It stands for the upholding of higher technical and practical education. It aims to train men for developing the physical resources of the country. In an age like this, when people only talk, and politics and law engross the attention of the rising generation, in a land like this (Hokkaido), which hides within its bosom inexhaustible treasures, technical education is of inestimable value; and an institution equipped for this special purpose, must either be created anew or, better still, maintained if haply one already exists. Should, however, the public, more especially the Parliament - fail to recognize the worth of our alma mater, and make any encroachment upon its appropriations, we must have where-upon to fall back for the sources of its revenue. ${ }^{242}$

The letter to parliament was effective because the college survived the political storms of the time. With such minds as Nitobe, Hiroi, Wasate, Sato, and Miyabe, it is no wonder that the government sought to preserve the institution. The college survived because of the effective nature of its curriculum and the loyalty of its alma mater. With the growth of the college and the prestige of its faculty, the community prospered from this source of intellectual and practical wealth. Nitobe concluded that much of the development made in Hokkaido was from the college, and suggests that the impact of the college on Hokkaido, although difficult to access, was 
great. Nitobe wrote:

Here in the center of the Island are laboring between thirty and forty young men, i.e. fully one third of the alumni in different branches of the administration, education, colonization, agriculture, forestry, fishery, engineering, and geological survey. Though their individual names are hidden in a mass of paper by the wonderful working of red-tape machinery, yet any careful and impartial observer will never fail to recognize, that some of the most substantial work of the Hokkaido Government was primarily the fruit of their exertions. The town of sapporo reaps no small benefit from their presence; for they take a leading part in the chief local concerns of an intellectual nature. ${ }^{243}$

It is in the success of the college where the spirit of clark is hidden. The foundation he laid was strong enough to weather the crisis' that faced the college, and produce some of the leading scholars of the period. In this respect the Sapporo Agricultural College, not just the professors who started it, is a lasting example of the fruits of international cooperation, and their benefits to the nations that participate.

\section{CONCLUSION}

On March 9, 1886, at 3:00 a.m., William Smith clark, at age fifty-nine, died of heart disease. Although clark was not a great man, his life was full of significant achievements, including one of the greatest efforts in international relations. Clark's contributions to Hokkaido and education in Japan are found in the curriculum and strength of the Sapporo 
Agricultural College, the development of scientific agriculture in Hokkaido, his Christian leadership, and in the minds of the men and women who attended the college.

These students view Clark, and the ideas he brought to Japan, as the symbol of their intellectual independence and international openmindedness. Clark's students went on to become not only the great farmers of the Japanese frontier, but scholars like Nitobe, Uchimura, Niijima, Watase, Miyabe, and Sato who established international recognition and shaped much of their age. In these accomplishments lie the testimony of clark's eight month contribution to education, Christianity, agriculture, and American-Japanese cooperation in Meiji Japan.

clark is a particular example that serves to better explain more general historical movements in Meiji Japan. In coordination with the policy of fukoku kyohei, exchange took place between Japan and the West on a large scale. Clark is an example of the success that the Meiji leadership had with the importation of foreign ideas. He contributed to strengthening Japan by his work in Hokkaido, and thus is of larger importance than simply his regional success as founder of the Sapporo Agricultural College. In this sense, clark should be seen as part of a larger policy adopted by the Meiji leadership to strengthen Japan by importing foreign ideas and technology

It has been the purpose of this investigation to show 
that clark, through the establishment of the Sapporo Agricultural college, acted as a catalyst for liberal education in Japan, while making a significant contribution to the practical development of agriculture in Hokkaido. 


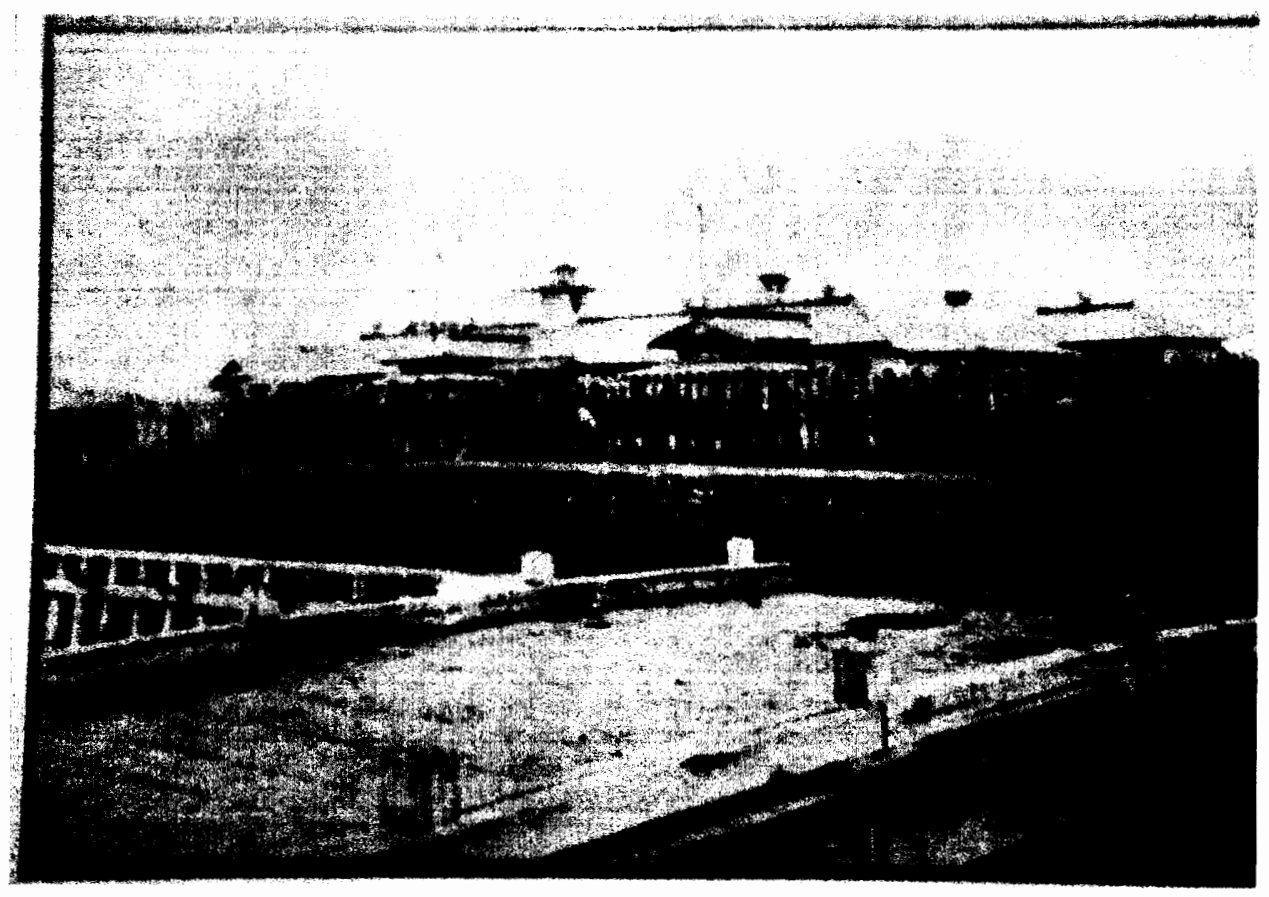

Figure 9. The parting picture taken at the honjin, the building where clark stayed while in Japan. (William Smith Clark Collection, Archives and Manuscripts Department University Library, Hokkaido University.) 


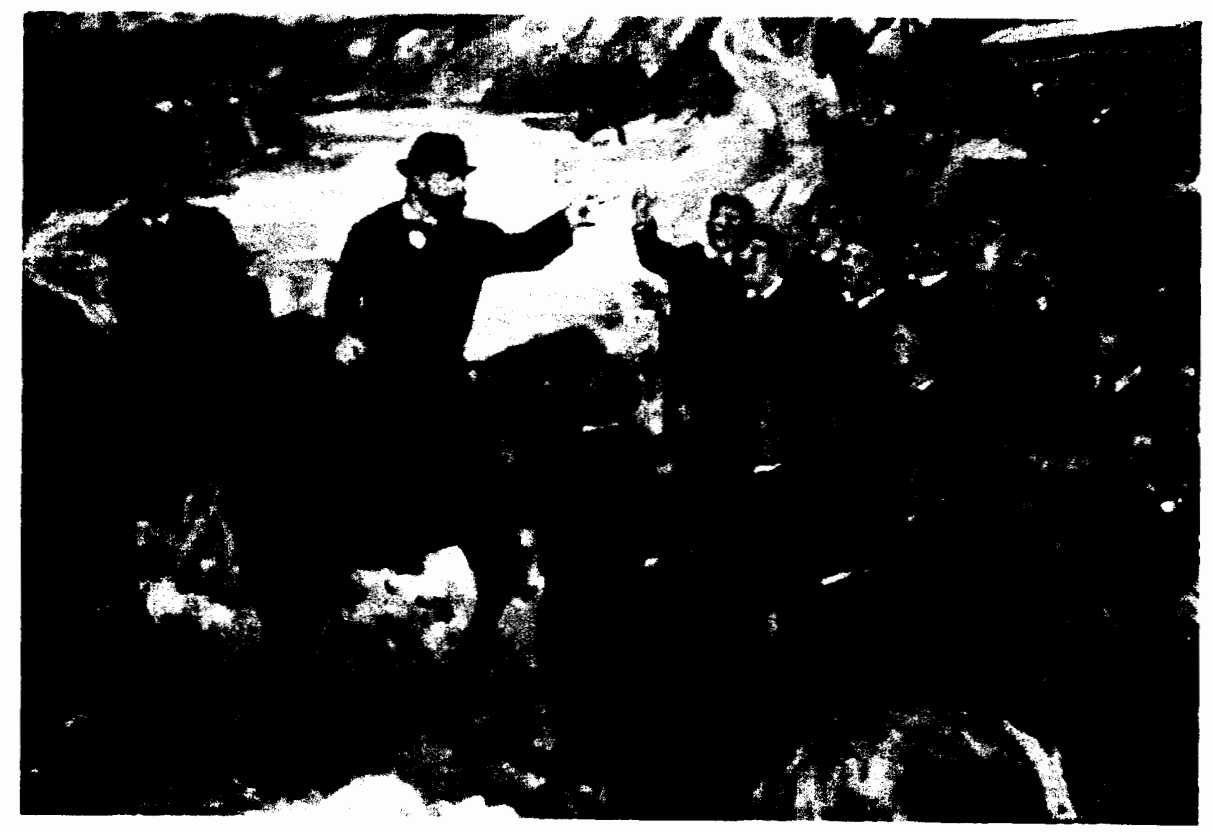

Figure 10. A painting at the old statehouse in Sapporo, Hokkaido, depicting clark speaking the words: "Boys Be Ambitious," during his departure. 
EPILOGUE

In one of the many ramen noodle shops that fill the city of Sapporo, Watanabe Shigeru, owner of The Yamasan-Fujiya group and graduate from Hokkaido University, explained to me the importance of Clark, and why he is treasured in Hokkaido.

"He is lasting, isn't he?" said watanabe. "Although my country has changed so much, the pioneer spirit of clark really hasn't."

Watanabe is the Chairman of the sister city commission in Chitose, Hokkaido, and is a firm believer in the importance of international cooperation. "Without men like clark and Nitobe," he explained, "Hokkaido wouldn't be what it is today."

Watanabe then told me how in 1926 Clark's bronze bust was placed on the campus of Hokkaido University. In 1942, however, the bust was melted down into material for the war effort in the Pacific.

"I was so young, I really didn't know what it meant. The war never really touched us in Hokkaido. Not as much as the other islands anyway," shrugged Watanabe.

After the war, the bust was re-sculpted and again placed on the campus. Like the sculpture, explained Watanabe, Clark's legacy in Hokkaido endures and it is for this reason he is celebrated as one of the great figures of Hokkaido's 
history. To the people of Hokkaido, Clark is what makes the northern island unique from the rest of Japan -- the accomplishment of an international effort. 
WORK CITED

\section{Secondary Sources}

Anthony, David Forsyth The Administration of Hokkaido Under Kuroda Kiyotaka, 1870-1882. New Haven, Connecticut: Ph.D. Dissertation, Yale University.

Burks, Ardath w. The Modernizers: Overseas Students, Foreign Employees, and Meiji Japan. Boulder, Colorado, London, England: Westview Press, 1985.

Caldarola, Carlo. Christianity: The Japanese Way. Leiden, The Netherlands: E.J. Brill, 1979.

Hall, Ivan Parker. Mori Arinori. Cambridge, Massachusetts: Harvard University Press, 1973.

Hokkaido Imperial University. The Semi-Centennial of the Hokkaido Imperial University, Japan 1876-1826. Sapporo, Hokkaido: Available at Hokkaido University, 1927.

Hokkaido Prefectual Governmental. Foreign Pioneers: A Short History of the contribution of Foreigners to the Development of Hokkaido. Sapporo, Hokkaido: Available at Hokkaido University, 1968.

Hunter, Janet E. Concise Dictionary of Modern Japanese History. Berkeley \& Los Angeles, California: University of California Press, 1984.

Kuwabara, Takeo. Japan and Western Civilization: Essays on Comparative Culture. Tokyo, Japan: University of Tokyo Press, 1938.

Jansen, Marius B., and Rozman, Gilbert. Japan in Transition From Tokugawa to Meiji. Princeton, New Jersey: Princeton University Press, 1986.

Livingston, Jon, Joe Moore, and Oldfather, Felicia. The Japan Reader: Imperial Japan, 1800-1945. New York, New York: Pantheon Books, 1973. 
Maki, John M. William Smith Clark: A Yankee in Hokkaido. Amherst Massachusetts: University of Massachusetts, Amherst, Massachusetts, 1953. (Also taped interviews with Professor Maki.)

Maasaki, Kosaka. "The Individual in Japanese Society," The Japanese Mind: Essentials of Japanese Philosophy and Culture. Honolulu, Hawaii: University of Hawaii Press, 1967.

Nakane, Chie, and Oishi, Shinzaburo. Tokugawa Japan: The Social and Economic Antecedents of Modern Japan. Tokyo, Japan: University of Tokyo Press, 1990.

Nihon Shidaizukan. Tokyo, Japan: Gakken Hon, 1993.

Nitobe, Inazo and Others. Western Influences in Modern Japan: A Series of Papers on Cultural Relations. Chicago, Illinois: The University of Chicago Press, 1931.

Nitobe, Inazo. The Imperial Agricultural college of sapporo, Japan. The Imperial Agricultural College, 1893. Available at the Archives Department at Hokkaido University, Sapporo, Hokkaido.

Nivison, David S., and Wright, Arthur F. Confucianism in Action. Stanford, California: Stanford University Press, 1959.

Osaka, Shingo. Kuraku Sensei Shoden. (A Full Biography of Professor Clark) Tokyo, Japan: Maruzen Company, 1956.

Oshima, Masarake. "Reminiscences of Dr. W.S. Clark," The Japan Christian Intelligencer. Vol. 1 No. 2, April 5, 1926.

Toshiyuki, Akizuki, "American Professors in the Development of Hokkaido: The Case of the Sapporo Agricultural College," Foreign Employees in Nineteenth Century Japan, Ed. Beauchamp, Edward R. \& Iriye, Akira, Westview Press, California, 1990.

Totman, Conrad D. Politics in The Tokugawa Bakufu, 1600-1843. Cambridge, Massachusetts: Harvard University Press, 1967.

Totman, Conrad D. The Collapse of the Tokugawa Bakufu, 18621868. Honolulu, Hawaii: The University of Hawaii Press, 1980 . 


\section{Primary Sources}

Clark, William S. "Constitution and By Laws of the Kaishikisha, 1876," William S. Clark Collection, Archives and Manuscripts Department University Library, University of Massachusetts at Amherst.

Clark, William S., "Sapporo Agricultural College, First Term Daily Routine," 1876, William S. Clark Collection, Archives and Manuscripts Department University Library, University of Massachusetts at Amherst.

Clark, William S., "Sapporo Agricultural College: Plan of Organization, 1876," William S. Clark Collection, Archives and Manuscripts Department University Library, University of Massachusetts at Amherst.

Clark, william S., "Temperance Pledge," November 28, 1876, William S. Clark Collection, Archives and manuscripts Department University Library, University of Massachusetts at Amherst.

Clark, William S., "The Agriculture of Japan," originally published by the Hampshire Agricultural Society, William S. Clark Collection, Archives and Manuscripts Department University Library, University of Massachusetts at Amherst.

Clark, William S. to Captain William B. Churchill, August 5, 1876, William S. Clark Collection, Archives and Manuscripts Department University Library, University of Massachusetts at Amherst.

Clark, William S. to Captain William B. Churchill, November 19, 1876, William S. Clark Collection, Archives and Manuscripts Department University Library, University of Massachusetts at Amherst.

Clark, William S. to Director Zusho Hirotake, September 15, 1876, William S. Clark Collection, Archives and Manuscripts Department University Ijibrary, University of Massachusetts at Amherst.

Clark, William S. to Director Zusho Hirotake (Honorable), April 22, 1877, William S. Clark Collection, Archives and Manuscripts Department University Library, University of Massachusetts at Amherst. 
Clark, William S. to His Excellency Kuroda Kiyotaka, Kaitakuno Chokuwan, July 15, 1876, William S. Clark collection, Archives and Manuscripts Department University Library, University of Massachusetts at Amherst.

Clark, William S. to His Excellency Kuroda Kiyotaka, Kaitakuno Chokuwan, September 8, 1876, Williams. Clark Collection, Archives and Manuscripts Department University Library, University of Massachusetts at Amherst.

Clark, William S. to His Excellency Kuroda Kiyotaka, Kaitakuno Chokuwan, September 12, 1876, william S. Clark Collection, Archives and Manuscripts Department University Library, University of Massachusetts at Amherst.

Clark, William S. to His Excellency Kuroda Kiyotaka, Kaitakuno Chokuwan, September 22, 1876, william S. Clark Collection, Archives and Manuscripts Department University Library, University of Massachusetts at Amherst.

Clark, William S. to His Excellency Kuroda Kiyotaka, Kaitakuno Chokuwan, May 22, 1877, William S. Clark Collection, Archives and Manuscripts Department University Library, University of Massachusetts at Amherst.

Clark, William S. to His Excellency Kuroda Kiyotaka, Kaitakuno Chokuwan, October 15, 1879, William s. Clark Collection, Archives and Manuscripts Department University Library, University of Massachusetts at Amherst.

Clark, william S. to Hubert Lyman Clark, August 20, 1876, William S. Clark Collection, Archives and Manuscripts Department University Library, University of Massachusetts at Amherst.

Clark, William S. to Hubert Lyman Clark (My Little Busy Bee), November 5, 1876, william S. Clark Collection, Archives and Manuscripts Department University Library, University of Massachusetts at Amherst.

Clark, William s. to Hubert Lyman Clark (My Beloved Boy), January 11, 1877, William S. Clark Collection, Archives and Manuscripts Department University Library, University of Massachusetts at Amherst.

Clark, william S. to Kaitakuno Haigan Yasuda, July 5, 1876, William S. Clark Collection, Archives and Manuscripts Department University Library, University of Massachusetts at Amherst. 
Clark, William S., Director of the Sapporo College Farm to Kaitakuno Hori Motoii, September 27, 1876, William S. clark Collection, Archives and Manuscripts Department University Library, University of Massachusetts at Amherst.

Clark, William S., Director of the Sapporo College Farm to Kaitakuno Hori Motoii, September 29, 1876, William S. clark Collection, Archives and Manuscripts Department University Library, University of Massachusetts at Amherst.

Clark, William S. to Kaitakuno Hori Motoii, December 28, 1876, William S. Clark Collection, Archives and Manuscripts Department University Library, University of Massachusetts at Amherst.

Clark, William S. to Mrs. Harriet Clark, July 5, 1976, William S. Clark Collection, Archives and Manuscripts Department University Library, University of Massachusetts at Amherst.

Clark, william S. to Mrs. Harriet Clark, July 23, 1876, William S. Clark Collection, Archives and Manuscript Department University Library, University of Massachusetts at Amherst.

Clark, William S. to Mrs. Harriet Clark, August 14, 1876, William S. Clark Collection, Archives and Manuscripts Department University Library, University of Massachusetts at Amherst.

Clark, William S. to Mrs. Harriet Clark, May 2, 1877, William S. Clark Collection, Archives and Manuscripts Department University Library, University of Massachusetts at Amherst.

Clark, William S. to Mrs. Harriet Clark, June 15, 1877, William S. Clark Collection, Archives and Manuscripts Department University Library, University of Massachusetts at Amherst.

Clark, William S. to Mrs. S.W. Leete (My Dear Sister Belle), August 5, 1876, William S. Clark Collection, Archives and Manuscripts Department University Library, University of Massachusetts at Amherst.

Clark, william S. to Reverend Niijima Jo, August 6,1878 , William S. Clark Collection, Archives and Manuscripts Department University Library, University of Massachusetts at Amherst. 
Clark, william S. to the Trustees of the Massachusetts Agricultural College, January 12, 1876, William S. Clark Collection, Archives and Manuscripts Department University Library, University of Massachusetts at Amherst.

Contract of Employment between Yoshida Kiyonari, Legation of Japan, and William S. Clark, March 3, 1876, William S. Clark Collection, Archives and Manuscripts Department University Library, University of Massachusetts at Amherst.

Hori Motoii, (Vice Governor of Hokkaido) to William S. Clark, March 25, 1877, William S. Clark Collection, Archives and Manuscripts Department University Library, University of Massachusetts at Amherst.

Hori Motoii and Satoh, H. to William S. Clark, March 25, 1877, William S. Clark Collection, Archives and Manuscripts Department University Library, University of Massachusetts at Amherst.

Kuroda Kiyotaka, Kaitaku Chokuwan to William s. Clark, President of the Sapporo Agricultural College, September 12, 1876, William S. Clark Collection, Archives and Manuscripts Department University Library, University of Massachusetts at Amherst.

Kuroda Kiyotaka, Kaitaku Chokuwan to William S. Clark, Vice Director of the Sapporo Agricultural College, September 23, 1876, William S. Clark Collection, Archives and Manuscripts Department University Library, University of Massachusetts at Amherst.

Kuroda Kiyotaka, Kaitaku Chokuwan to President William Smith Clark, May 21, 1877, William S. Clark Collection, Archives and Manuscripts Department University Library, University of Massachusetts at Amherst.

Legation of Japan in Washington D.C. to William S. Clark, January 14,1878 , William S. Clark Collection, Archives and Manuscripts Department University Library, University of Massachusetts at Amherst.

Mori Arinori to William S. Clark, February 3, 1872, The William S. Clark Collection, Archives and Manuscripts Department University Library, University of Massachusetts at Amherst. 
Ono, K. to President William Smith Clark, December 5, 1877, William S. Clark Collection, Archives and Manuscripts Department University Library, University of Massachusetts at Amherst.

Sanjo, Sanetoshi, Prime Minister of Japan to Director Zusho Hirotake, August 25, 1876, william S. Clark Collection, Archives and Manuscripts Department University Library, University of Massachusetts at Amherst.

Watase, T. to President William S. Clark, December 2, 1877 , William S. Clark Collection, Archives and Manuscripts Department University Library, University of Massachusetts at Amherst.

Yoshida Kiyonari to William S. Clark, February 12, 1876, William S, Clark Collection, Archives and Manuscripts Department University Library, University of Massachusetts at Amherst.

"Your Obedient Pupils" to Director Zusho Hirotake, November 1 , 1876, William S. Clark Collection, Archives and Manuscripts Department University Library, University of Massachusetts at Amherst.

"Your Obedient Pupils" to President william Smith Clark, December 19,1876 , William S. Clark Collection, Archives and Manuscripts Department University Library, University of Massachusetts at Amherst.

Zusho Hirotake, Kaitaku Shiohangan, by order of General Kuroda Kiyotaka to President William S. Clark, September 11, 1876, William S. Clark Collection, Archives and Manuscripts Department University Library, University of Massachusetts at Amherst.

Zusho, Hirotake, Kaitaku Shiohangan to President W.s. Clark, November 7, 1876, William S. Clark Collection, Archives and Manuscripts Department University Library, University of Massachusetts at Amherst.

Zusho Hirotake, Kaitaku Shiohangan to President william S. Clark, April 10, 1877, william S. Clark Collection, Archives and Manuscripts Department University Library, University of Massachusetts at Amherst. 
APPENDIX A

CLARK'S DESCRIPTIONS OF HOKKAIDO 


\section{CLARK'S DESCRIPTIONS OF HOKKAIDO}

While in Hokkaido, Clark made many observations that not only tell of the island's development, but of how clark, as an academic, viewed the Japanese. His observations shed interesting light on the accomplishments of the Meiji leadership in Hokkaido, and how Clark, as an outsider, viewed them.

HISTORICAL IMPORTANCE OF CLARK'S OBSERVATIONS IN HOKKAIDO

In Hokkaido, Clark made many valuable observations about the people, customs, standard of living, and progress of settlement in Hokkaido. Clark's observations are fascinating because in them a glimpse of nineteenth century Japanese life can be had. The life not of worldly scholars and famous statesmen, but the average people, the farmers, who by the nature of the Meiji reforms carried the majority of the irksome economic burden of change on their tired and crooked backs. Their lot was especially bad in Hokkaido, where the rapid settlement left many unprepared for the rugged northern climate.

Clark spent most of his time absorbed in business, but frequently travelled and took notes of his observations or wrote home to his family about the Japanese. To his children he described a Japanese kite, to his brother the variety of 
foods that the Japanese ate, and to his wife everything from the tea harvest to shinto customs he observed in everyday Japanese 1 ife.

Clark's observations should not only be seen as evidence to the backwardness of Hokkaido, but to the progress of its settlement and to the testimony of the work that faced Kuroda and his foreign advisors. Clark and his observations become a valuable source of information as to the progress of the settlement of Hokkaido, the general condition of agriculture in Japan, and the brutal lot of the farmer. First hand observations of Hokkaido during this period are rare, especially by a scholar as talented as clark.

The first set of remarks are casual observations that clark wrote to his son. They are not scientific and are geared to play well in the ears of a child. Nonetheless, they are valuable and interesting. On November 5, 1876, Clark wrote to his son about his travels up the Ishikari River on the Emperor's birthday "which everybody celebrates as a holiday."244 Clark, wheeler, and Naito, "with workmen and saws and axes"245 trekked up the Ishikari to gather timber. The Ishikari flooded, however, and the men had difficulty reaching their destination. They managed to cut the timber

244 William Smith Clark to Mr. Hubert S. Clark (My Dear little Busy Bee), November 5, 1876, william S. Clark Collection, Archives and Manuscripts Department University library, university of Massachusetts at Amherst. 
but that night "it rained and the river soared seven feet, so we could not ride home at all."246 The men eventually hired a canoe and floated home to safety. While canoeing down the Ishikari Clark made these observations:
As we were sailing down the Ishikari the people were catching salmon in many places, and all of them had little temples built on the bank, where, they prayed for good luck to a piece of white paper, which they thought the god of fisherman would pay attention to. Over each temple was a little red flag, and sometimes inside was a paper lantern for the use of the god at night. The temples were generally not more than three feet high and two feet wide and built of reeds, the ends towards the water being left open. The entire cost of the temple, flag and god was not more than ten cents. ${ }^{247}$
clark also included in letters samples of lichen, photographs, and coins of which the whereabouts are unknown. Typically warm, he asked his son to take care of his sisters "like a good republican," 248 and see to it that the farm was cared for. On January 1, 1877, Clark again wrote to his "beloved boy:"

I wish I could send you a kite, for they have splendid ones here. They are very light and fly as well as butterflies. They are very funny...

In the market here they have strange things for sale to eat. Of quadrupeds, the most common is the deer. Venison is the cheapest meat. Then there are lots of beautiful, snow-white hares. Of birds, we see little sparrows, wild ducks, geese, swans, and cranes. These last are taller than you and are white with black wings. But the strangest things come out of the Japan Sea and I wouldn't

$\begin{array}{ll}246 & \text { Ibid. } \\ 247 & \text { Ibid. } \\ 248 & \text { Ibid. }\end{array}$


like to eat them. Besides salmon, codfish and many other nice fish, there are some hideous ones... the cuttlefish are horrid. They are white and soft, but when boiled turn red and solid like Indian rubber. Their arms are four or five feet long and covered with suckers so I think one could kill you in the water. Then such tremendous crabs with legs two feet long! They look like monstrous spiders. Perhaps you have seen some of the same kind in the Amherst College cabinet. The Japanese and the Ainu like such things, but I don't want to taste them. what I like best from the market is fruit. We had a few nice, white grapes. Then we had plenty of kaki or persimmons. Now we have sweet oranges without seeds, for a cent a piece, and I buy them by the hundred. They are very delicious and very healthy. We have also curious lemons, which are very tender, with a soft, thick skin, full of oil. ${ }^{249}$

\section{LECTURES AND WRITINGS ON JAPANESE LIFE BY CLARK}

Clark made more scientific remarks upon returning to Amherst. In September, 1877, he gave a lecture in a local church that filled the house. A week later he gave another talk to the Hampshire Agricultural Society where he praised aspects of Japanese agriculture. "The Japanese people are contented, economic, and industrious," he said in front of a standing room only crowd. "Science follows art, never precedes it, and the Japanese have had the art to become good farmers without a very scientific knowledge of farming."250

In 1878 Clark gave a lengthy lecture entitled "The Agriculture of Japan," in Waltham, Massachusetts. The lecture

249 William Smith Clark to Hubert S. Clark (My beloved Boy), January 11, 1877.

250 Maki, William Smith Clark, Chapter VIII, p. 23. 
was later published by the Massachusetts Agricultural Society. This lecture offers some of Clark's reflections about the society, land, and history of the Japanese as clark saw them while in Hokkaido. Clark expressed the purpose of his lecture to present a "few facts concerning the situation, extent, and resources of [Japan], the characteristics and conditions of its inhabitants, and especially of its farmers, and the peculiarity and results of its ancient system of agriculture."251 The lecture was sponsored by the Hampshire Agricultural Society and was given in a small, community grange hall. The lecture captured the frontier intellectualism that clark came to exemplify everywhere he went. Clark wrote:

The Japanese people are a peculiar and remarkable race, whose origin and early history are involved in obscurity. They are more vivacious, progressive, and courageous than the Chinese, and have a language quite of their own. They have a high sense of honor, are extremely polite and amiable, and intensely patriotic. They are apt scholars, ingenious artisans, successful farmers, excellent sailors, and brave soldiers. ${ }^{252}$

The living conditions of the Japanese farmer in Hokkaido was explained as follows:

There houses are mere shells of wood, without cellars, chimneys, glass, or paint. The doors, windows, and partitions are all made to slide, and consist chiefly of light sash covered with thin,

251 The Agriculture of Japan, by william Smith Clark, 1879, william S. Clark Collection, Archives and Manuscripts Department University Library, University of Massachusetts at Amherst.

252 Ibid., p. 5-6. 
translucent paper, and without hinges, locks, or permanent fastenings... The roof is the most substantial portion, and holds the house together in its place by its weight. In the older towns and villages excellent tiles of stone-ware are used for roofing; but in the country isolated farm buildings are often heavily thatched with straw or grass. In Yezo [Hokkaido] the roofs are often covered with split shingles, or pieces of birch-bark, which are kept in position by logs of wood or flat stones... A Japanese farm house is just about as comfortable in all weathers as a good canvas tent, and the ordinary life of the people is a sort of gregarious camp-life. very little privacy is possible, and the household conveniences are few of the simplest sort. A portion of the floor is generally a bare earth; while the rest is of wood, and raised above the ground about eighteen inches. This is usually covered with thick straw-matting, upon which the inhabitants sit and sleep as circumstances and feelings dictate. They do not use chairs, but sit down upon their heels, kneeling, and resting the instep upon the floor, with the toes projecting behind. The bed, when one is wanted, consists of a thin mattress of cotton or straw, which is spread upon the floor: and the covering is comfortable, or quilt, of cotton. The pillow is a block of wood four or five inches high, three inches wide, and from seven to nine inches long, somewhat convex on the bottom, and concave on the top. On this is laid a roll of cotton to serve as a pad for the head. In reposing, this pillow is placed just under the ear, and is said to be comfortable for those who are accustomed to it. The object of such an extraordinary invention seems to be to prevent the disarrangement of the hair, which is very elaborately dressed, especially by the women. During the day the bedding is stored in closets constructed for this purpose, and which serve also to contain any articles of spare clothing. There are usually no tables in a Japanese farm house; but the food is brought in on lacquered trays with legs, which raise them a few inches from the floor. The dishes from which the food is eaten are of lacquered wood of the size and shape of a deep tea-saucer, and the knives, forks, and spoons of Western civilization, are entirely replaced by the much cheaper chop-sticks of cedar wood. It is the business of the cook to cut up and prepare food so that it can be picked to pieces, and poked into the mouth with the sticks, assisted 
by timely inhalations of the breath. ${ }^{253}$

clark explains the eating habits of the Hokkaido farmer

as follows:

The universal substitute for bread is steamed rice, which is eaten without salt, sugar, milk, butter, or oil. It constitutes by far the greater part of the daily food of the agricultural population, and is both easy of digestion and very nutritious. But every Japanese demands with his rice at every meal a liberal supply of stinking salt pickle made of radishes. Beans and peas also constitute an essential part of the food of vegetarians, and these are eaten in a great variety of sorts and in numerous ways. Soy, the common sauce for fish and vegetables, is produced by the fermentation of beans and wheat, with the addition of salt and vinegar. The Japanese eat everything edible that grows in the water, and are very fond of raw fish, and also of seaweed, which is cooked in many ways. As they do not use milk, they make cheese from the flour of beans and peas; and, and as a substitute for butter and lard, they catch the oil obtained from the seed of a sort of cabbage, which is largely cultivated for this purpose...

Perhaps the most extraordinary thing in regard to the food of the Japanese is their preference of green fruit to that which is ripe. Peaches are considered edible as soon as the stone is too hard to break with the teeth; but before this they are considered unhealthy. Plums, apricots, peaches, and melons are preferred in an unripe state. Apples and pears are also consumed when very hard, and indigestible for anyone but a rice eater. ${ }^{254}$

clark continues with tea, sake, and its availability:

The universal beverage of Japan is tea, which is drunk from small cups in the form of strong decoction, without milk or sugar. As a matter of politeness, tea, with cake or candy, is offered to every visitor at the house or office or store at all hours of day or night. The tea of the farmer consists of stems and coarse leaves, the refuse of

253 Ibid., p. 10-11.
254 Ibid., p. 11-12. 
the choicer sorts, and is sold for a few cents per pound; while that of the wealthy - consisting of tender leaves carefully rolled and culled by hand, and, for the finest brands, raised in the shade costs as many dollars per pound. The Japanese have neither grape nor palm wine, and therefore manufacture an alcoholic beverage from rice by fermentation and distillation. This is called sake, and is consumed in considerable quantities, notwithstanding the recently propounded doctrine that vegetarians have but little desire for alcoholic stimulants. ${ }^{255}$

The clothing and hairstyles of the Hokkaido farmer were explained as follows:

For a dress-suit, the farmer has a short, loose blouse and tight pants of blue cotton ornamented with certain marks or figures in white. For a stylish headdress, he wears a blue cotton handkerchief or towel, tied on variously according to weather. He prefers, however, to appear without any covering to his shining plate and comical topknot, which, in absurdity, eclipses the chinaman's pig-tail. The old style Japanese shaves the hair from his temples and from the top of his head, and then binds the long hair tightly into a cue behind. This is heavily waxed, and tied into a roll, without braiding, and then brought up over the crown of the head, and laid carefully on the bald place in front, the end being cut square. This unique style is said to have been originally a military device to keep the hair out of the eyes, as it certainly does. When at work in the fields, both sexes prefer to reduce their clothing to its lowest terms, and are evidently not afraid of getting sun-burnt; but in very hot weather they often wear a flat straw hat two or three feet in diameter, which is sometimes attached to the head by a framework of strings, so as to allow the freest ventilation. In rainy weather they wear a thick garment of woven grass, which sheds water precisely like a thatched roof. They also wear waterproof hats and coats of heavy oiled paper, from which material their umbrellas both for sun and rain are also manufactured. In the warm wet rice-fields, laborers naturally go barefoot; but on the roads and mountains, especially in winter, they 
require protection for the feet. As leather is a rare article in a country where animals are not slain for food, the Japanese have ingeniously woven and braided saddles, shoes, boots, and leggings, out of rice straw and the leaves of the cat-tail flag... Even their horses and cattle, when employed on hard roads, are shod with shoes which answer an excellent purpose for a single day, though made simply of rice-straw. ${ }^{256}$

The Japanese heated their homes with charcoal and as Clark observed, because of insufficient ventilation, this contributed to health problems on a national scale. Clark wrote:

Charcoal is the universal fuel, and is used with extreme economy, either in small chafingdishes, or upon a sort of open hearth in the center of the room, consisting of a wooden frame two or three feet square, and filled with sand or ashes. The smoke and poisonous gases generated by the combustion are allowed to mingle with the air of the house which is shut, in cold weather, as tightly as possible. The preservation of the race under these circumstances results entirely from the wretched construction of the houses, which are as full of holes as a sieve, and therefore well ventilated. The habit of huddling around these burning coals has undoubtedly tended to the development of diseased eyes, which are very common, and caused much of that hollow-chested-ness which is a national deformity. ${ }^{257}$

This does not mean that the Japanese were filthy people.

Clark explained the cleaning habits of the Japanese in Hokkaido as follows:

The universal detergent in Dai-Nippon is hot water; and, if this will not start the dirt, and sand cannot be applied to aid it, the virtues of alkali from wood-ashes are well known and employed in a practical way. The Japanese are scrupulously

256 Ibid., p. 13-14.
${ }_{257}$ Ibid., p. 10.


clean in their persons and dwellings. They have a saying, that, when the houses of a nation are kept clean, you may be certain that the government is respected, and will endure. According to their history, their government is the most permanent in the world, having continued under one and the same dynasty for 2538 years; the present emperor Mutsuhito being the hundred and twenty-third ruler descended in a direct line from Jimmu Tenno, the first Mikado. Cleanliness with them, as with us, is akin to godliness. There cannot be found in any other country so frequently and thoroughly washed a people as the Japanese. Every man, woman, and child is expected to be soaked in hot water everyday so long as it lasts. They are, however, in this business of bathing as in everything else, very economical, and compel a small quantity of water to cleanse many skins. In the cities and villages public baths exist, where hundreds of persons of all ranks, ages, and conditions, and of both sexes, plunge into the same tank, until the hot water reminds a Yankee observer of the water in a wash-tub in which a week's washing for a large family has been done. They adopt, however, the same method for obviating the objection to this course that is used by the washer-woman; namely, to rinse the washed articles in clean water, which is furnished in a small tub to each person on emerging from the common tank. ${ }^{258}$

Clark even wrote about the eta or burakumin, the Japanese social outcasts that were regarded as sub-human and did not enjoy the same rights and social privileges as most Japanese. Although they were given legal equality after 1871, discrimination continued at the work place, residences, and in marriages. clark's comments show that discrimination persisted against the burakumin despite legal equality.

Those persons who killed and skinned animals, and made leather, were considered such miserable outcasts, that they were forbidden to eat or sit with other persons, or to enter their houses. They were not enumerated in the census, and enjoyed no 
legal rights; while the land on which their villages stood was never measured, nor mentioned in documents relating public roads. What must have been the astonishment of the great embassy from Japan in 1872, to learn that the President of the United states had once been a tanner! ${ }^{259}$

More than just remarking on the general daily habits of the Japanese, Clark also commented on religious practices, the Japanese appreciation of natural beauty, and aesthetic tastes in art and gardening. clark wrote:

The Japanese are very fond of fine scenery, and often undertake excursions to such localities as afford good views of it. They are also accustomed to build big temples and shrines upon elevated sites in the vicinity of towns and cities, and to visit them frequently for worship and pleasure. These high places are usually approached by wellconstructed roads and walks, and massive stairways of cut stone, and surrounded by magnificent groves of gigantic evergreen trees, which have been carefully protected for centuries. Camellias, azaleas, double-flowering apples and cherries, and other ornamented trees, shrubs, and herbaceous plants, in great variety, are also freely used for adornment. The people appreciate and enjoy these things of beauty, and cheerfully contribute to the maintenance of the priests who care for them; and, as a matter of course, they never steal nor injure them. 260

Clark commented on how plants were kept and the peculiarity of the Japanese aesthetic in gardening to manipulate, rather than repulse, nature. Again, although he was uneducated in Japanese culture, and few Westerners were at the time, his remarks are intelligent and worth note. Clark wrote:

$$
\begin{aligned}
& 259 \text { Ibid., p. } 15 . \\
& 260 \text { Ibid., p. } 22 .
\end{aligned}
$$


In propagating plants, both from seed and by extension, the Japanese are exceedingly skillful; and they also cultivate and transplant trees with great success. They are very fond of oddities which it requires great time and care to produce; such as old, dwarf trees grown in minute pots, small trees standing on three or four long slender roots resembling spider legs, and trees trained into the form of miniature houses, boats, or animals. They delight in coaxing a single branch of a pine to extend itself a long distance from the trunk in a horizontal direction, so as to look as artificial as possible. ${ }^{261}$

Clark's comments on Japanese life are intelligent, witty, and sometimes a little high-handed, but display a fair and sincere appreciation for things Japanese. He did not view the traditions as backwards, but the product of a people who, through the lessons of time, had learned to economize and make do with the conditions that surrounded them. Clark was a practical man and appreciated raincoats made from straw thatching. He believed these the product of a clever people, and was moved to ask the farmers of Massachusetts to adopt certain Japanese methods.

In the field of agriculture clark's notes are more detailed. He was employed by the Kaitakushi for the purpose of agricultural advancement, and had more first hand experience with the farming industry. clark summarized Japanese agriculture as follows:

In practical agriculture the Japanese are remarkably skillful, and have numerous methods and customs which might well be imitated by us. There cannot be found in any other country extensive fields which produce more human food to the acre,

261 Ibid., p. 22 . 
or which are more free from weeds, or which maintain their fertility from generation to generation more perfectly, or which more completely charm the eye of an intelligent traveller. The most important characteristic which distinguished Japanese farming are the following; viz,, first irrigation; second, fertilization by Iiquid manures repeatedly applied to the growing crop; third, cleanliness of culture; fourth, thoroughness of tillage; fifth, constant cropping of lands without deterioration; sixth, extreme simplicity and economy of method, involving the minimum of expense for seed, manure, and tools; seventh, the extraordinary scarcity of domestic animals and teams with agricultural machinery. ${ }^{262}$

Clark was impressed by Japanese economy of resources. He explained, the Japanese farmer cares for his crop to the extent that every "individual stock of valuable vegetation receives attention from the farmer, and every useless plant is eradicated before it blossoms." 263

Clark paid special attention to the tea industry which he described as the "second most important industry of Japan."264 In order to produce the best quality tea, the farmer was forced to comply with painstaking traditions that Clark describes in detail. clark wrote:

During the Spring and early summer the fields are entirely covered over with mats or rice-straw spread upon bamboo poles at a height of six feet above the earth. This gives the country a very extraordinary appearance by no means attractive. The object in thus shading the shrubs is to partially blanch the foliage, and to check the development of the chlorophyll so as to render the leaves more tender and delicate in flavor. The

262 Ibid., p. 19.
263 Ibid., p. 20.
264 Ibid., 21.


crop is thus diminished in quantity, but enhanced in quality and price. About the middle of May, when the young shoots are three or four inches long, the women and children begin the first picking, which furnishes the best tea. The pickers seize the shoots just below the middle, and with a quick jerk strip off two or three leaves and the soft tip, and drops them into a basket... The women earn about six cents per day in picking tea, and the men in the curing-houses receive from twenty to fifty cents per day according to their skill. The tea is packed for market in closed boxes or jars, which are tightly covered with waterproof paper. Of course the best tea can only be enjoyed by very wealthy people, and is never sold for exportation. ${ }^{265}$

One striking aspect about clark's descriptions, which have been given here in length, is that many of these same characteristics that fascinated clark still exist, and are in wide practice. Housing and the general standard of living has improved, but tastes in food, aesthetics, and other characteristics have changed little in the past century. clark, in respect to the observations he made while in Hokkaido, remains not only a historically important individual because of what he accomplished, but also because of what he recorded upon his visit.

\section{CLARK AND OBSERVATIONS OF THE AINU}

Before the settlement of Hokkaido by the Kaitakushi, the island had been inhabited by the Ainu, the aboriginal people of the Japanese archipelago. The Ainu had traded with the bakufu and enjoyed friendly relations with the Japanese until

265 Ibid., p. 23-24. 
the development of Hokkaido. In 1873, three years before Clark arrived in Sapporo, the Ainu made up 95 percent of Hokkaido's population. In 1897 this number was reduced to 22 percent because of the rapid Japanese settlement and reform in land owning laws that forced the Ainu from their native hunting grounds. By 1900, roughly 17,500 Ainu remained. ${ }^{266}$ The Ainu were killed off by alcoholism, tuberculosis, and venereal disease. The Kaitakushi attempted assimilation of the Ainu with the migrating Japanese, but the attempts proved unsuccessful.

In 1899, after the dwindling number of Ainu became known to the government, the Ainu Protection Law was passed. The law was in effect until 1937, but failed to have any noticeable impact on the miserable lot of the Ainu. The position of the government remained assimilation, and this was supported by many Ainu leaders, but this led to the subsequent destruction of the Ainu populations and their culture.

While Clark was in Hokkaido he had several opportunities to observe the Ainu. Clark, Wheeler, and Penhallow all became interested in the $A i n u$ and collected many $A i n u$ articles which they brought back to the United States. On one occasion, while Wheeler and Clark were exploring the Ishikari, an Ainu guide saved Wheeler's life when he was cast into the flooded river. When clark returned to Amherst, he gave several 
lectures on the Ainu using the articles he brought back to impress the fascinating aspects of their culture upon his audience.

On August 14,1876 , in a letter to his family, clark wrote of his first contact with the Ainu:

We saw several hundred of the hairy men with their women and children and found them fine looking savages of peaceful dispositions and a language very smooth and agreeable to the ear. The men wore earrings two inches in diameter, with long black hair and beards. Their clothing is made of cotton twine and threads of bark woven by the women. The women wear their hair just like the men, that is, cut, with a knife, square in the neck. They tattoo the red portion of the lips blue, and still further increase their beauty by enlarging the painting to the diameter of an inch or more around the mouth. They also tattoo their hands and arms half way to the elbow in different styles according to their taste and skill. They are fond, like other women, of bracelets, earrings, \& \& \& Last year Governor Kuroda brought six hundred of these people from Saghalien (Sakhalin), which was ceded to Russia, and most of them are now living about fifteen miles from Sapporo. So I shall see more of them and obtain specimens of their handiwork. ${ }^{267}$

In the early stages of Kaitakushi development, Ainu were used for labor around Sapporo. Clark, writing to his family, was apparently witness to this policy. On August 20, 1876, Clark wrote further descriptions of the Ainu to his son:

I send with this letter some pictures of the Ainu, or hairy men, who live in this country. They are very good-natured people and do no harm to anybody. They are magnificent boatmen and catch a great many fish with hooks, and spears and nets. They kill bears with poisoned arrows. Their clothes are made of bark and skins, and their huts are built of poles and covered with dried grass and rushes. Ainu boys are large as you and do not have any 
clothes at all in summer, and they play in the mud and water like ducks. ${ }^{268}$

Clark gave a more detailed description of the Ainu in his lecture on Agriculture in Japan. Although Clark's observations are not ethnographically sound, they are important, nonetheless. Clark wrote:

The first settlers, or aboriginal, of Japan, seem to have come from central Asia, by way of the great northern island of Saghalien (Sakhalin), which is separated from siberia only by a few miles of shallow water. There is satisfactory evidence, in the ancient kitchen-heaps of this race on the island of Hondo (Honshu), as well as in the traditions of the people, that they formerly occupied the country in very considerable numbers. They were savages, subsisting almost entirely upon fish, and the flesh of wild animals. They lived in rude huts of poles, thatched with grass, and covered with bark, and were clad in garments woven from the bast of trees, or in such as they made from the skins of salmon, seals, and the beasts of the forests. These peculiar people have been gradually amalgamated with the more civilized and warlike races which entered Japan from the south; so that none can be found on Hondo. A few thousand, however, still exist on the island of Yezo. They call themselves Ainos (Ainu), and are remarkable for their unusual hairiness, by which they are readily distinguished from the Mongolians. They seem to have made little or no progress in the art of civilization during the last thirty centuries. Their agricultural skill is exhibited chiefly in digging native lily-bulbs, yams, and burdock roots, and in gathering edible seaweed and wild fruits. Their domestic animal, if he can be so called, is a wolf-like dog, which is able to hunt and fish for himself, and is sometimes useful in dragging sledges, but, as often happens among civilized men, appears to be principally prized for the pleasure of his company. ${ }^{269}$

These descriptions give some indication that at the time

${ }^{268}$ William Smith Clark to Hubert Clark, August 20, 1876.

269 Agriculture in Japan, by william Smith Clark, 1879. 
of Clark's arrival in Sapporo the Ainu, although subdued by the Japanese, were an important group in Hokkaido. Clark came into contact with the Ainu several times as they were frequently used by the Kaitakushi for guides and other useful enterprise. Because the Ainu culture is all but extinct today, clark's observations of their culture are important, and should be recognized in any history of Hokkaido. 
APPENDIX B

CLARK'S SERVICE RECORD IN THE CIVIL WAR 
CLARK'S SERVICE RECORD IN THE CIVIL WAR

In the 1860's, Japan was not the only country suffering social upheaval, conflict, and ultimately war. By 1860, the war between the slave-holding states in the south, and the pro-Union states in the north, was, for historical simplicity, inevitable. It was natural that clark, being from Massachusetts and against the institution of slavery, aligned himself with the ideology of the North.

A person with Clark's personal sense of righteousness and duty, not to mention keen want for adventure, was bound to become involved with the Civil war. Clark not only expressed a want to join the fighting, which by 1861 was under way, but volunteered to create a Massachusetts Calvary Brigade under the direction of the United States government. When the war progressed, however, and the Union Army was stunned with Confederate victories at unlikely battles like Bull Run, Clark realized there was no time, and in 1861 enlisted in the Twenty-First Regiment of the Massachusetts Volunteers as a Major. ${ }^{270}$

on December 21, 1861, Clark wrote to President Stearns at Amherst College: "I am in the great army as one of the representatives of the College and endeavor to do my whole

270 Maki, William Smith Clark, Chapter III, p. 1-2. 
duty as a patriotic citizen soldier fighting for republican institutions and for human freedom."271 Eventually, as with most people subjected to the insanity of war, clark's romance for the conflict changed, but his sense of duty, and the belief in the cause of freedom, did not.

on February 7, 1862, Clark's regiment departed for Roanoke Island and on the next day the Massachusetts volunteers, as a member of the Union Army, engaged parts of the Confederate Army in what became one of Clark's most heroic moments in the war. On March 4, 1862, Clark was promoted to Lieutenant-Colonel and given command of the Twenty-First Regiment. After the Battle of Roanoke Island Clark wrote to his father: "It is a glorious sight to see a thousand men marching straight forward into the fire from a thousand muskets aided by a battery of cannon and men never feel more manly than when they are doing it." 272 clark went on to write: "When you listen to the roar and rattle of the battle and see the fire and smoke and hear the music of the [musket] balls you wonder that any should escape unhurt and yet that is a terrible fight in which one in ten of the combatants is wounded. "273

On March 15, 1862, Clark again distinguished himself in battle, this time at Newbern. Upon advancement on an

271 Ibid., Chapter III, p. 5.
272 Ibid., Chapter III, p. 8.
273 Ibid., Chapter III, p. 8.


Confederate position Clark and his men engaged in a pounding exchange of musket fire that nearly cut the Twenty-First Regiment down. In a daring tactical move, clark, in an attempt to evacuate his position, ordered a general charge on enemy lines. The advance proved successful and even clark, the officer in command, was seen jumping upon a battery position and rendering it inactive single-handedly. within minutes, however, Clark's regiment again came under heavy fire, this time superior, and Clark orchestrated a clever evacuation, well organized, that lead his men to safety. By sundown the Union Forces carried the day. ${ }^{274}$

On April 28, 1862, Governor John. A. Andrew of Massachusetts wrote President Lincoln to request that Clark be promoted to full Colonel. The same day the Governor received a letter from General Burnside approving the recommendation. As Colonel, Clark saw action at Chantilly where his regiment was pounded by Confederate guns, and at Antietam where, in probably his greatest loss of the war, Manross, Clark's friend from Amherst, was killed in battle. By the time clark fought at Fredericksburg his thoughts about war had begun to change, but clark, although disdainful of war itself, never lost sight of the goals set by the Union Army. "I am willing," he wrote to his father, "to spend the rest of my life, if need be, in the horrid work of war to put down the proslavery

274 Ibid., Chapter III, p. 9-10. 
rebellion."275

On April 22, 1863, for reasons that are still unclear, Colonel Clark asked to be "honorably discharged [from the] service of the United States."276 on September 23, 1862, General Burnside had written Major-General McClelland from Antietam and recommended that Colonel Clark and several others be promoted to the rank of Brigadier General. Although clark's conduct in the war was highly praised by Burnside, clark's promotion never materialized, and this may have been part of the reason that he chose to resign. It is also likely that Clark, because he had seen action at Roanoke Island, Newbern, Camden, Manasses, Chantilly, South Mountain, Antietam, and the killing fields outside Fredericksburg, had become burned out, was tired of the fighting, and wanted out. Although he proved to be a outstanding soldier, Clark always considered himself a scientist and war, may have been revolting to the aspiring academic. When Clark's Twenty-First Regiment first engaged the Confederates at Roanoke they were roughly seven hundred strong, after Fredericksburg, two years later, this number had been reduced to two hundred.277

\footnotetext{
275 Ibid., Chapter III, p. 10.

276 Ibid., Chapter III, p. 19.

277 Ibid., Chapter III, p. 21.
} 
APPENDIX C

CLARK'S DESCRIPTION OF THE EMPEROR OF JAPAN 


\section{CLARK'S DESCRIPTION OF THE EMPEROR OF JAPAN}

On July 23, 1876, Clark wrote to his wife:

The day before yesterday we had a fine opportunity to see the Mikado and his wife with their retinue, carriages, guard and the highest officials. He has been absent several weeks visiting the northern portion of the Empire. The day of his arrival home was proclaimed a holiday and everybody turned out to see the sights. The Empress and four ladies of honor drove to the depot and stood on the left of the gate through which he was to enter. They wore no headdress, but their hair was elaborately plastered and spread... Their faces were enameled snow-white, their lips painted of a brilliant vermillion and their teeth, I suppose, jet black, as that is the fashion of all married ladies. They displayed no jewelry, nor ribbons, but wore white wastes and crimson satin skirts.

The Mikado, ungallant man, did not condescend to notice the ladies, but marched coldly past them as if wholly absorbed in more important matters. He is unusually tall for a Japanese and has a good pair of legs upon which he stands firmly and walks gracefully. His dress was rich, but plain and without any trimming but black braid. He wore a black cocked hat with a neat plume of black and on the whole appeared well. He is 26 years old and in vigorous health, and is highly revered by the people. His state carriage was made in London and is very rich in appearance. It was drawn by four superb bay horses imported from California. He had a bodyguard of mounted lancers and was preceded through the city by the captains of police in handsome uniforms, ridaing black horses. Several regiments of trcops were drawn up in line on either side of the streets through which he passed, to keeps back the crowd which was very large. Everything was well arranged so that there was no noise, no cheering, no confusion. The people did not prostrate themselves but merely put down their umbrellas and uncovered their heads as his majesty 
passed by ${ }^{278}$

${ }^{278}$ William Smith Clark to Mrs. Harriet Clark, July, 23, 1876 . 
APPENDIX D

COURSE LIST AT THE SAPPORO AGRICULTURAL COLLEGE 
COURSE LIST AT THE SAPPORO AGRICULTURAL COLLEGE

Freshman Year
First Term: Algebra, including Logarithms, 6 hours each week; Chemistry Physics and Inorganic Chemistry, 6 hours; English, 6 hours; Japanese, 4 hours; Military Drill, 2 hours; Manual Labor, 6 hours.

Second Term: Geometry and Conic sections, 6 hours each week; Organic and Practical Chemistry, 8 hours; Agriculture, 4 hours; English, 2 hours; Elocution, 2 hours; Freehand and Geometrical Drawing, 3 hours; Military Drill, 2 hours; Manual Labor, 6 hours.

\section{Sophomore Year}

First Term: Agricultural and Analytical Chemistry, 8 hours each week; Botany, 3 hours; Human Anatomy and Physiology, 3 hours; English, 2 hours; Elocution, 2 hours; Agriculture, 4 hours; Military Drill, 2 hours; Manual Labor, 6 hours.

Second Term: Trigonometry and Surveying, 5 hours each week; Quantitative Analytical Chemistry, 8 hours; Botany, 4 hours; Agriculture, 2 hours; English and Japanese Translation, 2 hours; Mathematical Drawing and Plotting, 3 hours; Military Drill, 2 hours; Manual Labor, 3 hours.

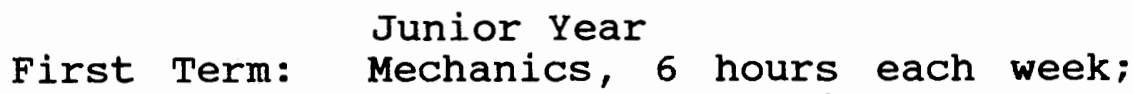
Zoology, 3 hours; Botany, 3 hours; Fruit Culture, 3 hours; English, 4 hours; Japanese, 2 hours; Military Drill, 2 hours; Manual Labor as required. Second Term: Astronomy and Topography, 6 hours each week; Stock and Dairy Farming, 3 hours; History of English Literature, 6 hours; Landscape Gardening, 3 hours; English and Japanese Compositions and Translations, 2 hours; Military Drill, 2 hours; Mechanical and Topographical Drawing, 3 hours.

\section{Senior Year}

First Term: Physics, 6 hours each week; Veterinary Science and Practice, 6 hours; Geology, 4 hours; Book-keeping, 4 hours; Extempore Debate, 2 hours; Microscopy, 3 hours; Military Drill, 2 hours. 
Second Term: Roads, Railroads, and Hydraulic Engineering, 6 hours each week; Mental Science, 4 hours: Political Economy, 4 hours; Original Declamations, 1 hour, Military Drill, 2 hours. ${ }^{279}$

279 Hokkaido Imperial University, The Semi-Centennial, p. 13. 
APPENDIX E

CHARTER OF THE KAISHIKISHA 
CHARTER OF THE KAISHIKISHA

Article 1. The name of this society shall be
kaishikisha, and its object shall be the
improvement in writing, and speaking of its
members. Article 2. The officers of the society shall be a President a Vice-president and a secretary who shall be treasurer. These three officers shall also constitute the Executive committee of the society. They shall be elected by ballot at the last regular meeting of each college term and shall hold office during the next succeeding term or until their successors are chosen.

Article 3. It shall be the duty of these officers individually to perform the work usually devolving upon such officers in their respective positions as laid down in Gresting's Manual of Parliamentary Law. As a committee they shall arrange and transact the business of the society according to their best ability as instructed by votes or directed in the constitution and By Laws.

Article 4. The literary exercises of the society shall be conducted in the English and Japanese languages as directed by the Executive committee in assigning the appointments, and shall consist of Readings, Declamations, Compositions, and Debates. A critic shall be appointed for each meeting who shall criticize the proceedings and performances at the close of the session. The appointments for each meeting shall be prepared by the Executive Committee at least three weeks beforehand, when practicable, and announced by the secretary at regular meetings...

Article 5. The meetings of the society shall be held every saturday evening, beginning at 7 o'clock.

Article 6. Any member of the Sapporo Agricultural College may become a member of the society by signing his name to this constitution, but may be expelled by a vote of two-thirds of the members present at any regularly called meeting for negligence of duty or improper conduct.

Article 7. This Constitution and these By Laws may be amended by a vote of two thirds of the members present at any regular meeting of the society, provided the proposed amendments have been read 
once at some previous meeting of the same. ${ }^{280}$

280 Constitution and By Laws of the Kaishikisha, by william Smith Clark, 1876, william S. Clark Collection, Archives and Manuscripts Department University Library, University of Massachusetts at Amherst. 
APPENDIX F

CHARTER OF THE COVENANT OF BELIEVERS IN JESUS 
CHARTER OF THE COVENANT OF BELIEVERS IN JESUS

The undersigned, members of the Sapporo Agricultural College, desiring to confess christ according to his command, and to perform with true fidelity every Christian duty in order to show our love and gratitude for that blessed Savior who has made atonement for our sins by his death on the cross; and earnestly wishing to advance his kingdom among men for the promotion of his glory and the salvation of those for whom he died, do solemnly covenant with God and with each other from this time forth to be his faithful disciples, and to live in strict compliance with the letter and the spirit of his teachings; and whenever a suitable opportunity offers we promise to present ourselves for examination, baptism, and admission to some evangelical church.

We believe the Bible to be the only direct revelation in language from God to man and the only perfect and infallible guide to a glorious future life.

We believe in one, ever living God who is our merciful Creator, our just and sovereign Ruler, who is to be our final judge.

We believe that all who sincerely repent and by faith in the Son of God obtain the forgiveness of their sins will be graciously guided through this life by the holy spirit and protected by the watchful providence of the Heavenly Father, and so at length prepared for the enjoyments and pursuits of the redeemed and holy ones; but that all who refuse to accept the invitations of the Gospel must perish in their sins and be forever banished from the presence of the Lord.

The following commandments we promise to remember and obey through all the vicissitudes of our earthly lives.

Thou shalt love the Lord thy God with all thy heart, and with all thy soul, and with all thy strength, and with all thy mind; and thy neighbor as thyself.

Thou shalt not worship any graven image or any likeness of any created being or thing.

Thou shalt not take the name of the Lord thy God in vain.

Remember the Sabbath day to keep it holy, avoiding all unnecessary labor, and devoting it as 
far as possible to the study of the Bible and the preparation of thyself and others for holy life. rulers. Thou shalt obey and honor thy parents and

Thou shalt not commit murder, adultery or any other impurity, theft or deception.

Thou shalt not do evil to thy neighbor.

Pray without ceasing.

For mutual assistance and encouragement we hereby constitute ourselves an association under the name "Believers in Jesus," and we promise faithfully to attend one or more meetings each week while living together for the reading of the Bible or other religious books or papers, for conference and for social prayer; and we sincerely desire the manifest presence in our hearts of the Holy spirit to quicken our love, to strengthen our faith, and to guide us into a saving knowledge of the truth. ${ }^{281}$ 


\section{APPENDIX G}

LETTER FROM THE LEGATION OF JAPAN PETITIONING CLARK TO LECTURE AGAINST THE UNEQUAL TREATIES 
LETTER FROM THE LEGATION OF JAPAN PETITIONING CLARK TO LECTURE AGAINST THE UNEQUAL TREATIES

It should be remembered that the convention was signed, on the part of the U.S. by a young and inexperienced diplomat, while the English part of the business was conducted by a man of experience and sagacity. The result was that England managed to fasten her free trade doctrines on Japan, secured a monopoly of the Japanese trade, and is now the one party which will suffer most by the abrogation of the aforesaid convention. on the other the United states is receiving no special benefit from the Convention, and yet by postponing an equitable revision, it is in reality helping England at the expense of Japan. Surely it can only be necessary for the people and Government of the United States to understand the true status of this business - to united and consent, and even insist, upon a more equitable arrangement. We hear a great deal from washington about the importance of extending American trade with foreign nations, and here is a case, in which by acting promptly and justly, our government can not only greatly increase the commerce of the country, but at the same time prove that we are the real friends of Japan. It is about time that, after preaching about Christian civilization for so many years, that our Government should at least do one act which will be in keeping with our professions.

Now that the Satsuma Rebellion has been subdued, the material interests of Japan are attracting the special attention of the government and people. They are getting restless under the wrongs, fastened upon them by Foreign cupidity and intrigue, and the press of the country is commenting upon the unhappy state of affairs in no measured terms. One of the native journals for example, uses this language: "Our rights have been given away to Englishmen, and yet they are not satisfied, and are filled with anger, hate and disdain." In proof of this, the reader has only to look in the columns of the "Herald" and "Mail" which are the domineering organs of the British Government in Japan. Another native paper makes this remark: "Japan holds and equal grade with other nations, so they should give us our due. But 
from selfish motives they are not anxious to change the terms of the treaties. Why do our people delay so long?" Again: "Though our nation is small, poor and weak, our intercourse with distant governments has been very friendly. For these reasons, we can see no justification for any interference with our condition of independence." Another writer makes this significant remark: "We have never heard that a nation which is not on an equality on matters of commerce with others, can avoid becoming poverty stricken"; and other opinions are to this effect: "Foreigners have taken away our rights and we have fallen into a very great misfortune; our rights have been invaded and we have suffered great wrong; for the treatment we have endured, we have been in our hearts to hate Englishmen and strangers generally: the Japanese are very earnest in their efforts for improvement in civilization, but they find their way blocked up; we would distinctively declare our conviction that we certainly cannot long continue to stand by the present treaties, because they are unjust to us, and disgraceful to the English themselves."

There is no disguising the fact that the feeling of the Japanese against England is very bitter, because they look upon her as the one great power that is getting rich at their expense; it is to be hoped that the United States will not consent any longer to uphold England in her grasping policy on the other side of the Pacific.

Let us remember that the injustice which we suffered, when our forefathers threw the tea into Boston Harbor, came from the same grasping spirit that is now dominating Japan.

Let us remember also these things:

That Japan excelled all other nations in glorifying our International Exhibitions by the beauty of her products;

That, as she made her first treaty with the United states, it is our duty to treat her as a friend, to the last extremity, and, as bearing upon this point, the following clause from the II Article of the treaty of 1858, may be noted: "The President of the United States, at the request of the Japanese Government, will act as a friendly mediator in such matters of difference, as may arise between the Government of Japan and any European Power."

That when she concluded to send her children abroad to be educated, she sent the majority of them to this country;

That when she wanted men of learning and 
science to help her in her new career, she invited Americans to her shore, and paid them with a most liberal hand; and finally let us remember that it becomes a proud and independent government, as well as every honest man, to do the right thing in every emergency, and that too with the utmost promptness. ${ }^{282}$

282 The Legation of Japan in Washington to Professor Clark, January 14,1878 . 